\title{
Júlia Martins
}

Desenvolvimento de métodos miniaturizados de extração em fase sólida para a pré-concentração de produtos de degradação de fluoroquinolonas e sulfonamidas em matrizes aquosas

Dissertação de mestrado apresentada ao Instituto de Química de São Carlos da Universidade de São Paulo como parte dos requisitos para a obtenção do título de mestre em ciências.

Área de concentração: Química Analítica e Inorgânica

Orientador: Prof. Dr. Álvaro José dos Santos Neto

\section{EXEMPLAR REVISADO}

O exemplar original encontra-se em acervo reservado na Biblioteca do IQSC-USP

São Carlos 


\title{
DEDICATÓRIA
}

\author{
À minha mãe Henriqueta, \\ Por sempre acreditar em mim, \\ Pelas injeções de coragem quando essa me faltava, \\ Por todas as batalhas que já travamos juntas \\ E pelas vitórias que conseguimos. \\ Por sempre estar por perto, \\ Mesmo que fisicamente distante. \\ És uma guerreira e és meu orgulho! \\ Esse trabalho é um dos frutos que colho \\ Das sementes que plantaste. \\ Muito obrigada por tudo!
}




\section{AGRADECIMENTOS}

Agradeço primeiramente a Deus, por me dar a oportunidade de estar aqui, poder realizar meus objetivos e continuar traçando minha trajetória.

À minha mãe, Henriqueta, por toda a força, coragem, palavras de apoio e pelo amor incondicional. Por entender nossa distância, apenas física, e nunca se fazer ausente.

A meu pai, Sergio, e minha madrasta, Mharli, por toda a acolhida, conselhos, conversas e por sempre acreditarem em mim e no meu potencial.

Aos meus avós, Ruth e Bento, que desde muito cedo me ensinaram o valor do estudo e me apoiam aonde quer que eu vá.

A meu orientador, Prof. Dr. Álvaro José dos Santos Neto, pela confiança em meu trabalho, por todo o apoio e orientações que foram essenciais para este trabalho e em minha formação. Além de seu talento para a pesquisa, sua humildade e dedicação o tornam mais que um orientador, um amigo.

Ao Laboratório de Cromatografia por toda a infraestrutura disponibilizada para o desenvolvimento deste trabalho.

À Dra. Tanare Cambraia, por todo o apoio, conversas e ensinamentos que adicionaram muito a este trabalho e a mim como pessoa e pesquisadora.

Aos meus caríssimos colegas do Laboratório de Cromatografia, que sempre atenderam prontamente aos meus chamados, telefonemas e pedidos de ajuda. E também proporcionaram muitas risadas, cafés e momentos de descontração. Vocês foram parte essencial deste trabalho, me acolheram prontamente e fizeram desses dois anos mais que especiais. Sempre os levarei comigo!

Ao pessoal da secretaria de pós-graduação, Andreia, Sílvia e Gustavo, por toda a disposição em sanar dúvidas e ajudar.

À FAPESP pela concessão da bolsa de mestrado (Processo 2013/06415-8).

À Dra. Fernanda Z. Leandro, por ter me apadrinhado desde os tempos de iniciação científica, por sempre acreditar em minha capacidade e me mostrar que a ciência deve ser feita com ética, paciência, muito trabalho, mas também com paixão. Por todas as nossas 
conversas e por falar muitas vezes o que eu não queria ouvir. Você é um exemplo profissional e de vida.

Aos "Caras" mais especiais que conheço, Camila, Maísa, Renan e João, vocês me acompanham desde a graduação e a cada reencontro, parece que o tempo não passou. Espero que seja sempre assim.

À Milena Krieck Farche, por ter feito uma convivência de seis meses virar uma amizade de seis anos, apesar da distância. Espero que acompanhemos a trajetória e as vitórias uma da outra sempre.

À Amanda e Lidiane, pela amizade duradoura, por entenderem minha ausência e estarem sempre de braços abertos para me receber e me ouvir. 
"Evoluir é variar e só se varia por meio da invenção.

Os homens imitativos limitam-se a cumular as conquistas dos originais.

A utilidade do rotineiro está subordinada à existência do idealista, como a fortuna dos livreiros depende do talento dos escritores."

(José Ingenieros) 


\section{RESUMO}

A presença de antibióticos em águas superficiais e subterrâneas é motivo de preocupação, devido ao surgimento de bactérias resistentes. Contudo, a maioria dos trabalhos publicados na literatura científica mantém o foco nos antibióticos inalterados, sendo que as moléculas degradadas também estão no ambiente. Esses produtos de degradação podem ser tão ou mais prejudiciais do que as moléculas que lhes deram origem. Esse trabalho teve por objetivo desenvolver métodos de extração utilizando a microextração por sorvente empacotado (MEPS) para pré-concentrar e recuperar produtos de fotodegradação de representantes das sulfonamidas (sulfametazina) e fluoroquinlonas (ciprofloxacino), duas das mais importantes classes de antibióticos. MEPS é considerada uma técnica promissora utilizando pequenos volumes de amostra e de solventes, além de empregar pequenas quantidades de fase extratora, que ainda pode ser reutilizada. Foram comparadas as fases Oasis ${ }^{\circledR}$ HLB e nanotubos de carbono, sendo que a primeira apresentou melhores resultados. Seis produtos de degradação da sulfametazina (SMZ) e oito produtos do ciprofloxacino (CIP), além das moléculas inalteradas, foram pré-concentrados e analisados por cromatografia líquida acoplada à espectrometria de massas de alta resolução (LC-ESI-ToF). Inicialmente, as concentrações de fármaco inalterado utilizadas na fotodegradação foram de $25 \mathrm{mg} \mathrm{L}^{-1}$ (SMZ) e $10 \mathrm{mg} \mathrm{L}^{-1}$ (CIP), para que os produtos fossem identificados. As taxas de recuperação por MEPS ficaram acima de 50\%, o que é um resultado promissor, considerando-se as diferenças estruturais dos produtos de degradação. Em concentrações 100 vezes menores, MEPS conseguiu préconcentrar todos os produtos da SMZ e do CIP, facilitando sua detecção. Após desenvolver a pré-concentração por MEPS em água purificada, foram realizados estudos de efeito de matriz em esgoto sintético. Enquanto somente um produto de degradação da SMZ sofreu supressão de ionização, todos os outros (inclusive os de CIP) experimentaram um aumento de sinal devido à presença dos interferentes de matriz. O método desenvolvido para MEPS também foi testado para pré-concentrar produtos de degradação anaeróbica da SMZ em reator biológico, obtendo-se êxito. Dessa forma, MEPS desponta como uma técnica promissora para préconcentrar produtos de degradação e para que pesquisadores possam acompanhar a degradação de reatores biológicos, visto que requer pequenas quantidades de amostra, não alterando significativamente o volume do meio reacional. 


\begin{abstract}
Antibiotics are present both surface water and groundwater and this is motive of concern, due to their ability to cause bacterial resistance. Nevertheless, most of publications in scientific area focuses in unchanged compounds, even knowing the presence of degraded molecules in the environment. These degradation products might be so or more dangerous than unchanged compounds. In this work, extraction methods for degradation products were developed using microextraction by packed sorbent (MEPS). MEPS is an eco-friendly technique due to little consumption of sample, solvents and sorbent. The degradation products of sulfamethazine (SMZ) and ciprofloxacin (CIP) were generated by photodegradation at $25 \mathrm{mg} \mathrm{L}^{-1}$ and $10 \mathrm{mg} \mathrm{L}^{-1}$ of unchanged drug, respectively. The number of degradation products was six for SMZ and eight for CIP. Oasis ${ }^{\circledR}$ HLB and carbon nanotubes were tested as sorbents and the first got better results in preconcentration. The chromatographic analysis was performed by liquid chromatography coupled to high resolution mass spectrometry (LC-ESI-ToF). Recovery rates obtained by MEPS were greater than $50 \%$, which is a significant result, considering structural differences among degradation products. After setting extraction conditions, MEPS was able to recover degradation products at concentrations 100 times lower and more akin to those find in the environment. Using synthetic sewage as medium, matrix effect studies were performed. The prevalent effect was an increase of ionization in degradation products (both SMZ and CIP), just one SMZ product experienced suppression of ionization. At last, SMZ was degraded in an anaerobic reactor and the degradation products were preconcentrated by MEPS. Although the biological degradation products were not the same of photodegradation (except by one), MEPS was capable to preconcentrate them. Thereby, MEPS starts to dawn as a promising technique to preconcentrate degradation products, specially for researchers using biological reactors, since MEPS requires low volumes of sample and almost do not change the final bulk of reactor.
\end{abstract}




\section{LISTA DE FIGURAS}

Figura 1 - Possibilidades de metabolização comumente reportadas para sulfonamidas. Em cinza, reações de oxi-redução e em branco, reações de conjugação.

Figura 2 - Microsseringa MEPS $(250 \mu \mathrm{L})$ e dispositivo de extração com material sorvente empacotado.

Figura 3 - Ilustração das etapas do processo MEPS .29

Figura 4 - Reator Acoplado ao Sistema de Recirculação. 37

Figura 5 - Espectro da lâmpada de Hg utilizada na fotodegradação da SMZ. 38

Figura 6 - Comparação analítica entre Controle, representante do Grupo I, Grupo II, Grupo III e Grupo IV referente à otimização do número de ciclos em MEPS.

Figura 7 - Etapas da extração dos produtos de degradação da sulfametazina.

Figura 8 - Cromatograma (íon extraído) do intermediário m/z 229 encontrados durante a fotólise da SMZ (0,25 mg L-1) e sua estrutura proposta. . .52

Figura 9 - Cromatograma do íon total referente à recuperação por MEPS dos produtos de degradação da sulfametazina em baixa concentração $\left(0,25 \mathrm{mg} \mathrm{L}^{-1}\right)$. Em vermelho, produtos de degradação antes da extração. Em azul, produtos de degradação após a extração. 52

Figura 10 - Cromatograma do íon total referente à recuperação por MEPS dos produtos de degradação da sulfametazina em baixa concentração $\left(0,25 \mathrm{mg} \mathrm{L}^{-1}\right)$ em esgoto sintético. Em vermelho, produtos de degradação que não passaram por extração. Em azul, produtos de degradação após a extração. .55

Figura 11 - Cromatograma do íon total referente à recuperação por MEPS dos produtos de degradação da sulfametazina em alta concentração $\left(25 \mathrm{mg} \mathrm{L}^{-1}\right)$ em água, utilizando nanotubos de carbono como fase extratora. Em vermelho, produtos de degradação que não passaram por extração. Em magenta, alíquota residual após passar por extração. Em azul, produtos de degradação após a extração. Em verde, fase extratora após lavagem. .59

Figura 12 - Produtos de degradação encontrados durante a biodegradação da SMZ obtidas a partir de análises realizadas por LC-QTOF (ESI (+) MS) após 72 horas de exposição ao reator anaeróbio. 1) Metabólito hidroxilado da SMZ; 2) SMZ inalterada e 3) conjugação com glicose 
Figura 13 - Cromatograma do íon total referente à recuperação por MEPS dos produtos de degradação do ciprofloxacino em baixa concentração $\left(0,10 \mathrm{mg} \mathrm{L}^{-1}\right)$. Em vermelho, produtos de degradação antes da extração. Em azul, produtos de degradação após a extração.

Figura 14 - Cromatograma do íon total referente à recuperação por MEPS dos produtos de degradação do ciprofloxacino em baixa concentração $\left(0,10 \mathrm{mg} \mathrm{L}^{-1}\right)$ em esgoto sintético. Em vermelho, produtos de degradação que não passaram por extração. Em azul, produtos de degradação após a extração. .70

Figura 15 - Cromatograma do íon total referente à recuperação por MEPS dos produtos de degradação do ciprofloxacino em alta concentração $\left(10 \mathrm{mg} \mathrm{L}^{-1}\right)$ em água, utilizando nanotubos de carbono como fase extratora. Em vermelho, produtos de degradação que não passaram por extração. Em magenta, alíquota residual após passar por extração. Em azul, produtos de degradação após a extração. Em verde, fase extratora após lavagem. 


\section{LISTA DE TABELAS}

Tabela 1 - Concentração $\left(\mu \mathrm{g} \mathrm{L}^{-1}\right)$ de antibióticos em afluentes e efluentes de estações de tratamento europeias

Tabela 2 - Comparações de parâmetros entre as técnicas MEPS, SPE e SPME

Tabela 3 - Cartuchos e solventes avaliados na pré-concentração dos produtos de degradação da sulfametazina.

Tabela 4 - Experimentos para otimizar os ciclos de extração da amostra e os ciclos de eluição dos compostos de interesse.

Tabela 5 - Estruturas químicas propostas para os produtos de degradação da sulfametazina obtidos pela fotólise.

Tabela 6 - Eficiência relativa (\%) do número de ciclos de extração e eluição em MEPS para extrair produtos de degradação da sulfametazina.

Tabela 7 - Pré-concentração dos produtos de degradação de sulfametazina em água, com diluição de 1:20.

Tabela 8 - Pré-concentração dos produtos de degradação da sulfametazina utilizando 5 ciclos de lavagem.

Tabela 9 - Pré-concentração dos produtos de degradação da sulfametazina utilizando 3 ciclos de lavagem.

Tabela 10 - Pré-concentração dos produtos de degradação de sulfametazina em esgoto sintético, com diluição de 1:20.

Tabela 11 - Efeito de matriz, recuperação e eficiência do processo para produtos de degradação da sulfametazina em esgoto sintético.

Tabela 12 - Pré-concentração dos produtos de degradação de sulfametazina utilizando nanotubos de carbono como fase extratora, com diluição 1:20. .58

Tabela 13 - Pré-concentração dos produtos de degradação de sulfametazina (com diluição 1:20) utilizando etanol como solvente em substituição ao metanol.

Tabela 14 - Presença de produtos de degradação da sulfametazina no efluente de reator biológico.

Tabela 15 - Estruturas químicas, relações massa/carga e fórmula molecular do ciprofloxacino e seus produtos de degradação

Tabela 16 - Pré-concentração dos produtos de degradação do ciprofloxacino em água, com diluição de 1:20. 
Tabela 17 - Pré-concentração dos produtos de degradação do ciprofloxacino em esgoto sintético, com diluição de 1:20.

Tabela 18 - Efeito de matriz, recuperação e eficiência do processo para produtos de degradação do ciprofloxacino em esgoto sintético .71

Tabela 19 - Pré-concentração dos produtos de degradação de ciprofloxacino utilizando nanotubos de carbono como fase extratora, com diluição 1:20. 


\section{LISTA DE ABREVIATURAS E SIGLAS}

ETE - Estação de Tratamento de Esgoto

FQ - Fluoroquinolona

FDA - Food and Drug Administration

$\mathrm{SF}$ - Sulfonamida

PABA - Ácido para-aminobenzóico

UV - Radiação ultravioleta

LC - Cromatografia líquida

LOD - Limite de detecção

LOQ - Limite de quantificação

MS - Espectrometria de massas

SPE - Extração em fase sólida

SPME - Microextração em fase sólida

MEPS - Microextração por sorvente empacotado

GC - Cromatografia gasosa

BIN - Barrel insert and needle

RAM - Materiais de acesso restrito

MIP - Polímeros molecularmente impressos

LC-MS - Cromatografia líquida acoplada à espectrometria de massas

API - Ionização à pressão ambiente

APCI - Ionização química à pressão ambiente

ESI - Ionização por electrospray

m/z - Relação massa/carga

ME - Efeito de matriz

RE - Recuperação dos analitos

PE - Eficiência de processo

SMZ - Sulfametazina

CIP - Ciprofloxacino

$\mathrm{MeOH}-\mathrm{Metanol}$ 
$\mathrm{ACN}$ - Acetonitrila

HPLC - Cromatografia líquida de alta eficiência

MWCNT - Nanotubo de carbono de múltiplas paredes

CV - Coeficiente de variação

Rec - Recuperação obtida na pré-concentração dos analitos de interesse

EPA - United States Environmental Protection Agency 


\section{SUMÁRIO}

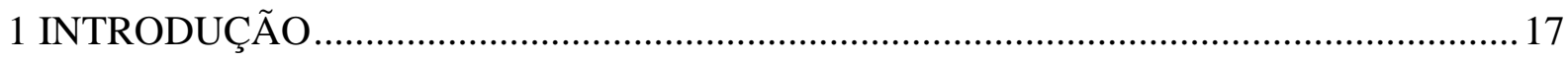

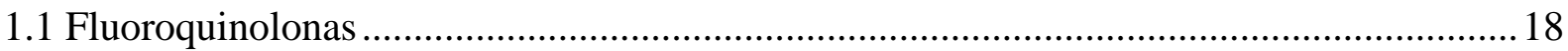

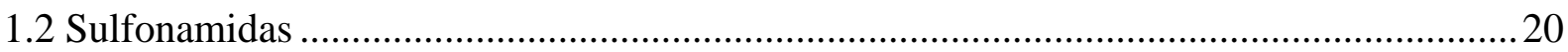

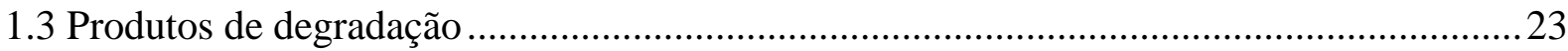

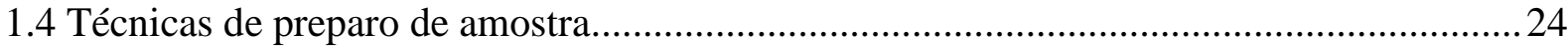

1.4.1 Microextração por sorvente empacotado (MEPS)....................................25

1.5 Cromatografia líquida de alta eficiência acoplada à espectrometria de massas (LC-MS) 29

1.5.1 Efeitos de matriz em espectrometria de massas ...........................................33

1.6 Fotodegradação por radiação ultravioleta (UV) ............................................................ 34

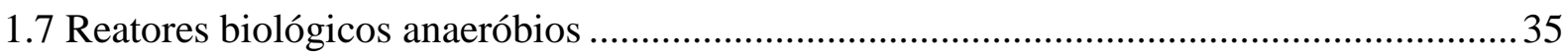

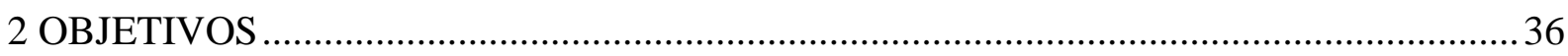

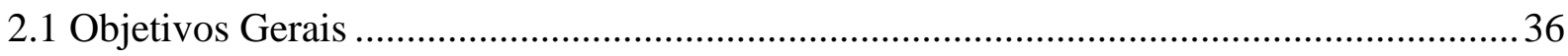

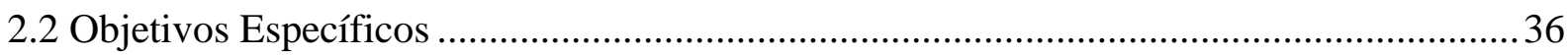

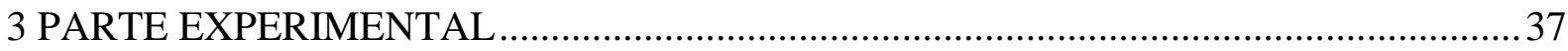

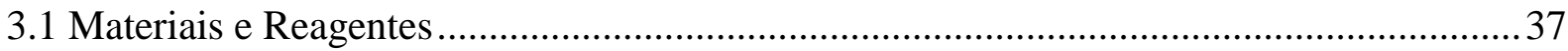

3.2 Degradação da sulfametazina por fotólise em meio neutro................................................37

3.3 Escolha da melhor fase extratora e eluente para os produtos de degradação da

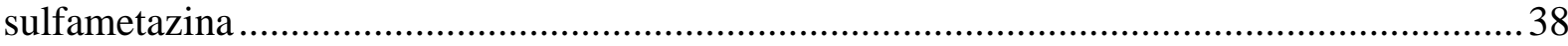

3.4 Otimização da extração de produtos de degradação da sulfametazina utilizando

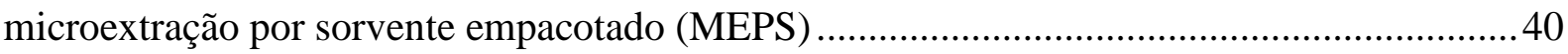

3.5 Pré-concentração dos produtos de degradação da sulfametazina em água ........................ 40

3.6 Degradação da sulfametazina em baixa concentração ................................................... 40

3.7 Pré-concentração dos produtos de degradação da sulfametazina em esgoto sintético ....... 40

3.8 Otimização das etapas de lavagem em MEPS ................................................................ 41

3.9 Estudos de efeitos de matriz com produtos de degradação da sulfametazina .................... 41 
3.10 Degradação da sulfametazina em baixa concentração utilizando esgoto sintético como matriz

3.11 Avaliação de nanotubos de carbono como sorvente para produtos de degradação da sulfametazina

3.12 Avaliação de etanol absoluto como substituto do metanol na extração dos produtos de degradação da sulfametazina

3.13 Análise de produtos de degradação da sulfametazina em reator biológico

3.14 Ciprofloxacino

4.1 Avaliação dos produtos de degradação formados durante a fotólise da sulfametazina na concentração de $25 \mathrm{mg} \mathrm{L}^{-1}$

4.2 Otimização da extração de produtos de degradação da sulfametazina por MEPS

4.3 Pré-concentração dos produtos de degradação da sulfametazina em água

4.4 Pré-concentração dos produtos de degradação da sulfametazina em baixa concentração .51

4.5 Otimização da lavagem em MEPS para extração de produtos de degradação em matrizes complexas .....

4.6 Pré-concentração dos produtos de degradação da sulfametazina em esgoto sintético .......54

4.7 Pré-concentração dos produtos de degradação da sulfametazina em baixa concentração utilizando esgoto sintético como matriz

4.8 Estudos de efeitos de matriz na análise de produtos de degradação da sulfametazina .......56

4.9 Pré-concentração dos produtos de degradação da sulfametazina utilizando nanotubos de

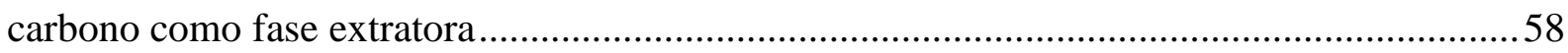

4.10 Pré-concentração dos produtos de degradação da sulfametazina substituindo metanol por etanol anidro

4.11 Análise dos intermediários de sulfametazina em efluente de reator biológico

4.12 Avaliação dos produtos de degradação formados durante a fotólise do ciprofloxacino na concentração de $10 \mathrm{mg} \mathrm{L}^{-1}$ 
4.13 Pré-concentração dos produtos de degradação do ciprofloxacino, com diluição 1:20, em água

4.14 Pré-concentração dos produtos de degradação do ciprofloxacino em baixa concentração

4.15 Pré-concentração dos produtos de degradação do ciprofloxacino, com diluição de 1:20 em esgoto sintético

4.16 Pré-concentração dos produtos de degradação do ciprofloxacino em baixa concentração utilizando esgoto sintético como matriz

4.17 Estudos de efeitos de matriz na análise de produtos de degradação do ciprofloxacino ...70 4.18 Pré-concentração dos produtos de degradação do ciprofloxacino utilizando nanotubos de carbono como fase extratora 72

5 CONCLUSÕES 75

6 REFERÊNCIAS BIBLIOGRÁFICAS 77 


\section{INTRODUÇÃO}

O monitoramento de fármacos residuais no meio ambiente vem ganhando interesse devido ao fato de muitas dessas substâncias serem frequentemente encontradas em efluentes de Estações de Tratamento de Esgoto (ETE) e águas naturais, em concentrações na faixa de $n g \mathrm{~L}^{-1}$ a $\mu \mathrm{g} \mathrm{L}^{-1}$. Stumpf e colaboradores ${ }^{1}$ relataram em seu estudo que a presença de fármacos residuais em águas superficiais pode ser um indicativo de contaminação por esgoto das ETE.

Estudos demonstram que várias dessas substâncias parecem ser persistentes no ambiente e não são completamente removidas nas $\mathrm{ETE}^{1-3}$. Sendo assim, muitos fármacos residuais resistem a vários processos de tratamento convencional de água.

Os fármacos são desenvolvidos para serem (em sua maioria) estáveis, mantendo suas propriedades químicas inalteradas para servir a um propósito terapêutico. Assim, em muitos casos uma fração significativa da dose ingerida do fármaco é excretada inalterada e persiste no ambiente ${ }^{4}$. O uso desenfreado de antibióticos acarreta a contaminação dos recursos hídricos e o consequente potencial de desenvolverem-se microrganismos com resistência a esses fármacos.

Alguns grupos de fármacos residuais merecem uma atenção especial, dentre eles estão os já mencionados antibióticos e os estrogênios ${ }^{4}$. Os antibióticos têm sido extensivamente discutidos na literatura científica, devido ao seu potencial de desenvolvimento de bactérias resistentes no meio ambiente. Há indícios de que o desenvolvimento de resistência antibiótica possa ser favorecido por baixas concentrações desses compostos no meio ambiente, ${ }^{5-9}$ e por serem usados amplamente, tanto na medicina humana, quanto na medicina veterinária (crescimento do gado, aquicultura e produção avícola e suína) ${ }^{10-12}$. Alguns autores, como Barceló $^{13}$, chamam os antibióticos de fármacos pseudo-persistentes, já que a dificuldade de degradação muitas vezes não é o maior empecilho, mas sim a grande quantidade em que esses fármacos chegam às águas superficiais diariamente, tanto pela excreção dos seres vivos quanto pelo descarte das indústrias farmacêuticas e de outras atividades produtivas.

A presença desses fármacos residuais na água pode causar efeitos adversos na saúde, seja humana ou de outros organismos presentes nas águas, como os peixes. Por isso, existe uma preocupação crescente no desenvolvimento de métodos analíticos suficientemente sensíveis para a determinação dos fármacos residuais em ambientes aquáticos, com limites de detecção na ordem de $\mu \mathrm{g} \mathrm{L}^{-1}$ a ng $\mathrm{L}^{-1}{ }^{14-16}$. 
No Brasil, um estudo demonstrou a presença de todos os oito antibióticos avaliados na bacia do rio Atibaia, região de Campinas. A maior parte dos fármacos encontrados teve concentrações na ordem de ng $\mathrm{L}^{-1}$ ou menos, no entanto a região com maior atividade antropogênica chegou a apresentar contaminações de 1,3 e $2,4 \mu \mathrm{g} \mathrm{L^{-1 }}$ para dois dos antibióticos ${ }^{17}$.

Em um estudo publicado em $2011^{18}$ foi feita uma compilação de 45 publicações entre 1997 e 2010 relatando a concentração de diversas classes de fármacos em afluentes (esgoto bruto, antes do tratamento) e efluentes (esgoto tratado) de diversos lugares da Europa. As ETE possuíam tratamento primário, secundário (lodo ativado) e, às vezes, terciário. $\mathrm{Na}$ Tabela 1 estão expostos somente os antibióticos, que são a classe de fármacos estudada nesse trabalho.

Tabela 1 - Concentração $\left(\mu \mathrm{g} \mathrm{L}^{-1}\right)$ de antibióticos em afluentes e efluentes de estações de tratamento europeias

\begin{tabular}{lccccccccc}
\hline \multirow{2}{*}{ Moléculas } & \multicolumn{9}{c}{ Afluente } \\
\cline { 2 - 10 } & Conc & Mín & Máx & $\mathrm{n}$ & Conc & Mín & Máx & $\mathrm{N}$ & $\begin{array}{c}\% \\
\text { Remoção }\end{array}$ \\
\hline Ciprofloxacino & 0,62 & 0,09 & 5,524 & 13 & 0,234 & 0,007 & 2,378 & 13 & 62,3 \\
Doxiciclina & 0,65 & 0,067 & 2,48 & 10 & 0,42 & 0,038 & 1,09 & 9 & 35,4 \\
Eritromicina & 0,58 & 0,346 & 0,83 & 3 & 0,297 & 0,109 & 0,62 & 4 & 48,8 \\
Norfloxacino & 0,115 & 0,066 & 0,25 & 12 & 0,053 & 0,007 & 0,33 & 10 & 54,3 \\
Ofloxacino & 0,482 & 0,007 & 2,275 & 6 & 0,171 & 0,007 & 0,816 & 6 & 64,5 \\
Roxitromicina & 0,78 & 0,027 & 1,50 & 3 & 0,472 & 0,008 & 0,087 & 3 & 39,5 \\
Sulfametoxazol & 0,32 & 0,02 & 0,674 & 10 & 0,264 & 0,07 & 0,62 & 11 & 17,5 \\
Trimetoprim & 0,43 & 0,053 & 1,3 & 15 & 0,424 & 0,04 & 1,34 & 17 & 1,4 \\
\hline *Conc = concentração média; Mín= concentração mínima; Máx = cocnetração máxima; n= número de artigos \\
nos quais o fármaco apareceu.
\end{tabular}

Fonte: adaptado de DEBLONDE, T. Int. J. Hyg. Envir. Heal., v. 214, p. 444, $2011^{18}$.

Na Tabela 1 fica exposto o quanto tratamentos de efluentes atuais são ineficientes para eliminar antibióticos. Nenhum dos artigos registrou remoção acima de $65 \%$ e, no caso do trimetoprim, a remoção foi inferior a $2 \%$.

\subsection{Fluoroquinolonas}

As fluoroquinolonas (FQs) são derivadas dos antibióticos quinolônicos, que tiveram como seu protótipo o ácido nalidíxico, sintetizado e patenteado em 1962 por Lescher e colaboradores. Na década de 1970 foram feitas sínteses introduzindo no anel quinolônico um átomo de flúor em posição $\mathrm{C} 6$ e um grupo piperazila em posição $\mathrm{C} 7$, dando origem às fluoroquinolonas ${ }^{19}$. Essa combinação levou a um maior espectro de ação e a um aumento da 
capacidade das quinolonas penetrarem na parede bacteriana levando, consequentemente, a uma melhor atividade contra bactérias Gram-negativas, passando a abranger algumas espécies Gram-positivas. As fluoroquinolonas atingiram também um perfil farmacocinético melhor, chegando a ter uma atividade antibacteriana mil vezes superior àquela observada pelo ácido nalidíxico, seu antecessor ${ }^{20}$. Os principais representantes desse grupo são o enrofloxacino, norfloxacino, ciprofloxacino, ofloxacino, levofloxacino e perfloxacino.

A presença de um grupo ácido (grupo carboxílico) e de um grupo básico (amina terciária) atribui ao composto propriedades anfotéricas podendo, deste modo, existir mais do que uma espécie presente em solução, dependendo do $\mathrm{pH}$. Devido à protonação/desprotonação dos grupos, há influência no comportamento farmacológico destes compostos, uma vez que a presença de grupos carregados é necessária para a atividade biológica $^{21}$. Dependendo do $\mathrm{pH}$ em que se encontra o meio, as quinolonas podem existir sob as formas catiônica, aniônica, neutra ou de íon dipolar. No pH 7,4 (fisiológico) as quinolonas encontram-se total ou parcialmente ionizadas sendo a espécie predominante a forma de íon dipolar podendo, no entanto, coexistir com as formas aniônica e catiônica ${ }^{21}$.

Segundo dados da literatura ${ }^{20}$, o enrofloxacino em $\mathrm{pH} 7,4$, encontra-se $92 \%$ na forma de íon dipolar, $4 \%$ na forma aniônica e $4 \%$ na forma catiônica. Já o ciprofloxacino, que difere do enrofloxacino apenas pela presença de um átomo de hidrogênio no anel piperazínico, encontra-se $90 \%$ na forma de íon dipolar e $10 \%$ na forma aniônica.

De acordo com as constantes de acidez e diferentes estruturas, as quinolonas vão exibir diferentes ações antibacterianas. Sendo as porinas uma das principais vias de entrada das quinolonas nas células bacterianas Gram-negativas, a hidrofobicidade, o peso molecular, e a forma iônica em $\mathrm{pH}$ fisiológico são propriedades que vão influenciar a interação destes fármacos. No caso das bactérias Gram-positivas, que não possuem uma membrana externa onde estariam os canais porínicos, a difusão do antibiótico ocorre através da membrana celular e, neste caso, a hidrofobicidade do composto é a propriedade mais importante ${ }^{20}$.

No âmbito clínico, o enrofloxacino destina-se apenas para uso veterinário, enquanto o ciprofloxacino é indicado para infecções urinárias, o levofloxacino para pneumonias e o moxifloxacino é indicado para pneumonias e infecções abdominais, como apendicite e diverticulite. Em 2010, o levofloxacino foi o antibiótico mais vendido nos Estados Unidos ${ }^{22}$.

No ano de 2013, após mais de dois mil processos movidos por pacientes que sofreram reações adversas severas após a administração oral ou injetável de fluoroquinolonas, o órgão regulamentador dos Estados Unidos nessa área, Food and Drug Administration (FDA), emitiu um comunicado exigindo que os laboratórios farmacêuticos advertissem em suas bulas que as 
fluoroquinolonas podem causar danos permanentes no sistema nervoso central ${ }^{23}$. Além disso, pesquisadores já haviam levantado a possibilidade de que pacientes tratados com esses antibióticos estavam mais suscetíveis a descolamento de retina, glaucoma e rompimento dos tendões ${ }^{24,25}$.

Pesquisadores creditam essa neurotoxicidade das fluoroquinolonas ao átomo de flúor presente em sua estrutura. O flúor, principalmente na forma de fluoreto, é conhecidamente uma neurotoxina, que penetra nos tecidos facilmente devido ao seu pequeno tamanho e alta carga negativa ${ }^{26}$. Essas características permitem às fluoroquinolonas (e outros fármacos que possuem flúor em sua estrutura) atravessar com certa facilidade a barreira hematoencefálica, chegando aos neurônios e podendo causar danos muitas vezes irreversíveis.

Devido a esses fatores, torna-se interessante estudar formas de degradação que gerem produtos menos tóxicos. Além disso, a correta identificação dos produtos dessas degradações também é pertinente, para avaliar o risco que esses produtos trazem. Nesse trabalho, foi avaliada a degradação e pré-concentraçao do ciprofloxacino, cujas principais características encontram-se no Quadro 1.

Quadro 1 - Principais características químicas do ciprofloxacino

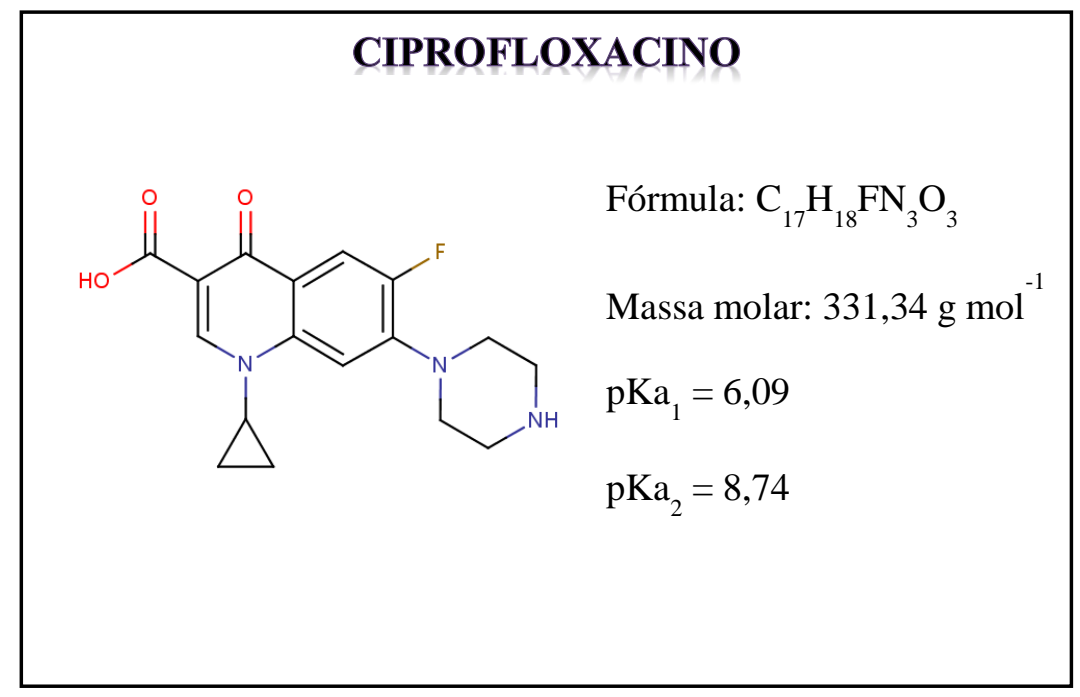

Fonte: TORNIAINEN, K. Int. J. Pharm., v.132, p.53-61, 1996 ${ }^{27}$.

\subsection{Sulfonamidas}

As sulfonamidas ( $\mathrm{SFs}$ ) foram os primeiros antimicrobianos a serem utilizados na prática clínica, através da sulfacrisoidina, em $1935^{28}$. O desenvolvimento de espécies 
resistentes e o fato de apresentarem uma toxicidade significativa têm limitado a sua utilidade terapêutica.

As sulfonamidas constituem um grupo de antibióticos com ação bacteriostática. Elas interferem na utilização do ácido p-aminobenzóico (PABA) na biossíntese de ácido tetrahidrofólico (THF, forma reduzida do ácido fólico), um importante metabólito na síntese de DNA, em bactérias suscetíveis. As sulfonamidas são análogos estruturais do PABA e interferem na utilização do PABA através da inibição competitiva da enzima dihidropteroato sintase, que catalisa a formação de ácido dihidropteróico (um precursor do ácido tetrahidrofólico) a partir do PABA. Portanto, somente microrganismos que sintetizam o seu próprio ácido fólico são inibidos pelas sulfonamidas. Existem também outros passos dessa via biossintética em que se pode intervir de forma a inibir o crescimento bacteriano. Compostos como a pirimetamina e o trimetoprim, que bloqueiam fases posteriores da síntese do ácido fólico, são capazes de agir sinergicamente com as sulfonamidas ${ }^{29}$.

As células animais não são afetadas por essa classe de antibióticos, uma vez que elas utilizam ácido fólico pré-formado e não são capazes de sintetizá-lo. Por outro lado, as bactérias que forem capazes de utilizar precursores do ácido fólico ou ácido fólico préformado também não vão ser afetadas pelas sulfonamidas, sendo, por isso, resistentes a esse grupo de fármacos ${ }^{29}$.

Apesar de se limitarem aos microrganismos que sintetizam seu ácido fólico, as sulfonamidas possuem um espectro de ação relativamente amplo, atingindo bactérias Grampositivas, Gram-negativas e muitos protozoários, sendo indicadas para infecções intestinais e respiratórias, artrites, pododermatites, mastites e metrites, meningoencefalites e infecções urinárias $^{29,30}$.

As sulfonamidas apresentam uma metabolização altamente dependente da espécie. Enquanto suínos não formam metabólitos $\mathrm{N}^{1}$-glicuronídeos da sulfadimetoxina, os humanos já os formam. No caso da sulfadiazina, tanto suínos quanto humanos produzem seu metabólito acetilado ${ }^{28}$. A Figura 1 mostra as principais transformações metabólicas que são sofridas por uma molécula genérica de sulfonamida.

A ecotoxicidade das sulfonamidas é classificada em termos de sua influência nos insetos e nos organismos presentes no solo e na água, bem como sua transformação no ambiente. A presença de resíduos de sulfonamidas no ambiente, acumulados por biodegradação ou degradação não biológica, facilita a evolução de cepas resistentes, afetando o crescimento da flora e da fauna. Após longa exposição às sulfonamidas, inclusive humanos podem sofrer de desordens no trato urinário e hematopoiéticas. Algumas sulfonamidas 
também possuem potencial carcinogênico, o que as torna um potencial problema para a saúde humana ${ }^{31}$.

Figura 1 - Possibilidades de metabolização comumente reportadas para sulfonamidas. Em cinza, reações de oxi-redução e em branco, reações de conjugação.

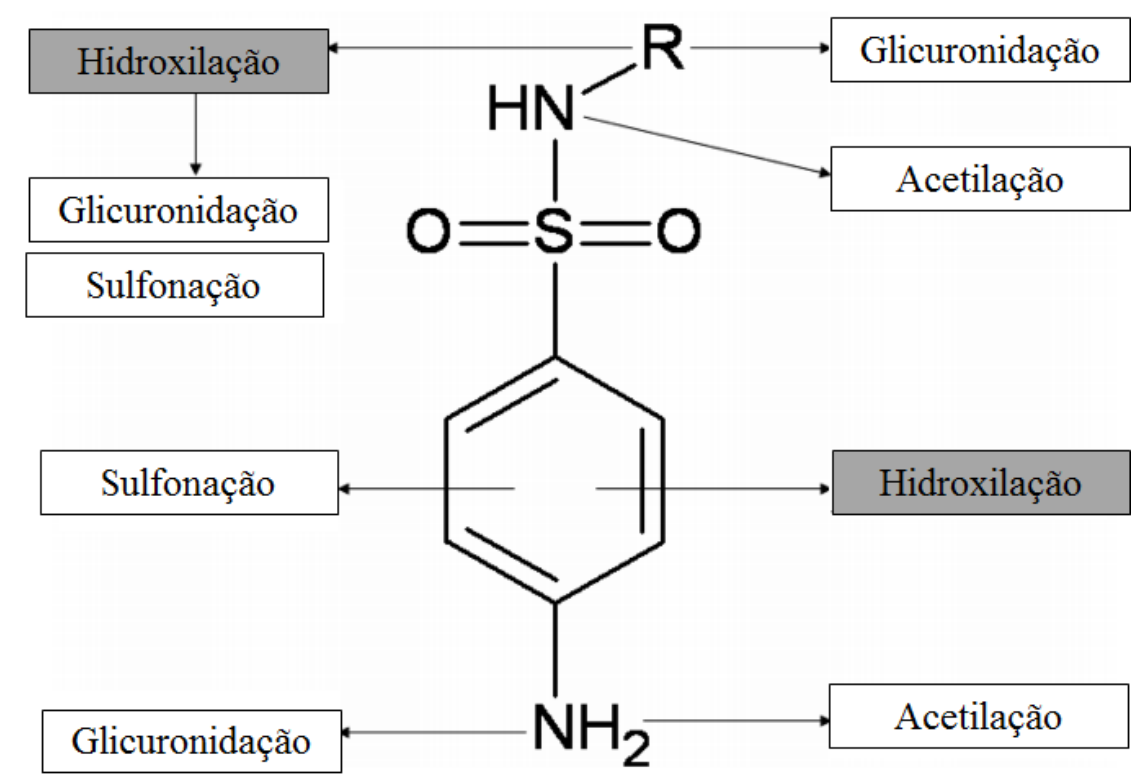

Fonte: Adaptado de HOFF, R. B. Anal. Chem., v. 86, p.5580, $2014^{28}$.

A sulfametazina (Quadro 2), fármaco estudado por este trabalho, foi a primeira sulfonamida a ser largamente utilizada em suínos. Sua aplicação é limitada exclusivamente ao uso veterinário. Porém, devido às suas características farmacocinéticas e seu longo tempo de permanência no organismo, a sulfametazina tem sido relacionada aos resíduos de antibióticos encontrados nos tecidos suínos ${ }^{32}$. Muitas vezes, esses resíduos excedem o limite preconizado por agências regulatórias e, considerando a fiscalização precária ou a venda de carne ilegal, a população pode consumir produtos fora de especificação, correndo risco de sofrer sérios danos à saúde a curto ou longo prazo.

Em um artigo sobre ocorrência de fármacos em lençóis freáticos e águas de superfície $^{33}$ é relatado que estudos de modelagem mostram que as sulfonamidas percolam muito facilmente pelos solos, chegando rapidamente tanto em águas de superfície e quanto em lençóis freáticos. A presença de sulfametazina nos lençóis foi quantificada nesse mesmo artigo e sua concentração variou de 120 a $616 \mathrm{ng} \mathrm{L}^{-1}$. 
Quadro 2 - Principais características químicas da sulfametazina

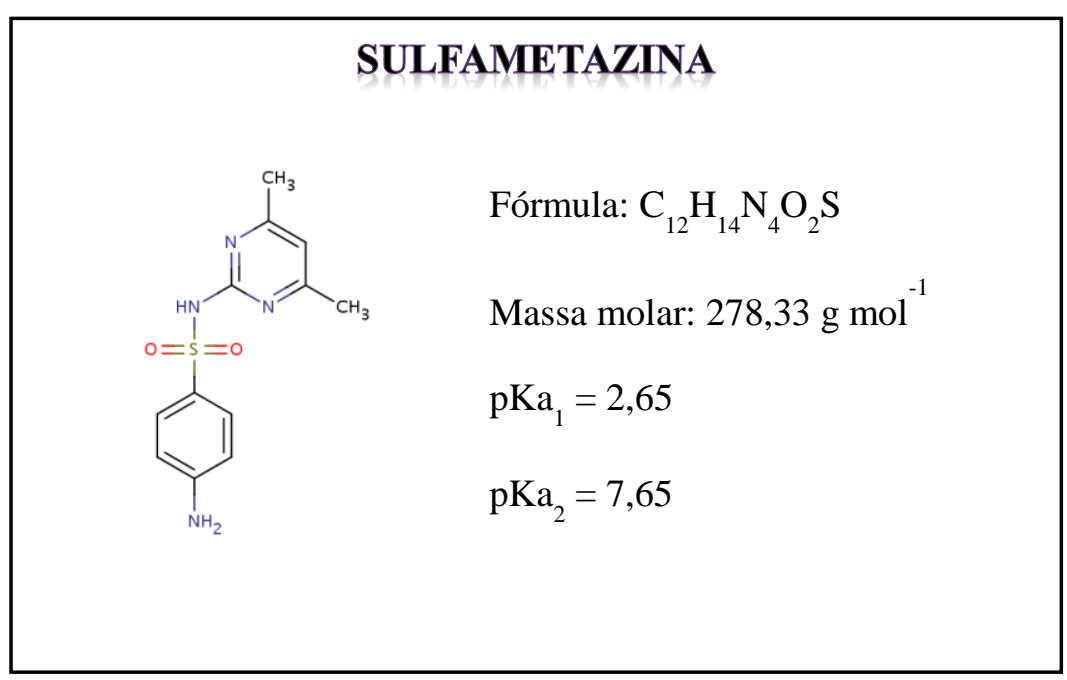

Fonte: TOLLS, J. Environ. Sci. Technol., v. 35, p.3397-3406, $2001^{34}$.

\subsection{Produtos de degradação}

Alguns artigos e revisões da literatura têm mostrado a ineficácia dos tratamentos convencionais em remover os antibióticos e outros fármacos das águas residuárias ${ }^{35-37}$. LeMinh e colaboradores, além de relatarem a ineficiência dos métodos convencionais de tratamento, fazem extensivas considerações acerca dos estudos atuais e necessidades futuras $^{36}$. Em síntese, nesse trabalho eles relatam a falta de controle sobre as variáveis envolvidas em alguns estudos de degradação, as quais estão diretamente relacionadas, por exemplo, com atividades enzimáticas reguladoras do processo; mencionam a possibilidade da formação de produtos de degradação ou metabólitos com atividade, mesmo nos casos de altas eficiências de remoção da substância na forma inalterada; e declararam a escassez de informações relativas aos processos mais elaborados de tratamento de resíduos ${ }^{36}$.

Atualmente, o único metabólito que recebe considerável atenção da literatura científica é o metabólito acetilado do sulfametoxazol ${ }^{38}$. $\mathrm{O} \mathrm{N}_{4}$-acetilsulfametoxazol está presente na excreção humana em $50 \%$ da dose administrada de fármaco inalterado. Esse metabólito também pode se desconjugar novamente em sulfametoxazol durante o tratamento de efluentes, levando a erros na estimativa de eficiência de remoção do fármaco. Com exceção do $\mathrm{N}_{4}$-acetilsulfametoxazol, todos os outros metabólitos e produtos de degradação são negligenciados em grande parte dos trabalhos que abordam a remoção de antibióticos e outros fármacos em tratamento de efluentes. 
Esses produtos de degradação podem ser tão nocivos quanto os fármacos em si. Apesar da grande preocupação acerca desse assunto, o pequeno número de trabalhos da literatura científica que aborda o tema pode ser devido às baixas concentrações nas quais os produtos se apresentam no meio ambiente e na dificuldade de isolá-los da matriz em que estão presentes. A dificuldade reside no fato desses compostos serem, em sua maior parte, desconhecidos, e muitas vezes com algumas características estruturais bastante diferentes daquelas dos fármacos que lhes deram origem. Ou seja, os métodos usados com êxito para isolar os fármacos inalterados da matriz podem não ser eficientes para seus produtos de degradação ${ }^{39}$.

\subsection{Técnicas de preparo de amostra}

A pesquisa envolvendo resíduos de fármacos e seus respectivos produtos de degradação enfrenta o desafio de analisar compostos em concentrações muito baixas, na ordem de $\mu \mathrm{g} \mathrm{L}^{-1}$ e ng L ${ }^{-1}$. Esses analitos geralmente estão em efluentes, lençóis freáticos e águas de superfície, que possuem uma composição mais complexa, se comparada com a água purificada utilizada em laboratórios e no abastecimento da população. Dessa forma, é necessário utilizar técnicas de preparo de amostra para concentrar os compostos de interesse (fármacos e seus produtos de degradação) e eliminar possíveis compostos inerentes à matriz que venham a interferir na análise.

Com o passar dos anos, foram desenvolvidas as mais diversificadas técnicas para extrair analitos dos mais variados tipos de matriz. A escolha da técnica depende do tipo de matriz (sólida, líquida ou gasosa) e do tipo de analito (volátil ou não-volátil).

Para que a escolha seja feita da maneira correta, deve-se também considerar o tipo de análise que será feita. A cromatografia líquida (LC) requer um preparo de amostra que permita baixos limites de detecção (LOD) e de quantificação (LOQ), linearidade, precisão e exatidão. Quando a LC está acoplada à espectrometria de massas (MS), deve-se evitar o efeito de matriz, que suprime ou aumenta o sinal dos analitos, altera os parâmetros recém-descritos e afasta os resultados obtidos da realidade.

Uma das técnicas mais bem estabelecidas para matrizes líquidas e analitos nãovoláteis é a extração em fase sólida (SPE - solid phase extraction). Nessa técnica, a fase extratora é colocada em cartuchos, e é condicionada com solventes para reter os analitos de interesse quando houver a passagem da matriz. Seguem-se as etapas de lavagem, para 
eliminar interferentes retidos na fase, e de eluição, para retirar os analitos de interesse da fase extratora e levá-los para a análise com a técnica escolhida ${ }^{40}$.

A SPE é uma técnica de extração consagrada e com métodos bem desenvolvidos, geralmente obtém êxito em extrair analitos como fármacos de matrizes aquosas. Sua vantagem é que permite que sejam passados pelo cartucho grandes volumes de matriz, concentrando quantidades consideráveis de analitos de interesse. Cartuchos com fases extratoras diferentes também podem ser facilmente acoplados. Sua desvantagem é o tempo gasto na extração, o grande volume de solvente utilizado e a não reutilização dos cartuchos utilizados para extração, o que pode torná-la uma técnica dispendiosa ${ }^{40}$.

Para contornar as desvantagens da SPE, foram desenvolvidas nas últimas décadas microtécnicas de preparo de amostra, que utilizam os princípios da SPE, mas com quantidades reduzidas de fase extratora, amostra e solventes. Dentre elas, destacam-se a microextração em fase sólida (SPME - solid phase microextraction) e a microextração por sorvente empacotado (MEPS - microextraction by packed sorbent).

A SPME é uma técnica desenvolvida por Janus Pawliszyn e baseia-se em uma pequena quantidade de fase extratora imobilizada em um suporte sólido (geralmente uma fibra ou haste de sílica). Esse aparato é exposto à amostra por um período de tempo bem definido. Um equilíbrio de partição é estabelecido entre a matriz da amostra e a fase extratora e o analito é extraído. Procede-se, então, a transferência do analito para o sistema de análise. No caso de cromatografia gasosa (GC), a fibra com o analito pode ser inserida diretamente no injetor do cromatógrafo. Já no caso de LC, pequenas quantidades de solvente são utilizadas para eluir o analito da fibra e então é feita a injeção. A SPME é conhecida por utilizar muito pouco ou, em alguns casos, nenhum solvente. Para analitos voláteis, há uma variação da técnica, chamada de headspace, na qual a fibra de SPME não entra em contato com a matriz, ficando suspensa sobre ela ${ }^{41}$. Geralmente, o equilíbrio de partição extrai pequenas quantidades de analito presente na amostra, por isso, a SPME pode não ser a técnica mais indicada para amostras nas quais o analito está em concentrações muito baixas.

Já MEPS utiliza mais diretamente os conceitos de SPE e foi escolhida como técnica de extração neste trabalho. Seus fundamentos estão expostos na seção 1.4.1.

\subsubsection{Microextração por sorvente empacotado (MEPS)}

MEPS, uma das mais recentes técnicas de preparo de amostra, baseia-se na miniaturização da SPE convencional. Os volumes utilizados em MEPS, tanto de solventes 
quanto de amostra, foram consideravelmente reduzidos, se comparados à SPE. Em MEPS, o volume total de solventes e amostra não ultrapassa $5 \mathrm{~mL}$ a cada extração executada ${ }^{42}$. Devido a isso, MEPS é uma técnica que aplica com êxito um dos principais conceitos de Química Verde, que é a redução da quantidade de reagentes.

MEPS, quando comparada à SPME, apresenta vantagens, pois o equilíbrio de partição do analito entre fase extratora e a matriz é praticamente todo deslocado para a fase extratora, já que são executados diversos ciclos aspirar/dispensar. Na SPME, o tempo para atingir o equilíbrio é maior que em MEPS e a fina camada de filme de fase extratora muitas vezes não pré-concentra o analito em quantidade suficiente para este ser detectado. Dessa forma, MEPS é mais indicado que SPME para amostras muito diluídas, pois apresenta altas taxas de préconcentração A Tabela 2 apresenta alguns parâmetros comparados entre as técnicas MEPS, SPME e SPE ${ }^{43-45}$.

Tabela 2 - Comparações de parâmetros entre as técnicas MEPS, SPE e SPME

\begin{tabular}{lccc}
\hline Parâmetro & MEPS & SPE & SPME \\
\hline Quantidade de sorvente & $0,5-2 \mathrm{mg}$ & $50-2000 \mathrm{mg}$ & Espessura: $150 \mathrm{~mm}$ \\
Tempo de preparo de amostra & $1-2 \mathrm{~min}$ & $10-15 \mathrm{~min}$ & $10-40 \mathrm{~min}$ \\
Reutilização do sorvente & $40-100$ extrações & Uma vez & $50-70$ extrações \\
Recuperação & Boa & Boa & Baixa \\
Detectabilidade & Boa & Boa & Baixa \\
\hline
\end{tabular}

Fonte: ABDEL-REHIM, M. Journal of Chromatography B, v. 801, p. 317-321, $2004^{45}$.

Em MEPS, um dispositivo que contém a fase extratora, chamado de BIN (barrel insert and needle), com dimensões aproximadas de $0,7 \mathrm{~cm}$ de comprimento e $0,2 \mathrm{~mm}$ de diâmetro interno, é empacotado com aproximadamente $1 \mathrm{ou} 2 \mathrm{mg}$ de fase extratora e acoplado à agulha de uma microsseringa, com volumes que variam entre100 e1000 $\mu$ L. A Figura 2 apresenta um esquema ilustrativo da microsseringa e do dispositivo de extração utilizados em MEPS.

Na microsseringa comercial, o dispositivo de extração é feito de aço inoxidável e soldado à agulha. Diversas fases extratoras estão disponíveis comercialmente, como sílica, para fase normal; C2, C8 e C18, para fase reversa; polímeros catiônicos e aniônicos, para troca iônica. Uma grande desvantagem da utilização do dispositivo de extração comercial é que em caso de entupimentos (que ocorre principalmente com fluidos biológicos e matrizes muito complexas), todo o dispositivo deve ser trocado, o que pode tornar a técnica dispendiosa. 
Devido a isso, nosso grupo de pesquisa desenvolveu um dispositivo de extração análogo ao BIN, mas que pode ser desmontado no caso de entupimentos ou em que se queira mudar a fase extratora. Dessa forma, a técnica se torna menos dispendiosa e mais versátil.

Descrevendo MEPS de maneira simplificada, o dispositivo de extração é acoplado à microsseringa e todas as etapas da extração ocorrem através de ciclos aspirar/dispensar que são otimizados de acordo com os analitos a serem pré-concentrados e sua afinidade com a fase extratora utilizada.

Figura 2 - Microsseringa MEPS $(250 \mu \mathrm{L})$ e dispositivo de extração com material sorvente empacotado.
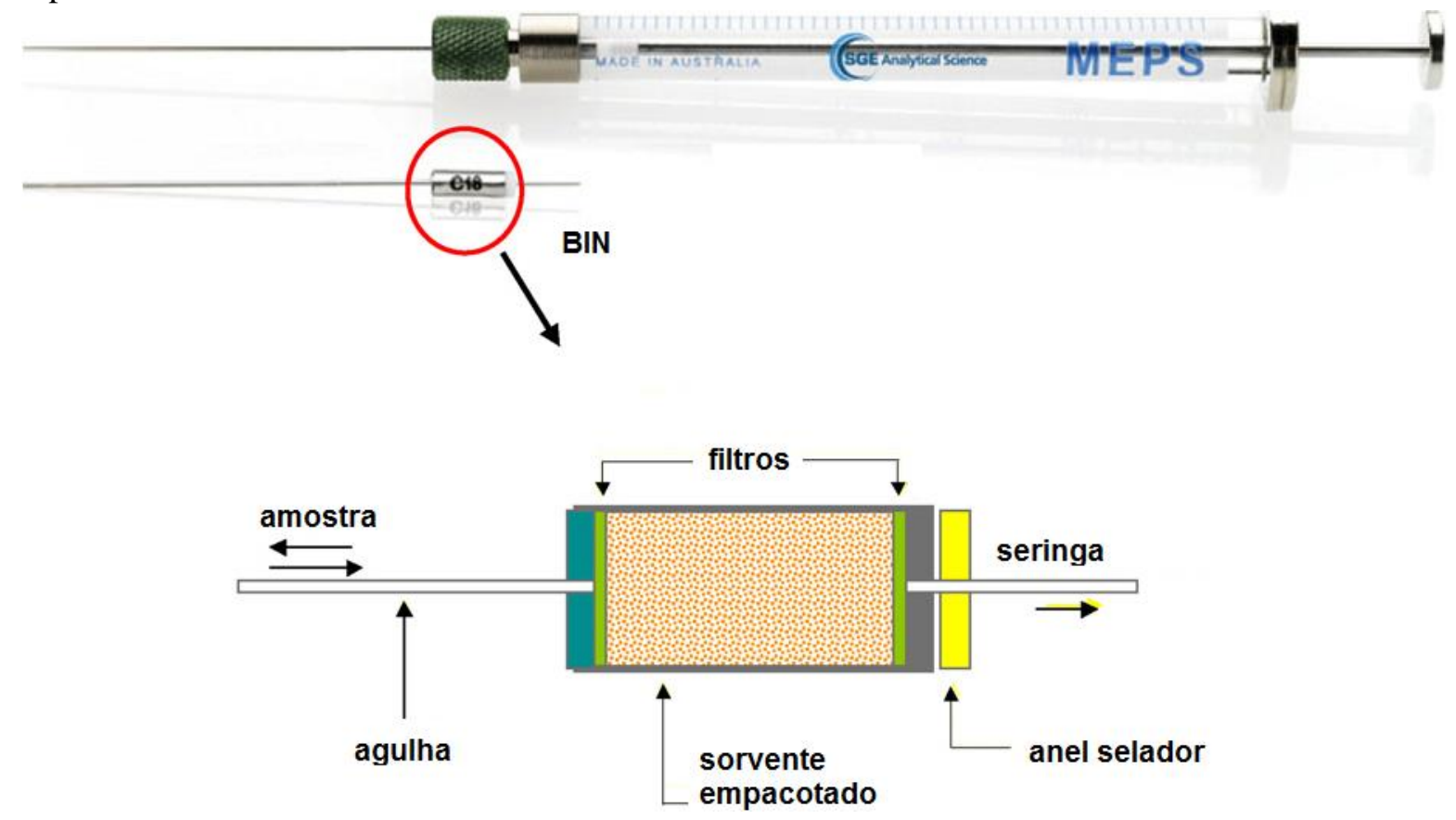

Fonte: Adaptado de ABDEL-REHIM, M., Journal of Chromatography A, v.22, $2010^{42}$.

Primeiramente, a fase extratora é condicionada com solvente orgânico. A polaridade do solvente depende da fase extratora. Geralmente, utiliza-se metanol e água purificada em $\mathrm{pH}$ ácido. Tal etapa tem a finalidade de ativar os grupamentos presentes no sorvente que efetivamente fazem as interações com o analito. Após o condicionamento, a próxima etapa é a amostragem. Nessa etapa, a matriz que contém o analito passa pela fase extratora através dos ciclos aspirar/dispensar e o analito fica retido por forças intermoleculares aos grupamentos presentes no sorvente. Essa etapa é crucial para o êxito da extração e deve ser feita cuidadosamente. Quando se trata de matrizes complexas, logo após a amostragem há uma etapa de lavagem, na qual um solvente (geralmente água ou combinações de água com algum 
solvente orgânico polar) passa pela fase extratora no intuito de retirar eventuais compostos endógenos da matriz que porventura ficaram retidos junto com os compostos de interesse. A etapa de lavagem requer cuidado na escolha do solvente e no número de ciclos aspirar/dispensar, para que os compostos de interesse não sejam eluidos junto com os interferentes. Feita a lavagem, passa-se para a etapa de eluição. O solvente de eluição deve ser escolhido de forma que solubilize os analitos que ficaram retidos na fase extratora. Para tanto, modificações no $\mathrm{pH}$ do solvente podem ser feitas, para que a maior quantidade possível de analito seja recuperada, atingindo altas taxas de pré-concentração. Para maior eficiência na extração, a eluição pode ser feita por etapas (utilizando dois ou mais volumes do eluente), e o ideal é que o volume final de solvente utilizado na eluição corresponda à taxa de préconcentração desejada, pois uma etapa posterior de secagem pode acarretar perdas do analito. A Figura 3 ilustra as etapas de pré-concentração por MEPS ${ }^{45}$.

Visando a reutilização da fase extratora, é feita uma nova lavagem entre as extrações. Geralmente é utilizado o mesmo solvente de condicionamento ou de eluição, porém em maior quantidade, para que moléculas de analito que não foram eluídas ou interferentes que ficaram retidos sejam solubilizados. Dessa forma, o dispositivo está limpo para uma nova extração. A etapa de lavagem minimiza efeitos de memória (carryover) a valores menores que $0,02 \%$ e torna a técnica de MEPS ambientalmente correta e menos dispendiosa.

A fase extratora contida no dispositivo de extração tem sido reutilizada aproximadamente 120 vezes, em matrizes aquosas menos complexas, sem perder sua eficiência significativamente. Quanto mais limpa a matriz da amostra, mais vezes o dispositivo pode ser reutilizado. Já os cartuchos de SPE, geralmente são utilizados uma única vez e descartados.

Em relação às amostras de plasma ou soro, o tratamento prévio da amostra é importante para aumentar o tempo de vida da fase extratora de MEPS. Há relatos de que esta tem sido reutilizada mais de 100 vezes para as amostras de plasma centrifugadas e de 40 a 50 vezes para amostras de plasma não-centrifugadas ${ }^{42}$.

A seleção da fase extratora é um fator imprescindível para a obtenção de êxito na extração e altas taxas de recuperação. Fases como C2, C8 e C18 são adequadas para extração de compostos lipofílicos, enquanto as fases poliméricas, tais como poliestirenodivilnilbenzeno com grupos iônicos quimicamente ligados (troca iônica) ou fases mistas (C8 + SCX) são mai apropriadas para as determinações de compostos polares como aqueles com propriedades ácidas e básicas. Os materiais de acesso restrito (RAM) ou polímeros 
molecularmente impressos (MIP) também têm sido utilizados como fases extratoras para MEPS $^{56}$ em dispositivos não-comerciais.

Figura 3 - Ilustração das etapas do processo MEPS.

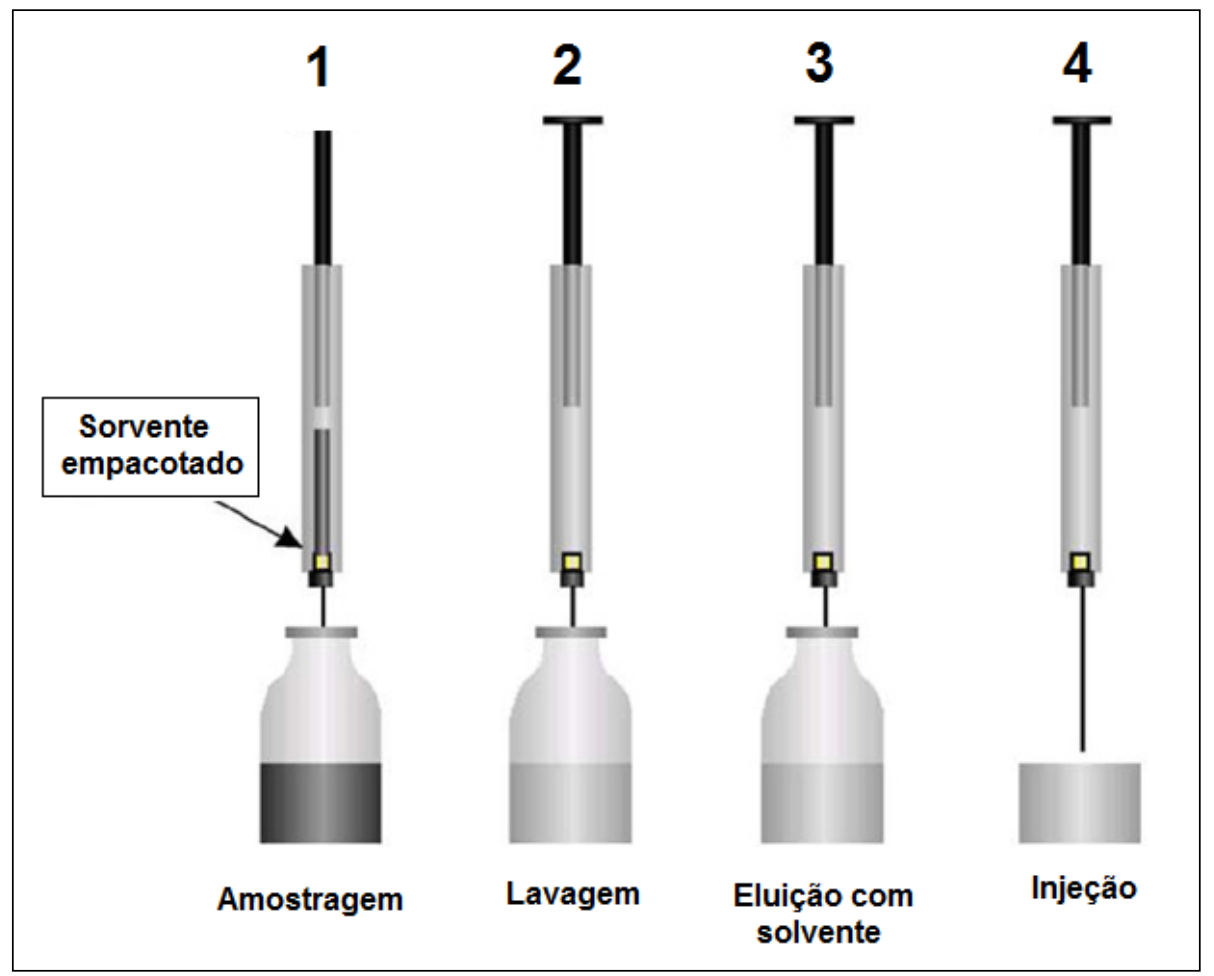

Fonte: Adaptado de ABDEL-REHIM, M. Journal of Chromatography B, v. 801, 2004 ${ }^{45}$.

\subsection{Cromatografia líquida de alta eficiência acoplada à espectrometria de massas (LC-MS)}

O acoplamento da cromatografia líquida com a espectrometria de massas pode ser considerado um dos mais importantes avanços em técnicas analíticas das últimas décadas. A técnica de LC-MS tem sido a escolha analítica das mais diversas indústrias e centros de pesquisa tanto para as amostras biológicas quanto para as ambientais ${ }^{46}$.

A resolução apresentada pela MS é muito útil quando acoplada à separação cromatográfica pela LC. Como é sabido, somente a separação cromatográfica não fornece dados suficientes para confirmar se uma banda cromatográfica realmente corresponde ao composto de interesse. Dessa forma, a MS aumenta a seletividade da cromatografia líquida ${ }^{46}$.

Uma das principais limitações do acoplamento da LC com a MS é que enquanto a LC trabalha com fases móveis líquidas, as fontes de ionização originais para MS obtinham maior 
sucesso na ionização de analitos na fase gasosa. Logo, fez-se necessária uma interface que facilitasse a ionização dos compostos quando esses saem do cromatógrafo a líquido e entram no espectrômetro. A solução de maior sucesso nesse caso são as interfaces de ionização à pressão atmosférica (API), pois a fase líquida quando vaporizada é mais facilmente eliminada nesse tipo de $\operatorname{arranjo}^{46}$. A API tem como vantagens fornecer informações sobre a massa molecular dos compostos, desde pequenas moléculas até grandes polímeros; a depender do analisado, a massa molecular pode ser obtida com exatidão mesmo com pequenas concentrações de analito; e a técnica é compatível com analitos voláteis, não-voláteis, polares e apolares ${ }^{46}$. Os tipos mais utilizadas de API são a ionização química à pressão atmosférica (APCI - Atmospheric-pressure chemical ionization) e a ionização por electrospray (ESI Electrospray ionization).

Na APCI, a fase móvel com analito que chega à fonte é vaporizada com o auxílio de nebulização por $\mathrm{N}_{2}$ e logo após seca, passando através de uma região aquecida entre 350 e $550^{\circ} \mathrm{C}$. Após o processo de vaporização, é aplicada uma descarga corona através de uma agulha, que ioniza preferencialmente as moléculas provenientes do solvente da fase móvel, que estão em maior quantidade. A partir de então, passam a ocorrer reações entre os íons gerados pela descarga e as moléculas neutras do analito, gerando íons do analito que serão enviados ao analisador. A APCI é compatível com vazões mais altas de fase móvel proveniente do sistema de LC (até 2,0 $\mathrm{mL} \mathrm{min}^{-1}$ ). Sua ionização é muito eficiente e fornece informações de massa molecular. Porém, o analito deve ser termicamente estável, ser apolar ou de média polaridade e preferencialmente não possuir relações massa/carga (m/z) acima de $2000^{47}$.

A ESI é uma técnica aplicável às moléculas de alta e média polaridade. A ESI utiliza a energia elétrica para auxiliar a transferência dos íons da solução para a fase gasosa, antes que eles sejam submetidos à análise por MS. Essa transferência ocorre pelos seguintes passos: (1) dispersão em fino spray de gotículas carregadas; (2) evaporação do solvente e (3) projeção dos íons mais carregados. Dentro da fonte ESI, uma vazão contínua de fase móvel passa através de um capilar de sílica ou de aço inoxidável, que é mantido sob alta voltagem. Um spray de gotículas altamente carregadas com a mesma polaridade da tensão aplicada no capilar é gerado. A aplicação de um gás nebulizador (como o nitrogênio) aumenta a capacidade formação do spray permitindo maior vazão de fase móvel, diminuindo o tamanho das gotículas geradas. As gotículas carregadas passam por um gradiente de pressão e de potencial, em direção ao analisador do espectrômetro de massas. Com o auxílio de temperatura ou de uma corrente de gás nitrogênio, essas gotículas carregadas são reduzidas de 
tamanho continuamente por evaporação do solvente, levando a um aumento de densidade de cargas na sua superfície e a uma diminuição no raio da gota. Finalmente, o forte campo elétrico interno da gota atinge um ponto crítico, no qual é cinética e energeticamente possível que os íons da superfície da gota sejam ejetados para a fase gasosa. Os íons emitidos são coletados através de um cone, orifício ou capilar, sendo acelerados em direção ao analisador de massas, onde serão analisadas sua razão massa/carga e obtida a intensidade deste sinal $^{48}$.

A ESI permite a ionização de compostos de alta relação $\mathrm{m} / \mathrm{z}$, mas a vazão da fase móvel proveniente do sistema de LC não pode ser usualmente maior que $1,0 \mathrm{~mL} \mathrm{~min}{ }^{-1}$, sendo que, quanto menor a vazão, melhores os resultados da ionização. Outra característica da ESI é que as cargas que formarão os íons que serão enviados para o analisador já devem estar em solução quando a fase móvel com o analito chega do sistema cromatográfico. Se o próprio analito é ionizável, a tendência é que ele se dissocie na fonte de ESI. Porém, nem sempre os analitos são ionizáveis (principalmente se tratando da cromatografia líquida em fase reversa) e geralmente utiliza-se modificadores orgânicos, como ácido fórmico ou acetato de amônio, que favorecem o processo de ionização dos analitos ${ }^{47}$.

Pode-se dizer que APCI e ESI são técnicas complementares, pois apresentam diferenças importantes em relação à polaridade, vazão de fase móvel e faixa de $\mathrm{m} / \mathrm{z}$ dos analitos a serem analisados. Tanto por APCI quanto por ESI ocorre ionização branda, pois a energia empregada nessas fontes não é suficiente para gerar fragmentações mais severas ${ }^{47}$. Devido ao aquecimento, APCI pode gerar alguma fragmentação, enquanto ESI tende a gerar somente íons pseudo-moleculares.

Este trabalho foi desenvolvido utilizando fármacos moderadamente polares como analitos e por estes virem acompanhados de seus produtos de degradação (até então desconhecidos), mas geralmente mais polares, a ESI foi escolhida como fonte de ionização.

Após a ionização dos analitos, os íons recém-formados são enviados para os analisadores de massa, que fazem a separação dos íons por sua carga e massa, dando origem ao espectro de massa. Considerando a LC acoplada à MS, três tipos de analisadores são os mais utilizados: quadrupolo (Q), aprisionador de íons (IT - ion trap) e tempo de voo (ToF time of flight).

O quadrupolo possui dois pares de barras paralelos. Os pares opostos são conectados eletricamente e recebem potenciais elétricos de cargas opostas. A aplicação das tensões altera a trajetória linear dos íons. Variando-se as tensões, somente íons com determinada razão $\mathrm{m} / \mathrm{z}$ irão atravessar pelo centro do quadrupolo, enquanto os outros íons serão desviados desta 
trajetória central, sendo eliminados ${ }^{40}$. O quadrupolo é um analisador clássico, tem boa reprodutibilidade e é muito eficiente em análises cujo objetivo é a quantificação de analitos conhecidos, pois possibilita ótima relação sinal/ruído. Porém, possui resolução limitada e baixa exatidão de massas.

O ion trap possui três eletrodos que aprisionam os íons em seu interior. As tensões geram uma trajetória estável para os íons, até que uma determinada tensão aplicada torne os íons de determinada razão $\mathrm{m} / \mathrm{z}$ instáveis e eles então são ejetados do trap formado pelos eletrodos. Essa liberação controlada dos íons permite uma separação entre diferentes razões massa/carga que confere ao IT um poder de resolução de massas equiparável ao de um quadrupolo convencional ${ }^{40}$.

No ToF, o princípio é de que os íons formados adquiram a mesma energia cinética em um processo de aceleração, permitindo que suas velocidades diferenciadas relacionem-se com a massa/carga desses íons. Dessa forma, todos os íons que entram no analisador recebem a mesma intensidade de energia para atravessar o "tubo de voo", mas aceleram de formas diferentes devido à sua relação massa/carga $(\mathrm{m} / \mathrm{z})$ e chegam ao detector em tempos diferentes. Os íons de menor m/z têm maior velocidade e chegam ao detector primeiro, bem como os de maior $\mathrm{m} / \mathrm{z}$ são mais lentos e chegam por último. Medindo o tempo de voo dos íons no tubo, pode-se deduzir sua relação $\mathrm{m} / \mathrm{z}$ (geralmente através de calibrações com massas exatamente conhecidas), podendo-se analisar desde compostos com baixa massa molecular até macromoléculas ${ }^{49}$.

Teoricamente, os analisadores ToF não possuem limite de massa, por isso são excelentes para o acoplamento com a técnica de LC. Esse analisador também possui alta taxa de transmissão de íons, tendo, assim, alta sensibilidade. O aumento da distância do tubo de voo ajuda a melhorar a resolução e o aumento da tensão de aceleração aumenta a sensibilidade. Dessa forma, os equipamentos geralmente têm até 2 metros de tubo de voo e até 20 kV de tensão de aceleração.

Atualmente, para maior seletividade e melhor detectabilidade, são utilizadas técnicas sequenciais de espectrometria de massas. Nessas técnicas, íons selecionados são fragmentados e enviados para outro analisador. Essa fragmentação induzida é útil principalmente para melhorar a análise de concentrações muito baixas de analitos, de amostras com matrizes muito complexas, ou de ambas ${ }^{40}$. Para a execução da MS sequencial, são utilizadas combinações de analisadores, como o triplo quadrupolo (QqQ) e o quadrupolo-tempo de voo (Q-ToF), arranjados sequencialmente no espaço. Adicionalmente, podem ser usados 
aprisionadores de íons (IT) com a capacidade de realizar análises sequenciais no tempo, com resultados similares.

\subsubsection{Efeitos de matriz em espectrometria de massas}

$\mathrm{O}$ efeito de matriz ocorre em espectrometria de massas quando um ou mais interferentes presentes no extrato da amostra coeluem com os compostos de interesse da análise. Devido à alta seletividade e especificidade, a análise por MS fica suscetível a erros na presença de compostos endógenos da matriz, principalmente na ionização dos compostos de interesse. O mecanismo de surgimento do efeito de matriz ainda não é totalmente compreendido, mas pode ser relacionado à competição entre os interferentes da matriz e os analitos de interesse da amostra ${ }^{50}$.

Em alguns estudos ${ }^{51}$, mostrou-se que os efeitos de matriz são geralmente provocados por componentes não voláteis presentes na matriz, pela transferência de elétrons do capilar para a solução, e a separação de cargas na superfície das gotas que irão originar os íons em fase gasosa. $\mathrm{O}$ efeito de matriz em MS tende a diminuir ou aumentar a eficiência de formação dos íons dos compostos de interesse e deve ser conhecido para deixar os resultados mais próximos possíveis do real (exatidão). A eficiência de formação dos íons do analito é fortemente dependente da natureza da matriz na fonte de ionização e da natureza química do composto a ser analisado ${ }^{52}$. Um estudo mostrou que o efeito de matriz majoritário na análise de fármacos em esgoto foi causado devido à presença de compostos de baixo peso molecular $(<1 \mathrm{kDa})^{53}$.

O modo mais direto de avaliar o efeito de matriz é comparando uma solução padrão do analito e um extrato da amostra fortificada com o padrão após esta ter passado pelo processo de extração. Diferenças na resposta podem indicar aumento ou diminuição na ionização. Matuszewski, em um estudo clássico ${ }^{54}$, aborda o efeito de matriz de uma maneira quantitativa, utilizando as áreas das bandas cromatográficas para calcular a porcentagem do efeito de matriz (ME) através da Equação 1:

$$
\% M E=\frac{\text { área fortificação pós }- \text { extração }}{\text { área do padrão }} \times 100
$$


A porcentagem de recuperação (RE) da pré-concentração através da Equação 2:

$$
\% R E=\frac{\text { área fortificação pré }- \text { extração }}{\text { área fortificação pós }- \text { extração }} \times 100
$$

E a eficiência total do processo (PE), pela Equação 3:

$$
\% P E=\frac{\text { área fortificação pré }- \text { extração }}{\text { área do padrão }} \times 100=\frac{(\% M E \times \% R E)}{100}
$$

Apesar de não haver limites máximos estabelecidos para o efeito de matriz, é aconselhável que sua magnitude seja estimada e, se possível, minimizada. Além disso, métodos de extração e condições cromatográficas devem ser otimizados e adaptados para minimizar esse efeito ${ }^{55}$. No caso de análises quantitativas, o uso de padrão interno ou o método de adição de padrão é altamente recomendável para uma maior confiabilidade dos resultados.

\subsection{Fotodegradação por radiação ultravioleta (UV)}

Os tratamentos de efluentes mais utilizados atualmente são baseados em tecnologias que somente concentram os poluentes e os transferem para outra fase. Dessa forma, os poluentes ainda permanecem intactos, não sendo completamente eliminados do efluente. Esses poluentes altamente concentrados são, cada vez mais, razão para a preocupação mundial, o que motiva a aprovação de leis cada vez mais rígidas para regular o seu descarte ${ }^{56}$.

Dessa forma, várias alternativas têm sido desenvolvidas para degradar quase que totalmente esses poluentes. Dentre eles estão a fotólise com radiação UV, Fenton e fotoFenton, ozonização e catálise heterogênea com $\mathrm{TiO}_{2}{ }^{57}$.

A fotólise com radiação UV foi escolhida como reação de degradação neste trabalho, devido à sua simplicidade e reprodutibilidade. Esse tipo de reação envolve a interação da luz com as moléculas, que geralmente estão em solução aquosa, para transformá-las em produtos de degradação. Uma degradação completa por fotólise transforma as moléculas de origem em água, $\mathrm{CO}_{2}$ e íons inorgânicos de elementos como cloro, enxofre, fósforo e nitrogênio, provenientes da molécula ${ }^{57}$.

A radiação UV, utilizada nesse tipo de reação, pode ser dividida em três tipos: UV-A, UV-B e UV-C. A radiação UV-A tem seu comprimento de 320 a $400 \mathrm{~nm}$ e chega à superfície terrestre em grande quantidade, emitida pelo sol. A radiação UV-B tem comprimento de 280 a $320 \mathrm{~nm}$ e também chega à superfície terrestre quase que em sua totalidade. Já a radiação UV- 
C tem comprimento de onda menor que $280 \mathrm{~nm}$, o mais distante da luz visível dentre as radiações UV, mas não chega à superfície terrestre, pois é totalmente absorvida pela camada de ozônio $^{58}$. A radiação UV-C emitida por lâmpadas é usada como bactericida e tem a propriedade de interagir com as moléculas, rompendo suas ligações, devido à sua alta energia. Neste trabalho, uma lâmpada de mercúrio de baixa pressão, que emite em $254 \mathrm{~nm}$, é a fonte de UV-C utilizada para fotodegradar os antibióticos.

Porém, não basta apenas degradar os fármacos sem identificar seus produtos de degradação. Esses produtos devem ser identificados e, se possível, avaliados em relação à sua toxicidade, de forma a evitar que sejam liberados no ambiente compostos mais perigosos que seus fármacos de origem ${ }^{59}$.

\subsection{Reatores biológicos anaeróbios}

Digestão anaeróbia é um processo biológico que ocorre naturalmente, no qual compostos orgânicos são quebrados em moléculas mais simples sob condições anaeróbias. Os microrganismos anaeróbios digerem a matéria orgânica para produzir biogás, como metano e dióxido de carbono. O biogás produzido em reatores biológicos usualmente contém pequenas quantidades de sulfeto de hidrogênio e amônia ${ }^{60}$.

A digestão anaeróbia é um processo complexo que compreende três etapas: hidrólise, acidogênese e metanogênese. Durante a hidrólise, bactérias fermentativas convertem complexas moléculas orgânicas insolúveis em moléculas solúveis como ácidos graxos voláteis, aminoácidos e carboidratos ${ }^{61}$. Na segunda etapa, bactérias convertem os produtos da primeira etapa em ácidos orgânicos simples, dióxido de carbono e hidrogênio. A maioria dos compostos produzidos são derivados dos ácidos acético, propiônico e butírico e etanol. Por último, o metano é produzido pelas bactérias responsáveis pela metanogênese ${ }^{61}$.

A digestão anaeróbia envolve os mais variados tipos de microrganismos em uma relação simbiótica, na qual a produção de metano é a etapa mais lenta e mais sensível. Por essa razão, condições de operação específicas devem ser mantidas, como temperatura e $\mathrm{pH}^{62}$. Um dos fatores chave no desenvolvimento de reatores anaeróbios é o ajuste das condições hidrodinâmicas para favorecer a compactação da biomassa, mas ainda assim garantir grande contato entre os substratos do esgoto e a biomassa ${ }^{63}$. A operação de biorreatores anaeróbios depende do desempenho da população microbiana presente no lodo. Dessa forma, torna-se indispensável a caracterização do lodo em termos microbiológicos, cinéticos e físicoquímicos $^{63}$. 


\section{OBJETIVOS}

\subsection{Objetivos Gerais}

Desenvolver e avaliar métodos miniaturizados para a pré-concentração dos principais produtos de degradação de fármacos representantes da classe das fluoroquinolonas (ciprofloxacino) e da classe das sulfonamidas (sulfametazina) em meio aquoso.

\subsection{Objetivos Específicos}

- Gerar produtos de degradação por meio de fotólise em água purificada, detectandoos por cromatografia líquida acoplada à espectrometria de massas;

- Avaliar a capacidade de extração de diferentes sorventes comerciais (Oasis ${ }^{\circledR}$ HLB, nanotubos de carbono), quanto à recuperação dos compostos de interesse utilizando microextração com sorvente empacotado (MEPS) e cromatografia líquida acoplada à espectrometria de massas;

- Desenvolver e aplicar os métodos desenvolvidos por MEPS para pré-concentrar os produtos de degradação em amostras fortificadas com baixas concentrações desses compostos;

- Avaliar o efeito de matriz que interferentes de amostras mais complexas (como esgoto sintético) podem causar nas análises dos produtos de degradação;

- Expor os fármacos de interesse à degradação biológica com o objetivo de avaliar a hipótese de que alguns produtos de degradação obtidos no estresse físico-químico coincidam com os produtos da degradação biológica, bem como verificar se outros eventuais produtos próprios dessa degradação também possam ser isolados. 


\section{PARTE EXPERIMENTAL}

\subsection{Materiais e Reagentes}

Os padrões analíticos da sulfametazina $(\operatorname{SMZ})(\geq 99 \%)$ e do ciprofloxacino (CIP) ( $\geq 98 \%$ ) foram adquiridos da Sigma-Aldrich. A água utilizada foi purificada por uma estação Milli-Q da Millipore. Os solventes orgânicos metanol (MeOH) e acetonitrila (ACN) (grau HPLC) foram adquiridos de Tedia. O modificador orgânico ácido fórmico grau espectroscópico foi adquirido da Sigma-Aldrich.

A fase extratora Oasis ${ }^{\circledR}$ HLB com $60 \mu \mathrm{m}$ de tamanho de partícula, foi adquirida da Waters. Os nanotubos de carbono de múltiplas paredes (MWCNT) foram adquiridos da Sigma-Aldrich (\#694185). Na microextração por sorvente empacotado (MEPS), as microsseringas utilizadas foram adquiridas da Hamilton. $\mathrm{O}$ dispositivo para a extração a ser acoplado na seringa foi desenvolvido por pesquisadores do próprio laboratório ${ }^{64}$.

\subsection{Degradação da sulfametazina por fotólise em meio neutro}

Com o objetivo de avaliar a formação de produtos de degradação gerados durante a fotólise da SMZ, foram feitos experimentos em um reator (Figura 4), com capacidade de $250 \mathrm{~mL}$ acoplado a um sistema de recirculação (a temperatura foi mantida a $25^{\circ} \mathrm{C}$ ) utilizando uma lâmpada UV-C de 9 W.

Figura 4 - Reator Acoplado ao Sistema de Recirculação.

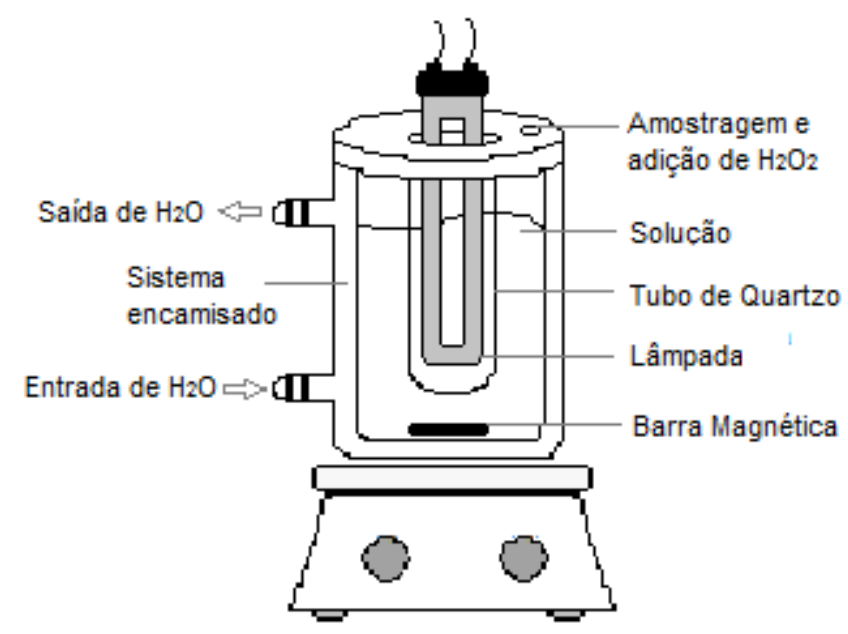

Fonte: FERREIRA, T. C. R., Tese de Doutorado, $2014^{65}$. 
A lâmpada utilizada no presente trabalho foi caracterizada utilizando-se um espectroradiômetro da Luzchem, SPR-01-235-850 nm (Figura 5). Os comprimentos de onda variaram com picos entre 250 e $600 \mathrm{~nm}$.

Figura 5 - Espectro da lâmpada de Hg utilizada na fotodegradação da SMZ.

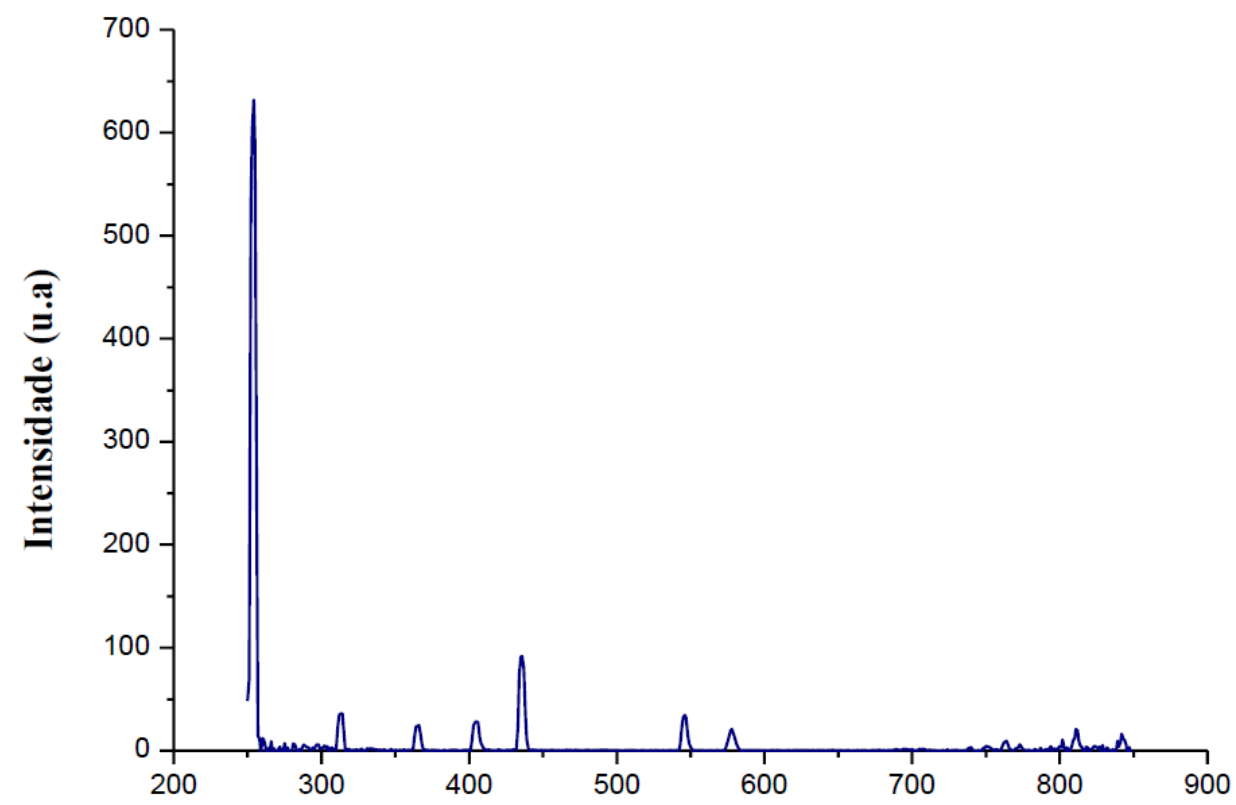

Fonte: FERREIRA, T. C. R., Tese de Doutorado, $2013^{65}$.

As degradações foram efetuadas em soluções preparadas com SMZ em meio aquoso na concentração inicial de $25 \mathrm{mg} \mathrm{L}^{-1}$. Alíquotas foram retiradas em tempos pré-determinados, para avaliar a cinética da degradação, bem como avaliar em qual tempo são gerados maior número e maior concentração de produtos de degradação. A reação foi realizada durante 6 horas e alíquotas foram coletadas nos tempos 0,15 e $30 \mathrm{~min}$, e 1, 2, 4 e 6 h e posteriormente analisadas por LC-MS.

\subsection{Escolha da melhor fase extratora e eluente para os produtos de degradação da sulfametazina}

Esses estudos foram previamente desenvolvidos em trabalho da Dra. Tanare Cambraia Ribeiro Ferreira - FERREIRA, T. C. R., como parte de sua tese de doutorado ${ }^{65}$, executada no Grupo de Pesquisa, cujos objetivos vêm parcialmente ao encontro dos objetivos desse projeto de mestrado, no que diz respeito à identificação e separação de produtos de degradação de antibióticos. O método de extração escolhido por ela para avaliar qual a melhor fase extratora foi a SPE convencional em cartuchos. 
Após a identificação dos tempos onde havia a formação e presença do maior número de produtos de degradação, procedeu-se a avaliação da pré-concentração utilizando os seguintes cartuchos extratores: Strata ${ }^{\mathrm{TM}} \mathrm{X}$, Strata $^{\mathrm{TM}}$ XA, Chromabond ${ }^{\circledR}$ HR-X, Chromabond ${ }^{\circledR}$ HR-XA e Oasis $^{\circledR}$ HLB. Para eluição foram avaliados os seguintes solventes: acetonitrila; acetonitrila acidificada com $5 \% \mathrm{H}_{3} \mathrm{PO}_{4}$; acetonitrila alcalinizada com $5 \% \mathrm{NH}_{4} \mathrm{OH}$; metanol; metanol acidificado com $5 \% \mathrm{H}_{3} \mathrm{PO}_{4}$ e metanol alcalinizado com $5 \% \mathrm{NH}_{4} \mathrm{OH}$. Os cartuchos e os solventes avaliados foram combinados conforme representado na Tabela 3.

Tabela 3 - Cartuchos e solventes avaliados na pré-concentração dos produtos de degradação da sulfametazina

\begin{tabular}{|c|c|c|c|c|c|c|}
\hline \multirow[t]{2}{*}{ Cartuch } & \multirow[b]{2}{*}{ Solventes } & $\overline{\mathbf{A}}$ & $\overline{\mathbf{B}}$ & $\bar{C}$ & $\bar{D}$ & $\mathbf{E}$ \\
\hline & & $\begin{array}{l}\text { Oasis } \\
\text { HLB }\end{array}$ & Strata-X & $\overline{\text { Strata-XA }}$ & $\begin{array}{c}\text { Chromabond } \\
\text { HR-X }\end{array}$ & $\begin{array}{c}\text { Chromabond } \\
\text { HR-XA }\end{array}$ \\
\hline 1 & ACN & A1 & B1 & $\mathrm{C} 1$ & D1 & E1 \\
\hline 2 & $\mathrm{ACN} 5 \% \mathrm{H}_{3} \mathrm{PO}_{4}$ & A 2 & B2 & $\mathrm{C} 2$ & D2 & E2 \\
\hline 3 & $\mathrm{ACN} 5 \% \mathrm{NH}_{4} \mathrm{OH}$ & A3 & B3 & $\mathrm{C} 3$ & D3 & E3 \\
\hline 4 & МeOH & A4 & B4 & $\mathrm{C} 4$ & D4 & E4 \\
\hline 5 & $\mathrm{MeOH} 5 \% \mathrm{H}_{3} \mathrm{PO}_{4}$ & A5 & B5 & $\mathrm{C} 5$ & D5 & E5 \\
\hline 6 & $\mathrm{MeOH} 5 \% \mathrm{NH}_{4} \mathrm{OH}$ & A6 & B6 & C6 & D6 & E6 \\
\hline
\end{tabular}

Fonte: Adaptado de FERREIRA, T. C. R. Tese de Doutorado, $2014^{65}$.

Para a analisar esses resultados, Ferreira ${ }^{65}$ tomou a maior área para cada produto de degradação (obtida a partir do íon extraído) como $100 \%$ e as demais diretamente proporcionais a essa. Para a SMZ inalterada, todas as combinações de fases extratoras e solventes que foram avaliadas obtiveram eficiência relativa superior a 85\%. Quanto aos produtos de degradação, a fase Oasis ${ }^{\circledR}$ HLB combinada com a eluição com metanol obteve a melhor pré-concentração para cinco dos oito compostos avaliados. Com base nos resultados apresentados, a fase Oasis ${ }^{\circledR}$ HLB e a eluição com metanol seguida de eluição com metanol alcalinizado com $5 \% \mathrm{NH}_{4} \mathrm{OH}$ foram selecionados para a pré-concentração dos produtos de degradação e da SMZ inalterada. 


\subsection{Otimização da extração de produtos de degradação da sulfametazina utilizando microextração por sorvente empacotado (MEPS)}

Na extração por MEPS, um dos aspectos mais críticos é o número de ciclos aspirardispensar feitos com a microsseringa, principalmente nas etapas de extração da amostra e de eluição dos compostos de interesse. Para tanto, é necessário otimizar os ciclos dessas etapas, o que foi feito de acordo com a Tabela 4.

Tabela 4 - Experimentos para otimizar os ciclos de extração da amostra e os ciclos de eluição dos compostos de interesse

\begin{tabular}{lcl}
\hline Replicatas & Ciclos Extração & \multicolumn{1}{c}{ Ciclos Eluição } \\
\hline Grupo I & 10 & $20\left(10 \mathrm{MeOH}\right.$ e $\left.10 \mathrm{MeOH}+5 \% \mathrm{NH}_{4} \mathrm{OH}\right)$ \\
Grupo II & 10 & $10\left(5 \mathrm{MeOH}\right.$ e $\left.5 \mathrm{MeOH}+5 \% \mathrm{NH}_{4} \mathrm{OH}\right)$ \\
Grupo III & 5 & $10\left(5 \mathrm{MeOH}\right.$ e $\left.5 \mathrm{MeOH}+5 \% \mathrm{NH}_{4} \mathrm{OH}\right)$ \\
Grupo IV & 5 & $20\left(10 \mathrm{MeOH}\right.$ e $\left.10 \mathrm{MeOH}+5 \% \mathrm{NH}_{4} \mathrm{OH}\right)$ \\
\hline Fo
\end{tabular}

Fonte: Autoria Própria.

Cada grupo apresentado na Tabela 4 foi feito no mínimo em triplicata.

\subsection{Pré-concentração dos produtos de degradação da sulfametazina em água}

Para avaliar a eficiência do método de extração e da fase extratora escolhida em baixas concentrações, aplicou-se um fator de diluição em água de 1:20 partindo-se de amostras coletadas na degradação após $1 \mathrm{~h}$ na concentração de $25 \mathrm{mg} \mathrm{L}^{-1}$. Realizou-se a préconcentração utilizando a seringa de $1000 \mu \mathrm{L}$ e volume de eluição de $50 \mu \mathrm{L}$, tomando-se a amostra não diluída como referência para uma eficiência de $100 \%$.

\subsection{Degradação da sulfametazina em baixa concentração}

Após avaliar a pré-concentração dos produtos de degradação da sulfametazina, procedeu-se uma degradação diretamente na concentração de $0,25 \mathrm{mg} \mathrm{L}^{-1}$. Alíquotas foram coletadas após 30 min de degradação e pré-concentradas conforme estabelecido na préconcentração utilizando a diluição de amostras mais concentradas (seção 3.5).

\subsection{Pré-concentração dos produtos de degradação da sulfametazina em esgoto sintético}

Para avaliar a pré-concentração de produtos de degradação da SMZ em matrizes mais complexas, foi utilizada a diluição de amostras coletadas após $1 \mathrm{~h}$ de degradação em esgoto sintético. Esse meio de esgoto sintético é o mesmo utilizado nos reatores biológicos do 
Laboratório de Processos Biológicos (LPB) da Escola de Engenharia de São Carlos da Universidade de São Pulo (EESC-USP), obtido por meio de parceria científica com o Prof. Dr. Marcelo Zaiat ${ }^{66}$. O meio é composto por extrato de carne, óleo de soja, sacarose, amido solúvel e celulose. Para efeitos comparativos, a pré-concentração foi feita da mesma forma em que foi descrita na Seção 3.5, incluindo-se uma etapa de lavagem com água entre a extração e a eluição dos compostos de interesse, a fim de eliminar eventuais interferentes.

\subsection{Otimização das etapas de lavagem em MEPS}

A fim de evitar que eventuais interferentes possam mascarar resultados da análise cromatográfica, a lavagem se faz necessária quando se utiliza uma matriz mais complexa na amostragem. Nesse caso, a lavagem é feita com água, para eliminar compostos mais polares que os produtos de degradação e deixar esses últimos retidos na fase extratora até a etapa de eluição. O número de ciclos aspirar-dispensar da lavagem deve ser tal para que não deixe interferentes retidos e nem elua compostos de interesse. Dessa forma, foram feitos testes, com no mínimo três replicatas cada, para avaliar 3 e 5 ciclos de aspirar-dispensar, a fim de descobrir qual apresenta maior eficiência e menores perdas dos compostos de interesse.

\subsection{Estudos de efeitos de matriz com produtos de degradação da sulfametazina}

Para analisar os efeitos de matriz do esgoto sintético, foram preparadas três séries de amostras, injetadas no mínimo em triplicata, de acordo com adaptações feitas do protocolo de Matuszewski $^{54}$. A série 1 foi preparada com uma alíquota da degradação da sulfametazina com diluição 1:2 em água. A série 2 foi preparada da mesma forma que a série 1, porém fazendo a diluição 1:2 em esgoto sintético, seguida da extração por MEPS. A alíquota com os produtos de degradação foi adicionada ao esgoto antes da extração na série 2. A série 3 foi preparada também com esgoto sintético numa diluição 1:2, porém, a adição da alíquota com os produtos de degradação foi feita ao esgoto depois deste ter passado pela extração por MEPS. Comparando-se as séries 1 e 3 (Equação 1), é possível ter uma avaliação sobre os efeitos de matriz (ME) que podem vir a interferir nas análises dos produtos de degradação da sulfametazina. Já com a comparação das séries 2 e 3 (Equação 2), pode-se avaliar a recuperação (RE) dos produtos de degradação da sulfametazina em esgoto sintético. A eficiência total (PE) do processo é feita comparando-se as séries 1 e 2 (Equação 3). 


\subsection{Degradação da sulfametazina em baixa concentração utilizando esgoto sintético como matriz}

Sabendo-se dos efeitos de matriz causados pelo esgoto sintético e tendo-se um método desenvolvido para a extração dos produtos de degradação da sulfametazina que é eficiente mesmo em baixas concentrações, seguiu-se a degradação da sulfametazina em baixa concentração diretamente em esgoto sintético. A concentração utilizada foi de $0,25 \mathrm{mg} \mathrm{L}^{-1}$ e o tempo de degradação foi de $30 \mathrm{~min}$. As alíquotas foram pré-concentradas da mesma forma apresentada na seção 3.7.

\subsection{Avaliação de nanotubos de carbono como sorvente para produtos de degradação da sulfametazina}

Nanotubos de carbono múltiplas paredes foram testados devido à sua grande área superficial, que aumenta sua capacidade de adsorção, tornando-os candidatos promissores a sorvente.

Os nanotubos de carbono já vinham sendo aplicados em outros projetos do Grupo de Pesquisa para a extração de antibióticos inalterados. Devido ao sucesso da aplicação nesses casos, eles foram testados também para os produtos de degradação da sulfametazina por MEPS, seguindo os protocolos de extração já estabelecidos para a fase Oasis ${ }^{\circledR}$ HLB.

Foi utilizada uma concentração inicial de sulfametazina mais alta $\left(25 \mathrm{mg} \mathrm{L}^{-1}\right)$, para melhor identificação dos produtos de degradação após a análise cromatográfica. A diluição feita após a degradação foi de 1:20. O número de ciclos aspirar/dispensar foram os mesmos estabelecidos anteriormente para cada etapa da extração por MEPS.

\subsection{Avaliação de etanol absoluto como substituto do metanol na extração dos produtos de degradação da sulfametazina}

Apesar de o etanol não ser a escolha mais óbvia para um solvente em MEPS, o desenvolvimento de protocolos ambientalmente responsáveis, dentro dos conceitos de química verde, o tornam uma possibilidade viável e menos tóxica ao ambiente, se comparado com o metanol.

Para fins de comparação, o protocolo seguido para a extração utilizando etanol foi o mesmo já utilizado com o metanol. Uma solução de $25 \mathrm{mg} \mathrm{L}^{-1}$ de sulfametazina em água foi 
degradada e diluída na razão 1:20 para então ser pré-concentrada por MEPS com os mesmos números de ciclo aspirar/dispensar para cada etapa. O metanol foi substituído por etanol nas etapas de condicionamento, eluição e lavagem da fase extratora.

\subsection{Análise de produtos de degradação da sulfametazina em reator biológico}

Os ensaios de biodegradação de sulfametazina foram realizados em reatores de polietileno de $500 \mathrm{~mL}$ operados em batelada, contendo $400 \mathrm{~mL}$ de volume reacional. Os reatores foram inoculados com lodo anaeróbio granular proveniente de um reator anaeróbio de fluxo ascendente e manta de lodo - UASB (upflow anaerobic sludge blanket) empregado no tratamento de água residuária de um abatedouro de aves. O inóculo foi adicionado para uma concentração final de biomassa de 5 g STV $\mathrm{L}^{-1}$, mantida constante em todos os experimentos.

Os reatores foram alimentados com água residuária sintética complexa simulando efluente de suinocultura (apresentando uma demanda química de oxigênio (DQO) dissolvida de $1500 \mathrm{mg} \mathrm{L}^{-1}$ ), fortificada com concentrações iniciais de fármaco de $5 \mathrm{mg} \mathrm{L}^{-1}$ e $1 \mathrm{mg} \mathrm{L}^{-1}$. Após 48 horas de reação, sacarose em estado sólido foi adicionada aos reatores em concentração correspondente a uma DQO de $1000 \mathrm{mg} \mathrm{L}^{-1}$, com o objetivo de promover a manutenção da atividade microbiana, pois após esse tempo reacional a maioria dos constituintes orgânicos presentes inicialmente já haviam sido degradados (monitoramento feito por análises de DQO).

Os reatores foram mantidos em mesa de agitação orbital a $145 \mathrm{rpm}$ e temperatura constante de $30^{\circ} \mathrm{C}$ por meio de câmara de controle de temperatura. Os ensaios de biodegradação duraram 72 horas. Alíquotas do meio reacional foram retiradas em intervalos de tempo relevantes para obtenção do perfil temporal de remoção de DQO. As amostras foram filtradas em membrana de fibra de vidro de $1,2 \mu \mathrm{m}$.

Um experimento controle, em que não foi adicionado o fármaco, foi realizado nas mesmas condições. Essa parte do experimento foi realizada no Laboratório de Processos Biológicos (LPB) do Departamento de Hidráulica e Saneamento (SHS) da Escola de Engenharia de São Carlos (EESC) em parceria com o aluno de doutorado Guilherme Henrique Duarte de Oliveira, orientado pelo Prof. Dr. Marcelo Zaiat.

As extrações foram feitas com o protocolo de MEPS utilizado para pré-concentração de produtos de degradação em esgoto sintético. 


\subsection{Ciprofloxacino}

A fotodegradação do ciprofloxacino procedeu-se da mesma forma que descrito na seção 3.2, porém a concentração inicial de fármaco utilizada foi de $10 \mathrm{mg} \mathrm{L}^{-1}$ devido a problemas de solubilidade em concentrações maiores que essa.

A avaliação da melhor fase extratora bem como do melhor eluente ocorreu de acordo com o que foi descrito na seção 3.3 para a sulfametazina e também foi executada por Ferreira $^{65}$. Assim como para a sulfametazina, a maior área para cada produto de degradação (obtida a partir do íon extraído) foi considerada como $100 \%$ e as demais diretamente proporcionais a essa. Após o estudo para descobrir quais solventes obtiveram a maior capacidade de eluição para as fases extratoras escolhidas (tanto para os produtos de degradação quanto para o CIP inalterado) procedeu-se a avaliação para selecionar qual combinação de fase extratora e solvente a serem utilizados nos estudos de pré-concentração em baixa concentração. A fase Oasis ${ }^{\circledR}$ HLB e a eluição por etapas com acetonitrila acidificada com $5 \%$ de $\mathrm{H}_{3} \mathrm{PO}_{4}$ e acetonitrila alcalinizada com $5 \%$ de $\mathrm{NH}_{4} \mathrm{OH}$ foram selecionados para a pré-concentração dos produtos de degradação e do CIP inalterado, levando em consideração o conjunto de compostos que deve ser pré-concentrado durante a extração.

Da mesma forma, a pré-concentração tanto em água quanto em esgoto sintético foi feita de acordo com o descrito nas seções 3.5 e 3.7, porém, o tempo de degradação utilizado foi de $20 \mathrm{~min}$, devido ao número de produtos de degradação do ciprofloxacino formados nesse tempo ser maior. A otimização de ciclos de MEPS feita para sulfametazina foi utilizada também para o ciprofloxacino a fim de permitir comparações entre fármacos. As degradações em baixa concentração do ciprofloxacino foram feitas em concentração de $0,10 \mathrm{mg} \mathrm{L}^{-1}$, tanto em água quanto em esgoto sintético. O tempo de degradação em baixa concentração foi de 10 min devido à maior concentração de produtos de degradação nesse tempo. Os estudos de efeito de matriz também foram feitos utilizando as adaptações do protocolo de Matuszewski ${ }^{54}$ como descrito na seção 3.9, guardadas as diferenças de solvente de eluição, concentração inicial de fármaco inalterado e tempo de degradação.

\subsection{HPLC-MS/MS}

Nas análises por HPLC acoplado à espectrometria de massas foi utilizado um sistema LC-ESI-QToF/MS compreendido por HPLC Shimadzu série 20A Prominence equipado com coluna Kinetex XB-C18 (100 mm x 2,1 mm; 2,6 $\mu \mathrm{m})$ da Phenomenex. O volume de injeção 
foi de $5 \mu \mathrm{L}$. Como fase móvel utilizou-se água purificada contendo $0,1 \%$ de ácido fórmico (A) /acetonitrila contendo $0,1 \%$ de ácido fórmico (B) utilizando a seguinte programação: 0-3 min, 5\% de B; 3-12 min, 5-60\% de B; 12-14 min, 60-95\% de B; 14-20 min, 95\% de B; 20-22 min, 95-5\% de B; 22-26 min, 5\% de B. A vazão utilizada foi de $0,25 \mathrm{~mL} \mathrm{~min}^{-1}$ e temperatura do forno de $40^{\circ} \mathrm{C}$. A detecção e análise dos compostos foi feita em um espectrômetro de massas Bruker tipo QToF, modelo micrOTOF-Q II, onde os compostos foram ionizados por electrospray operando no modo positivo, com os seguintes parâmetros: voltagem do capilar de $4,5 \mathrm{kV}$, temperatura de dessolvatação de $200^{\circ} \mathrm{C}$, vazão do gás de secagem de $8 \mathrm{~L} \mathrm{~min}^{-1}$ e pressão do nebulizador de 4 bar. O analisador utilizado foi o Time of Flight (ToF) com intervalo de relação massa/carga (m/z) monitorado de 50 a $3000 \mathrm{u}$, taxa de aquisição de espectros a $2 \mathrm{~Hz}$ no modo full $M S$. Para melhor identificação de alguns produtos formados, alguns experimentos de MS/MS foram realizados. 


\section{RESULTADOS E DISCUSSÃO}

\subsection{Avaliação dos produtos de degradação formados durante a fotólise da sulfametazina na concentração de $25 \mathrm{mg} \mathrm{L}^{-1}$}

A radiação ultravioleta (UV) é amplamente utilizada para desinfecção de água potável devido à sua eficácia contra uma vasta gama de agentes patogênicos. Essa radiação também pode promover a degradação de compostos orgânicos fotolábeis por fotólise direta devido ao seu potencial de absorção ${ }^{67}$.

O ensaio fotoquímico realizado no reator de bancada (Figura 4) através da incidência de radiação UV-C mediante o uso de lâmpada de vapor de mercúrio ( 9 W) degradou totalmente a sulfametazina após 2 horas de reação. Adicionalmente, a maior intensidade dos produtos de degradação foi gerada com 1 hora de reação. Como esperado, os produtos de degradação da sulfametazina são formados aparentemente em concentrações bem menores do que a da molécula inalterada. Todos os íons isolados e monitorados nesse experimento tiveram a sua identidade correlacionada à da molécula inalterada de sulfametazina por Ferreira $^{65}$. As estruturas foram confirmadas por espectros de massa de alta resolução e eventualmente por espectrometria de massas sequencial de alta resolução.

A Tabela 5 apresenta as fórmulas moleculares, a relação massa/carga e as correspondentes estruturas propostas para os produtos de degradação gerados pela fotólise da SMZ em concentração elevada $\left(25 \mathrm{mg} \mathrm{L}^{-1}\right)$. Devido à baixa concentração, suas estruturas foram propostas a partir das fórmulas moleculares obtidas com o auxílio da ferramenta Smart Formula presente no software Data Analysis da Bruker, uma vez que a quantidade de analito disponível não seria suficiente para uma caracterização adicional por espectrometria no infravermelho (FT-IR) ou por ressonância magnética nuclear (NMR).

Todos esses produtos de degradação observados também foram relatados no trabalho de García-Galán ${ }^{68}$. O referido trabalho utilizou uma concentração inicial de SMZ de $40 \mathrm{mg} \mathrm{L}^{-1}$ e promoveu a fotólise em um simulador de luz UV equipado com lâmpada de Xenônio (comprimentos de onda variando de 200-800 nm) por um período de 100 horas. A desulfonização da SMZ também foi relatada como a principal origem dos produtos de degradação e também foram observados picos cromatográficos distintos que corresponderam ao mesmo espectro de massas para $m / z, 215,1297$ e composição elementar $\mathrm{C}_{12} \mathrm{H}_{15} \mathrm{~N}_{4}$. 
Tabela 5 - Estruturas químicas propostas para os produtos de degradação da sulfametazina obtidos pela fotólise

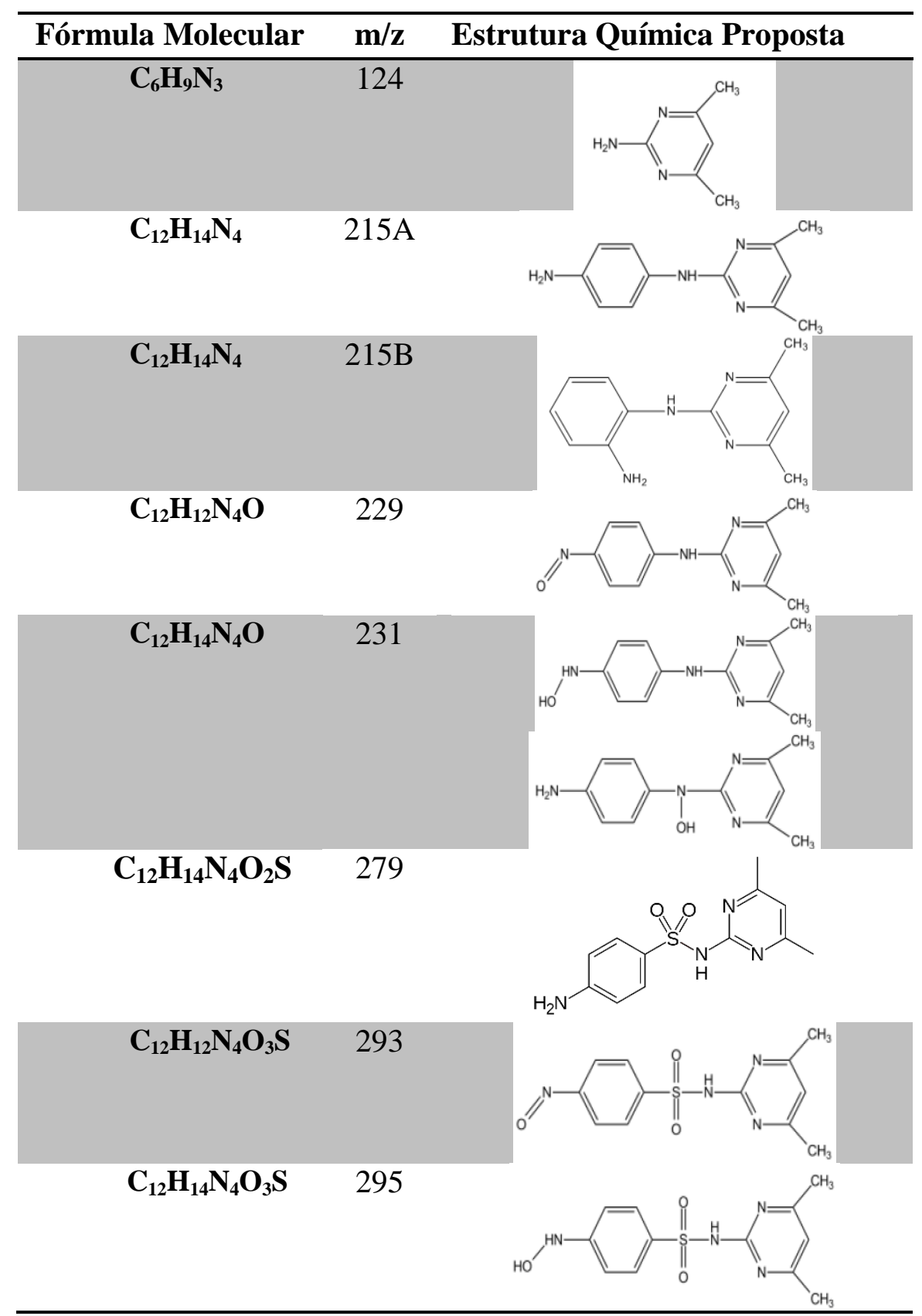

Fonte: Adaptado de FERREIRA, T. C. R., Tese de Doutorado, $2014^{65}$.

\subsection{Otimização da extração de produtos de degradação da sulfametazina por MEPS}

O preparo de amostras utilizando MEPS tem se tornado uma técnica promissora para limpeza e pré-concentração de amostras que serão submetidas à análise cromatográfica. Um atrativo dessa técnica em relação à SPE são os volumes consideravelmente menores de solventes e amostra utilizados durante a extração. O tempo de extração também é menor, se 
for comparado à SPE. No caso de reatores biológicos, nos quais os volumes de amostra disponíveis são pequenos, é pertinente a utilização de MEPS, pois com $10 \mathrm{~mL}$ de amostra pode-se fazer um número considerável de replicatas. Entretanto, mesmo com essas caraterísticas a serem exploradas, a pré-concentração de compostos formados a partir da degradação de fármacos por MEPS não tem sido abordada na literatura científica.

Partindo-se dos estudos prévios feitos com SPE mostrados na seção 4.3, utilizou-se a fase extratora Oasis ${ }^{\circledR}$ HLB e a eluição por etapas com metanol e metanol alcalinizado com 5\% de $\mathrm{NH}_{4} \mathrm{OH}$. A escolha de utilizar metanol alcalinizado após metanol puro foi feita para tentar melhorar a eluição de alguns produtos de degradação, como o composto de $m / z$ 215A.

Com a definição da fase extratora e do solvente de eluição, se fez necessário otimizar o número de ciclos de cada etapa para a realização da extração por MEPS. Utilizando os grupos definidos pela Tabela 4, avaliou-se qual seria o número de ciclos ideal para a extração da amostra e para a eluição dos compostos de interesse. A Tabela 6 apresenta os resultados em porcentagem relativa à maior área do produto de degradação em questão, bem como o coeficiente de variação $(\mathrm{CV})$ em porcentagem.

Tabela 6 - Eficiência relativa (\%) do número de ciclos de extração e eluição em MEPS para extrair produtos de degradação da sulfametazina

\begin{tabular}{lllllllll}
\hline $\mathbf{m} / \mathbf{z}$ & Grupo I & $\mathbf{C V}(\boldsymbol{\%})$ & $\begin{array}{l}\text { Grupo } \\
\text { II }\end{array}$ & $\mathbf{C V ( \% )}$ & $\begin{array}{l}\text { Grupo } \\
\text { III }\end{array}$ & $\mathbf{C V ( \% )}$ & $\begin{array}{l}\text { Grupo } \\
\text { IV }\end{array}$ & $\mathbf{C V ( \% )}$ \\
\hline $\mathbf{1 2 4}$ & 82,2 & 9,81 & 100 & 13,4 & 83,0 & 15,6 & 90,7 & 7,57 \\
$\mathbf{2 3 1}$ & 100 & 14,8 & 48,0 & 19,2 & 36,5 & 22,4 & 45,9 & 12,6 \\
$\mathbf{2 1 5 A}$ & 14,2 & 25,4 & 87,9 & 24,7 & 47,0 & 19,8 & 100 & 14,7 \\
$\mathbf{2 1 5 B}$ & 53,7 & 12,7 & 75,1 & 14,2 & 100 & 17,8 & 94,4 & 15,6 \\
$\mathbf{2 7 9}$ & 85,3 & 3,52 & 100 & 8,27 & 90,4 & 5,13 & 95,7 & 2,56 \\
$\mathbf{2 9 3}$ & 82,2 & 17,5 & 91,3 & 14,1 & 94,3 & 19,7 & 100 & 12,1 \\
\hline *V=coeficiente de variação & & & & & & \\
Fonte: Autoria Própria.
\end{tabular}

Embora haja casos de discrepância, como o produto 215A no Grupo I em relação aos demais grupos, a maioria dos resultados está bem próxima para todos os quatro grupos. Mesmo na Figura 6 nota-se que, excetuando algumas bandas cromatográficas, os cromatogramas do íon total estão bem próximos de se sobrepor. Dessa forma, para decidir qual o grupo de ciclos é o melhor para ser utilizado na extração dos produtos de degradação é preciso analisar o coeficiente de variação $(\mathrm{CV})$. Quanto menor o $\mathrm{CV}$, maior a reprodutibilidade dos resultados obtidos. Analisando-se a Tabela 6, é possível concluir que o Grupo IV apresentou os menores valores de CV, logo esse grupo foi escolhido. Assim, a 
extração da amostra é feita em 5 ciclos e a eluição é feita em 20 ciclos, sendo 10 com metanol puro e 10 com metanol alcalinizado com $5 \%$ de $\mathrm{NH}_{4} \mathrm{OH}$.

Figura 6 - Comparação analítica entre Controle, representante do Grupo I, Grupo II, Grupo III e Grupo IV referente à otimização do número de ciclos em MEPS.

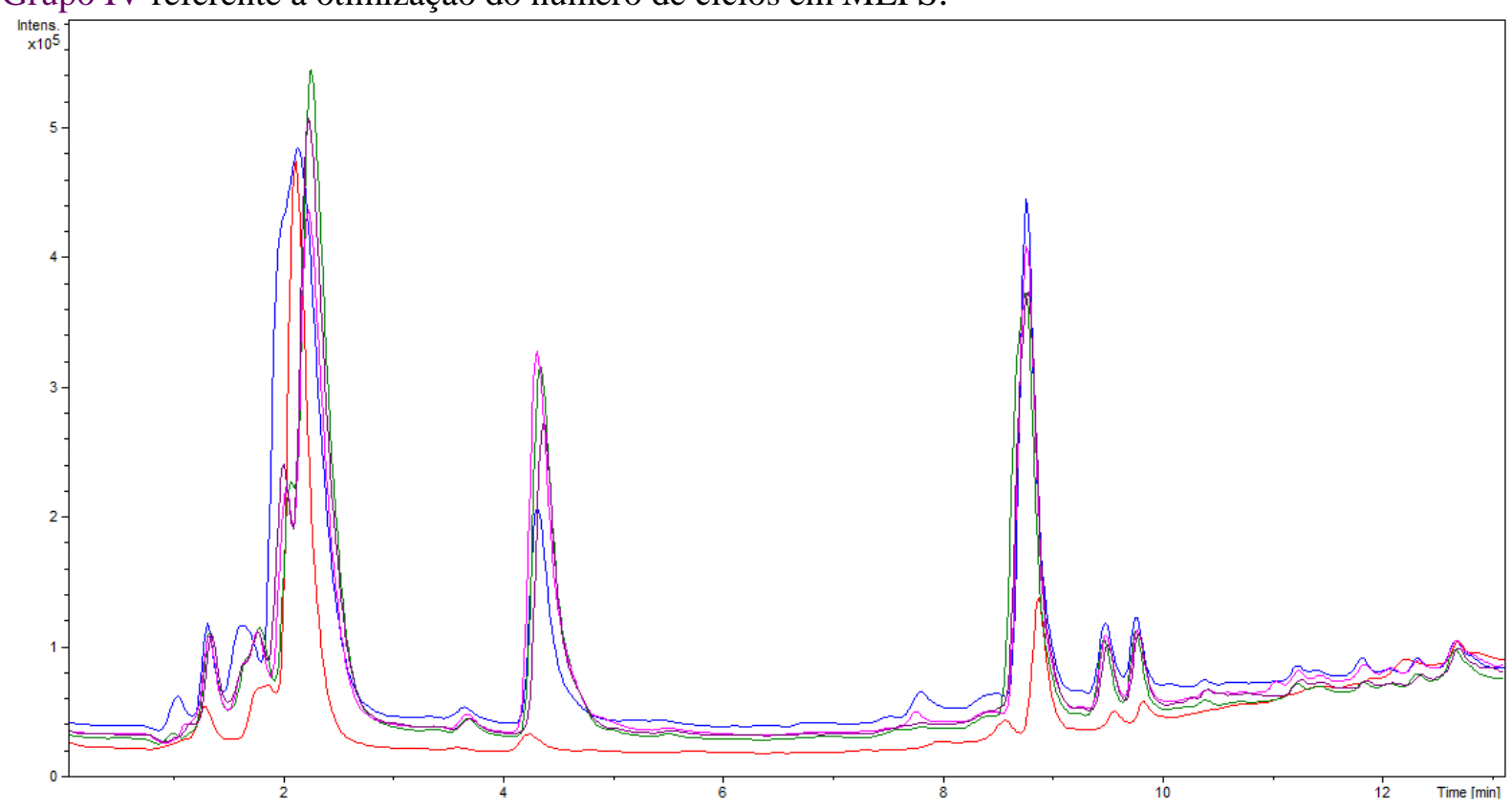

Fonte: Autoria Própria.

Após essa análise de resultados, ficou estipulado que a extração por MEPS teria as etapas mostradas na Figura 7.

Figura 7 - Etapas da extração dos produtos de degradação da sulfametazina.

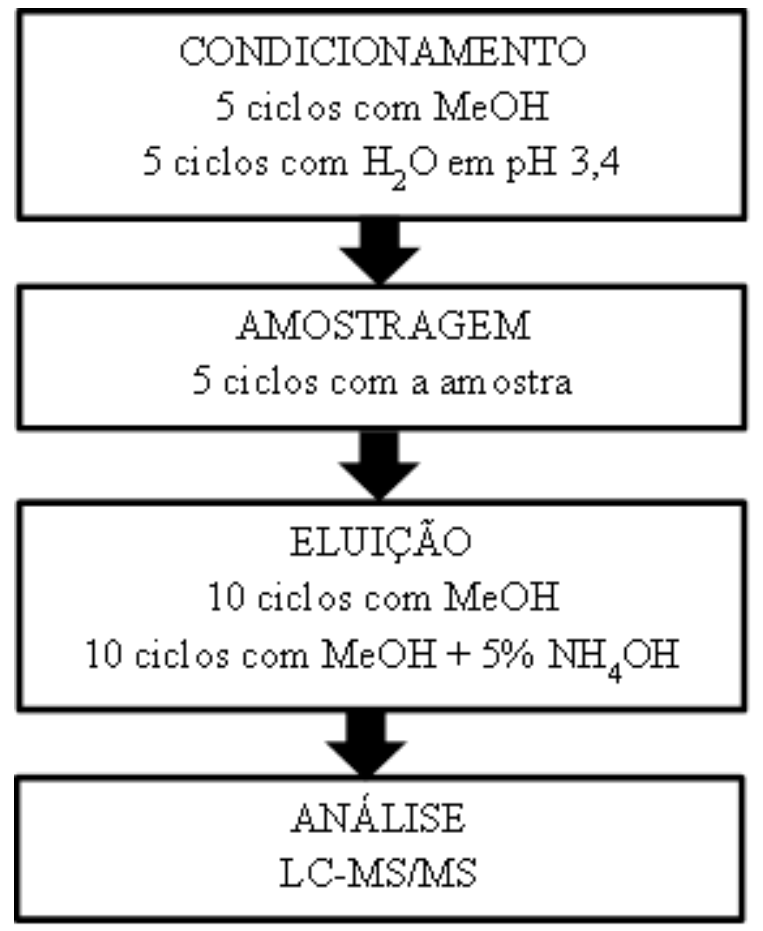

Fonte: Autoria Própria. 
O número de ciclos de condicionamento já havia sido previamente padronizado em outros experimentos realizados no laboratório.

\subsection{Pré-concentração dos produtos de degradação da sulfametazina em água}

Utilizando-se uma microsseringa de $1000 \mu \mathrm{L}$, foram feitos os experimentos de recuperação dos produtos de degradação da sulfametazina em água. A fase extratora utilizada foi Oasis ${ }^{\circledR}$ HLB, da Waters. A eluição foi feita por etapas, com $25 \mu \mathrm{L}$ de metanol puro e $25 \mu \mathrm{L}$ de metanol com $5 \%$ de $\mathrm{NH}_{4} \mathrm{OH}$, totalizando $50 \mu \mathrm{L}$. Dessa forma, foi obtida uma recuperação de 1:20. A amostra não foi submetida à secagem para evitar perdas e maiores erros na estimativa da recuperação. A injeção direta em metanol não alterou significativamente o tempo de retenção e perfil cromatográfico dos compostos.

Tanto os valores de recuperação quanto os coeficientes de variação obtidos são satisfatórios. A recuperação de $119,55 \%$ no intermediário 215B pode ser resultado da eluição com metanol alcalinizado com $5 \%$ de $\mathrm{NH}_{4} \mathrm{OH}$. Esse composto provavelmente possui caráter ácido e, portanto, é facilmente eluído em solvente alcalinizado. Essa diferença na préconcentração do composto de $\mathrm{m} / \mathrm{z}$ 215B fica mais claramente exposta na pré-concentração com MEPS, talvez devido aos ciclos aspirar-dispensar utilizados pela técnica.

Tabela 7 - Pré-concentração dos produtos de degradação de sulfametazina em água, com diluição de 1:20

\begin{tabular}{ccc}
\hline $\mathbf{m} / \mathbf{z}$ & $\mathbf{R e c}(\boldsymbol{\%})$ & $\mathbf{C V}(\boldsymbol{\%})$ \\
\hline $\mathbf{1 2 4}$ & 94,9 & 7,57 \\
$\mathbf{2 3 1}$ & 50,14 & 13,1 \\
$\mathbf{2 1 5 A}$ & 51,35 & 14,74 \\
$\mathbf{2 1 5 B}$ & 119,55 & 5,13 \\
$\mathbf{2 7 9}$ & 105,49 & 6,71 \\
$\mathbf{2 9 3}$ & 104,26 & 1,75 \\
$\mathbf{2 9 5}$ & 99,31 & 10,52 \\
\hline
\end{tabular}

Fonte: Autoria Própria.

* m/z=relação massa/carga; Rec=recuperação; $\mathrm{CV}=$ coeficiente de variação

Nenhum valor de recuperação ficou abaixo de 50\%, o que permite uma identificação confiável desses compostos pela espectrometria de massas. Os valores de CV também ficaram bem abaixo de $30 \%$, que corresponde ao valor máximo geralmente relatados como aceitáveis em métodos para análise de resíduos pela Agência de Proteção Ambiental norte-americana 
(EPA - United States Environmental Protection Agency), um dos mais importantes órgãos de controle ambiental no mundo.

\subsection{Pré-concentração dos produtos de degradação da sulfametazina em baixa concentração}

A fotólise da sulfazetazina $\left(0,25 \mathrm{mg} \mathrm{L}^{-1}\right)$ utilizando reator de bancada (Figura 5) por meio da incidência de radiação UV-C mediante o uso de lâmpada de vapor de mercúrio $(9 \mathrm{~W})$ degradou completamente a sulfametazina após 1 hora (tempo utilizado para retirar as alíquotas na concentração de $25 \mathrm{mg} \mathrm{L}^{-1}$ ). Novamente, os produtos de degradação formados durante a fotólise apresentam concentrações bem menores que a molécula inicial.

Foram encontrados sete produtos de degradação, sendo que seis deles são iguais aos encontrados na degradação realizada em concentração elevada $\left(25 \mathrm{mg} \mathrm{L}^{-1}\right)$. Entretanto o produto de degradação com tempo de retenção de 7,7 min com $\mathrm{m} / z, 229,1074$ (Figura 8) e composição elementar $\mathrm{C}_{12} \mathrm{H}_{13} \mathrm{~N}_{4} \mathrm{O}$ não havia sido detectado nos experimentos anteriores.

O produto de degradação encontrado em maior intensidade é o $\mathrm{m} / z$ 293. Todos os demais possuem máxima intensidade de sinal aos $30 \mathrm{~min}$. Apesar do produto formado em maior concentração $m / z 293$ não ser oriundo da desulfonização da SMZ, essa ainda parece ser uma tendência na fotólise da SMZ mesmo em baixas concentrações.

Uma das incógnitas ao início do projeto era saber se um método otimizado de MEPS conseguiria recuperar os produtos de degradação produzidos diretamente em baixa concentração. Como mostra a Figura 9, o método MEPS conseguiu extrair com êxito os produtos de degradação da sulfametazina produzidos diretamente nessa baixa concentração.

Além disso, a SPE, conhecidamente uma técnica de extração por equilíbrio, não foi capaz de pré-concentrar o produto de degradação $m / z$ 215A, que foi encontrado após a préconcentração com MEPS. Tal fato pode ser explicado pelo método de extração utilizado: com MEPS, são executados diversos ciclos aspirar/dispensar, o que permite um maior contato da matriz e dos analitos com a fase extratora, sendo assim, MEPS é considerada uma técnica de extração por exaustão, ou seja, praticamente todo o analito é retirado da matriz e fica preso à fase extratora.

O êxito dessa extração abre novas possibilidades no campo de análise de produtos de degradação, já que no meio ambiente, as concentrações encontradas desses produtos é baixíssima. Até onde se sabe, os artigos científicos não abordam tal assunto mostrando concentrações tão baixas, devido justamente à dificuldade de pré-concentrar e identificar esses compostos. 
Figura 8 - Cromatograma (íon extraído) do intermediário $\mathrm{m} / \mathrm{z} 229$ encontrados durante a fotólise da $\operatorname{SMZ}\left(0,25 \mathrm{mg} \mathrm{L}^{-1}\right)$ e sua estrutura proposta.

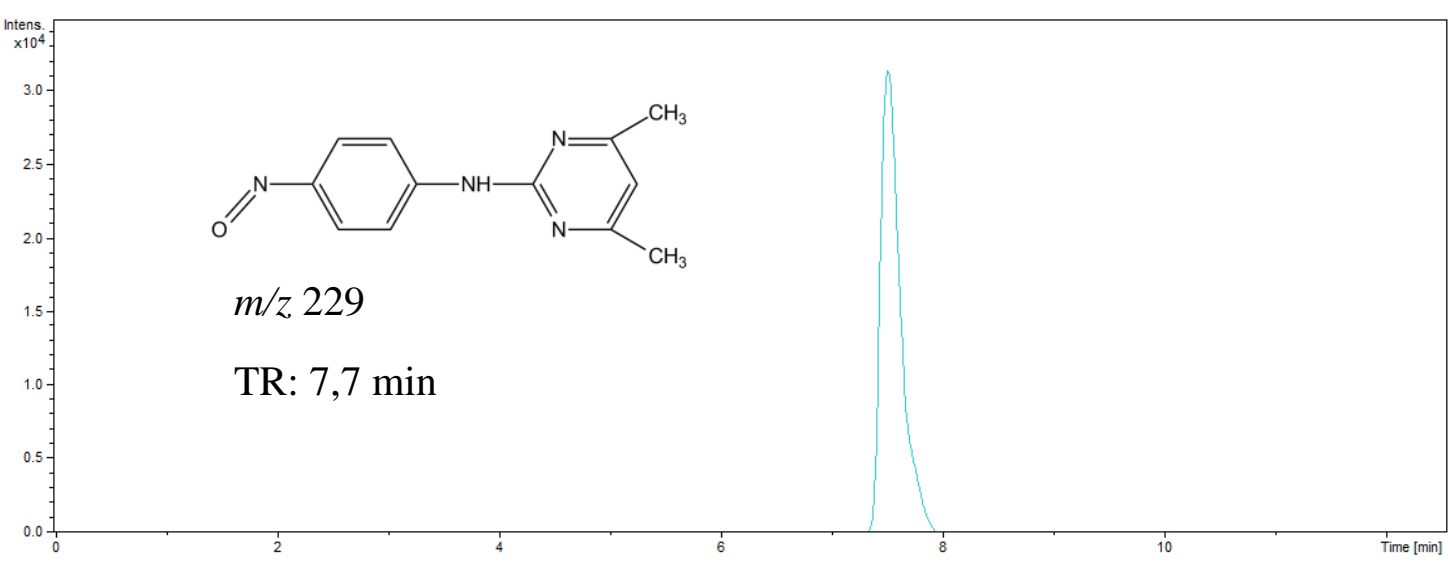

Fonte: FERREIRA, T. C. R., Tese de Doutorado, $2014^{65}$.

Figura 9 - Cromatograma do íon total referente à recuperação por MEPS dos produtos de degradação da sulfametazina em baixa concentração $\left(0,25 \mathrm{mg} \mathrm{L}^{-1}\right)$. Em vermelho, produtos de degradação antes da extração. Em azul, produtos de degradação após a extração.

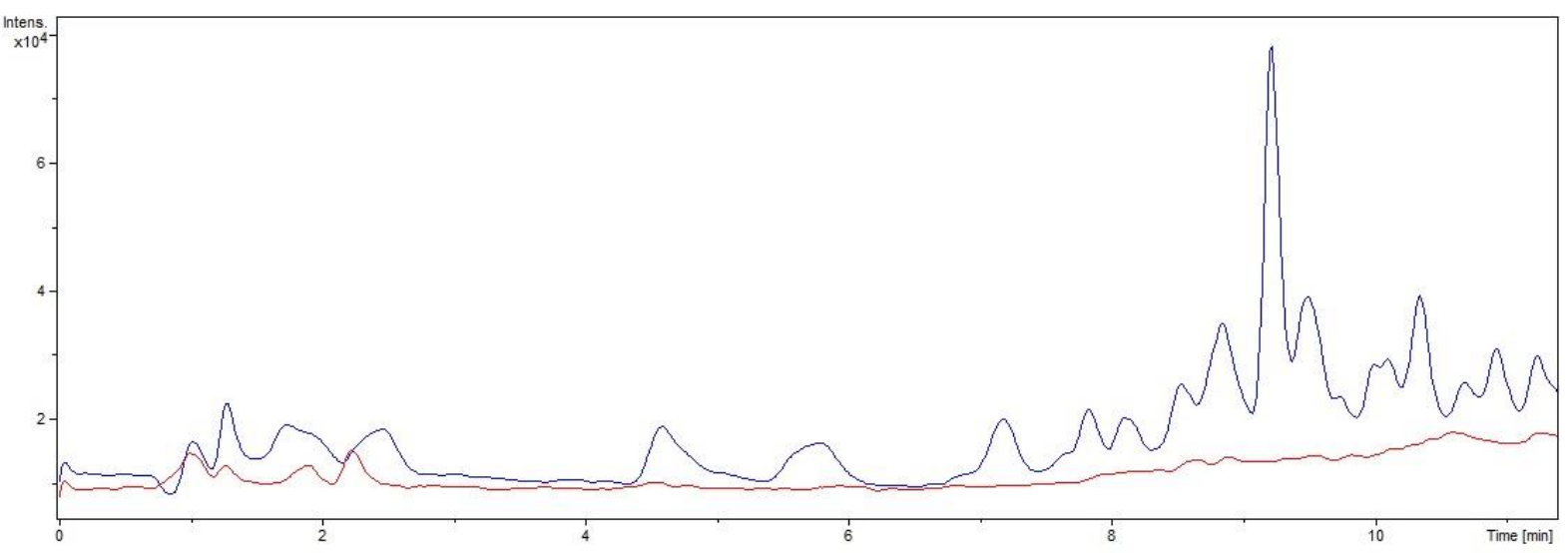

Fonte: Autoria Própria.

\subsection{Otimização da lavagem em MEPS para extração de produtos de degradação em matrizes complexas}

Quando se trabalha com matrizes complexas, como é o caso das amostras de esgoto sintético para recuperação, é necessário que a amostra passe por uma etapa de lavagem com água para eliminar interferentes mais polares que eventualmente ficaram retidos na fase extratora. Como na extração por MEPS o número de ciclos de cada etapa é essencial para o sucesso da extração, foi feito um experimento onde se testava quantos ciclos eram necessários para eliminar os interferentes sem comprometer os produtos de degradação. Foram testados 3 
e 5 ciclos de lavagem. A Tabela 8 apresenta a recuperação e os coeficientes de variação das extrações utilizando 5 ciclos de lavagem, enquanto a Tabela 9 o faz para 3 ciclos de lavagem.

Tabela 8 - Pré-concentração dos produtos de degradação da sulfametazina utilizando 5 ciclos de lavagem

\begin{tabular}{ccc}
\hline $\mathbf{m} / \mathbf{z}$ & $\mathbf{R e c}(\boldsymbol{\%})$ & $\mathbf{C V}(\boldsymbol{\%})$ \\
\hline $\mathbf{1 2 4}$ & 102,57 & 21,31 \\
$\mathbf{2 3 1}$ & 20,22 & 23,25 \\
$\mathbf{2 1 5 A}$ & 21,47 & 22,79 \\
\hline $\mathbf{2 1 5 B}$ & 101,13 & 14,15 \\
$\mathbf{2 9 3}$ & 104,31 & 9,04 \\
$\mathbf{2 9 5}$ & 103,31 & 5,97 \\
$\mathbf{2 7 9}$ & 96,90 & 11,01 \\
\hline
\end{tabular}

Fonte: Autoria Própria.

* m/z=relação massa/carga; Rec=recuperação; $\mathrm{CV}=$ coeficiente de variação

Tabela 9 - Pré-concentração dos produtos de degradação da sulfametazina utilizando 3 ciclos de lavagem

\begin{tabular}{ccc}
\hline $\mathbf{m} / \mathbf{z}$ & $\mathbf{R e c}(\boldsymbol{\%})$ & $\mathbf{C V}(\boldsymbol{\%})$ \\
\hline $\mathbf{1 2 4}$ & 106,58 & 3,45 \\
$\mathbf{2 3 1}$ & 21,83 & 5,54 \\
$\mathbf{2 1 5 A}$ & 24,56 & 15,89 \\
$\mathbf{2 1 5 B}$ & 102,72 & 8,66 \\
$\mathbf{2 9 3}$ & 103,84 & 6,75 \\
$\mathbf{2 9 5}$ & 106,59 & 10,22 \\
$\mathbf{2 7 9}$ & 101,09 & 8,49 \\
\hline
\end{tabular}

Fonte: Autoria Própria.

* m/z=relação massa/carga; Rec=recuperação; $\mathrm{CV}=$ coeficiente de variação

Analisando as Tabelas 8 e 9, nota-se que 3 ciclos de lavagem apresentaram melhores resultados do que 5 ciclos, pois apresentaram um $\mathrm{CV}$ menor na maioria dos produtos de degradação, além de valores de recuperação sutilmente maiores do que 5 ciclos de lavagem. Esses valores podem ser justificados se for considerado que com 5 ciclos de lavagem, alguns analitos de interesse podem ter sido eluídos juntamente com os interferentes. Como os analitos de interesse são polares, eles podem ter sido solubilizados pela água de lavagem, mesmo que em pequenas quantidades, porém suficiente para alterar os valores de recuperação e CV. Além disso, a maior quantidade de ciclos também pode ter carreado pequenas quantidades de analito por atrito mecânico. 


\subsection{Pré-concentração dos produtos de degradação da sulfametazina em esgoto sintético}

A recuperação dos produtos de degradação de sulfametazina em esgoto sintético foi feita da mesma forma que em água, porém a diluição da amostra foi feita com esgoto sintético, mesmo meio utilizado no reator biológico desenvolvido pelo Prof. Zaiat, da EESC. Devido aos interferentes presentes no meio, adicionou-se uma etapa de lavagem (3 ciclos) com água entre a amostragem e a eluição.

Comparando-se os valores da Tabela 7 e da Tabela 10, nota-se que há uma diferença acentuada entre os valores de recuperação dos intermediários de relação $\mathrm{m} / \mathrm{z}$, 124, 231 e $215 \mathrm{~A}$ o que sugere que a matriz interfere na extração e na identificação por espectrometria de massas. Os tempos de retenção durante a corrida cromatográfica permaneceram os mesmos daqueles obtidos na recuperação em água.

Tabela 10 - Pré-concentração dos produtos de degradação de sulfametazina em esgoto sintético, com diluição de 1:20

\begin{tabular}{ccc}
\hline $\mathbf{m} / \mathbf{z}$ & $\mathbf{R e c}(\boldsymbol{\%})$ & $\mathbf{C V}(\boldsymbol{\%})$ \\
\hline $\mathbf{1 2 4}$ & 119,57 & 2,82 \\
$\mathbf{2 3 1}$ & 20,23 & 6,60 \\
$\mathbf{2 1 5 A}$ & 25,58 & 14,25 \\
$\mathbf{2 1 5 B}$ & 122,53 & 8,28 \\
$\mathbf{2 9 3}$ & 104,31 & 4,88 \\
$\mathbf{2 9 5}$ & 103,31 & 13,52 \\
$\mathbf{2 7 9}$ & 100,58 & 5,54 \\
\hline assa/carga; Rec=recuperação; $\mathrm{CV}=$ coeficiente de variação
\end{tabular}

Fonte: Autoria Própria.

* m/z=relação massa/carga; Rec=recuperação; $C V=$ coeficiente de variação

\subsection{Pré-concentração dos produtos de degradação da sulfametazina em baixa concentração utilizando esgoto sintético como matriz}

Com o objetivo de aproximar-se progressivamente de uma amostra real, foi feita a fotólise da sulfametazina em baixa concentração $\left(0,25 \mathrm{mg} \mathrm{L}^{-1}\right)$ utilizando esgoto sintético como meio. Dessa forma, a incidência de radiação da lâmpada de mercúrio também afetará os constituintes do esgoto, e isso poderia provocar alguma alteração nos produtos de degradação, bem como nos interferentes.

A Figura 10 apresenta uma comparação das corridas cromatográficas de uma alíquota que não passou por pré-concentração (em vermelho) e de uma alíquota que foi préconcentrada através do mesmo método utilizado nas outras seções dessa dissertação. 
O cromatograma permite analisar a importância da pré-concentração para identificar os produtos de degradação em baixa concentração em um meio com interferentes, como o esgoto sintético. No cromatograma em que a amostra não foi pré-concentrada, em vermelho, há uma banda cromatográfica com TR 1,0 min constituída por compostos exógenos aos compostos de interesse, ou seja, interferentes provenientes do esgoto sintético.

É possível concluir-se isso numa simples comparação com a Figura 10, na qual a degradação em baixa concentração foi feita em água e a banda cromatográfica em questão não está presente. Além disso, comparando-se com os resultados apresentados por Ferreira ${ }^{65}$, é possível observar uma semelhança entre os resultados. Nesta tese, sem a pré-concentração, apenas a sulfametazina inalterada e o produto de degradação $\mathrm{m} / \mathrm{z}$ 215A (TR 2,5 min) foram detectados, fato que se repetiu nos resultados dessa dissertação.

Figura 10 - Cromatograma do íon total referente à recuperação por MEPS dos produtos de degradação da sulfametazina em baixa concentração $\left(0,25 \mathrm{mg} \mathrm{L}^{-1}\right)$ em esgoto sintético. Em vermelho, produtos de degradação que não passaram por extração. Em azul, produtos de degradação após a extração.

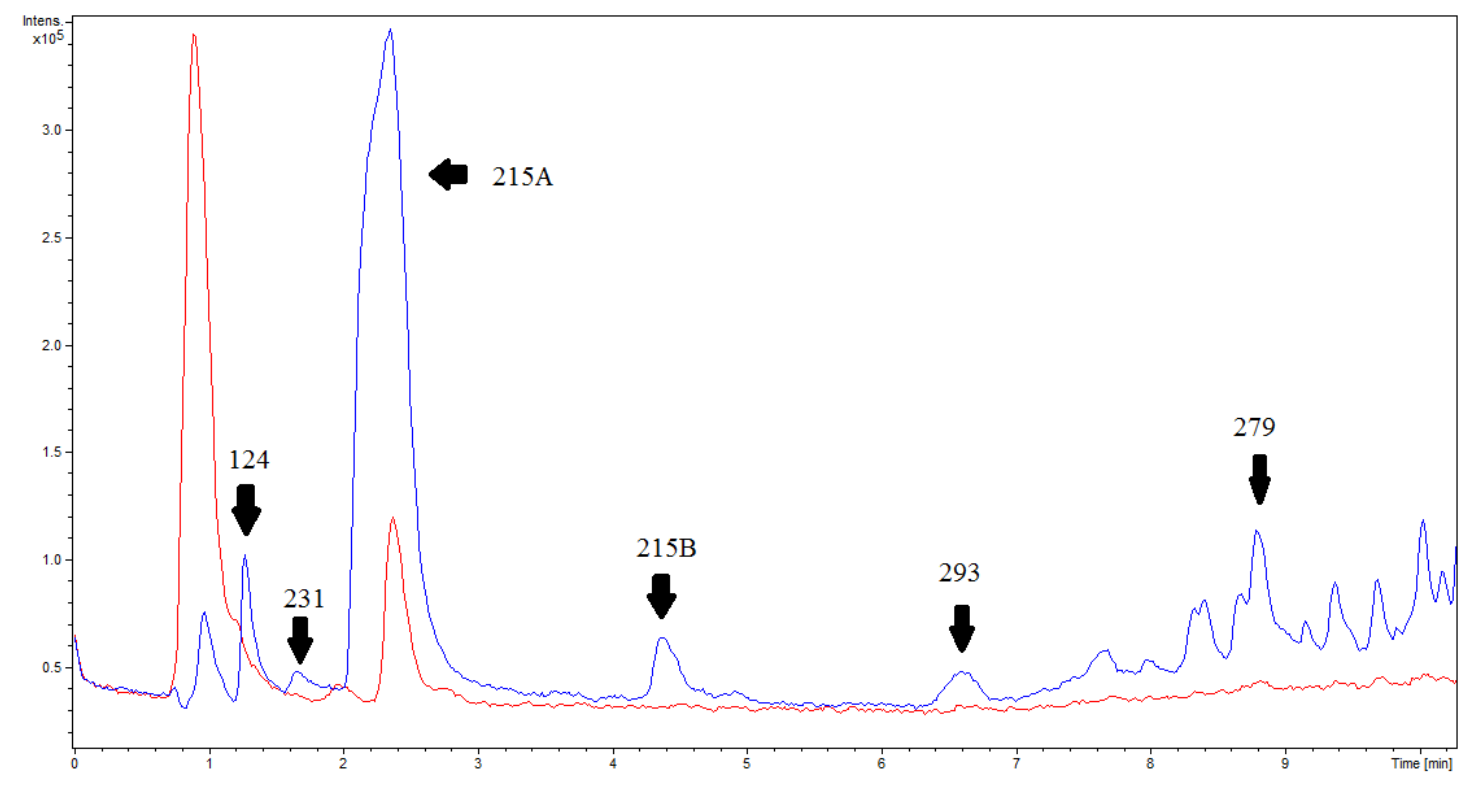

Fonte: Autoria Própria.

Após passar pela pré-concentração e consequente etapa de lavagem, alguns produtos de degradação foram detectados, com exceção dos produtos de $m / z 295 \mathrm{e} \mathrm{m} / z$ 229. A banda cromatográfica de interferentes em 1,0 min foi eliminada quase que totalmente na etapa de lavagem e, com isso, foi possível detectar o produto $\mathrm{m} / \mathrm{z} 124$ (TR 1,3 $\mathrm{min}$ ). A banda cromatográfica correspondente ao produto $\mathrm{m} / z$ 215A (TR 2,5 min) também teve um aumento 
significativo de sinal e é possível ver no cromatograma feito após a pré-concentração as bandas cromatográficas dos outros produtos que foram detectados.

Dessa forma, é possível perceber que mesmo que os produtos não sejam detectáveis numa amostra que não foi pré-concentrada, é aconselhável que seja feito um preparo de amostra eficiente para comprovar a presença ou ausência dos analitos. No caso da sulfametazina e seus produtos de degradação, os analitos estavam sendo mascarados pelos interferentes da matriz ou não estavam em uma concentração que permitisse sua detecção. Com a pré-concentração por MEPS, os ciclos aspirar/dispensar permitiram um maior contato entre os analitos e a fase extratora, fazendo com que eles fossem extraídos da matriz com êxito. Já a etapa de lavagem diminuiu consideravelmente a presença de interferentes da matriz que mascaravam a presença dos produtos de degradação. Logo, um preparo de amostra eficiente, com fase extratora e eluentes adequados aos analitos de interesse é essencial para o êxito da análise cromatográfica, principalmente se os analitos estiverem em baixa concentração.

\subsection{Estudos de efeitos de matriz na análise de produtos de degradação da sulfametazina}

Conforme os estudos vão se aproximando de amostras reais, é necessário saber como uma matriz mais complexa, como o esgoto sintético, pode interferir na pré-concentração, na análise cromatográfica e na detecção por espectrometria de massas.

O esgoto sintético é um eletrólito no qual estão presentes diversos sais e matéria orgânica, o que pode alterar tanto a retenção dos compostos de interesse na fase extratora, quanto a ionização desses compostos numa fonte de espectrômetro de massas. Apesar de uma limpeza eficiente durante o processo de extração, muitas vezes pode ocorrer uma diminuição da ionização dos compostos de interesse devido à competição com interferentes na fonte do espectrômetro de massas. Esse efeito é chamado de supressão de ionização. O efeito contrário também pode ocorrer, e o interferente pode aumentar a ionização do composto de interesse.

Portanto, é fundamental conhecer se esses efeitos de matriz existem durante uma análise para que os resultados possam ser discutidos de maneira efetiva. O protocolo utilizado para os estudos de efeitos de matriz para os produtos de degradação da sulfametazina foi adaptado de Matuszewski ${ }^{54}$, conforme descrito na seção 3.9. Essas adaptações foram feitas porque quando se trabalha com degradação, não há padrões para os produtos que serão gerados durante a reação. Dessa forma, padrões internos e curvas analíticas, que geralmente ajudam a montar um estudo de efeito de matriz efetivo, não são alternativas viáveis. 
A Tabela 11 apresenta o resultado de efeito de matriz (ME), recuperação (RE) e eficiência de processo (PE) de acordo com o protocolo descrito na seção 3.9.

Analisando os resultados apresentados pela Tabela 11, nota-se que o efeito de matriz apareceu principalmente nos compostos de $\mathrm{m} / \mathrm{z}$ 231, 215A, 215B e 295. Os produtos que apresentaram efeito de matriz acima de $100 \%$ são submetidos, teoricamente, a um aumento na ionização quando na presença de esgoto sintético. O único composto que apresentou supressão de ionização foi $\mathrm{m} / \mathrm{z} 295$, o que é interessante se for relacionado com o fato de ter sido um dos únicos produtos de degradação que não foram detectados na degradação em baixa concentração diretamente em esgoto sintético.

Tabela 11 - Efeito de matriz, recuperação e eficiência do processo para produtos de degradação da sulfametazina em esgoto sintético

\begin{tabular}{cccc}
\hline $\mathbf{m} / \mathbf{z}$ & ME (\%) & RE (\%) & PE (\%) \\
\hline $\mathbf{1 2 4}$ & 103,92 & 84,55 & 87,86 \\
$\mathbf{2 3 1}$ & 110,72 & 26,89 & 29,77 \\
$\mathbf{2 1 5 A}$ & 114,34 & 53,97 & 61,71 \\
$\mathbf{2 1 5 B}$ & 120,47 & 62,81 & 75,67 \\
$\mathbf{2 9 3}$ & 103,68 & 93,26 & 96,69 \\
$\mathbf{2 9 5}$ & 71,15 & 94,86 & 67,49 \\
$\mathbf{2 7 9}$ & 103,64 & 102,11 & 105,83 \\
\hline
\end{tabular}

* m/z=relação massa/carga; ME=efeito de matriz; $\mathrm{RE}=$ recuperação; PE=eficiência total do processo Fonte: Autoria Própria.

Aparentemente, a recuperação apresentou valores um pouco diferentes se comparados àqueles apresentados na Tabela $\mathbf{1 0}$ e isso pode ser explicado pelo próprio efeito de matriz e pelas adaptações que tiveram de ser feitas no protocolo experimental. É preciso lembrar que não há padrões analíticos dos produtos de degradação, logo não houve como fazer soluções padrão cuja concentração fosse exatamente conhecida. As concentrações utilizadas para os experimentos foram obtidas por meio da diluição de uma solução padrão de sulfametazina (feita com padrão analítico) que foi degradada pela fotólise (alterando a concentração da sulfametazina para gerar os produtos de degradação em concentração não exatamente conhecida). A eficiência do processo apresentou valores inferiores a 50\% somente para o composto de $m / z$ 231, que já apresentou baixa recuperação em análises anteriores, principalmente quando há presença de esgoto sintético na matriz. 


\subsection{Pré-concentração dos produtos de degradação da sulfametazina utilizando nanotubos de carbono como fase extratora}

Os nanotubos de carbono foram empregados como fase extratora devido à sua grande área superficial e capacidade de adsorção, provenientes da sua estrutura altamente porosa e oca. Essas propriedades o tornam um promissor candidato a sorvente. O objetivo de testar os nanotubos de carbono de múltiplas paredes como possível fase extratora para a sulfametazina e seus produtos de degradação foi investigar um material novo que já apresentou êxito na extração de sulfonamidas em outro projeto de nosso Grupo de Pesquisa. Os resultados estão apresentados na Tabela 12.

Tabela 12 - Pré-concentração dos produtos de degradação de sulfametazina utilizando nanotubos de carbono como fase extratora, com diluição 1:20

\begin{tabular}{ccc}
\hline $\mathbf{m} / \mathbf{z}$ & $\operatorname{Rec}(\boldsymbol{\%})$ & $\mathbf{C V}(\boldsymbol{\%})$ \\
\hline $\mathbf{1 2 4}$ & 18,85 & 20,88 \\
$\mathbf{2 3 1}$ & 21,56 & 9,99 \\
$\mathbf{2 1 5 A}$ & 6,05 & 10,89 \\
$\mathbf{2 1 5 B}$ & 41,83 & 14,80 \\
$\mathbf{2 7 9}$ & 42,65 & 5,62 \\
$\mathbf{2 9 5}$ & 48,08 & 26,79 \\
$\mathbf{2 9 3}$ & 36,86 & 8,61 \\
\hline \multicolumn{3}{c}{ sarga; Rec=recuperação; $\mathrm{CV}=$ coeficiente de variação }
\end{tabular}

Fonte: Autoria Própria.

* m/z=relação massa/carga; Rec=recuperação; $C V=$ coeficiente de variação

Os valores de recuperação para os produtos de degradação da sulfametazina utilizando nanotubos de carbono como fase extratora foram bem inferiores àqueles obtidos com a fase Oasis ${ }^{\circledR}$ HLB. Nenhum dos compostos teve recuperação acima de $50 \%$, o que torna a extração ineficiente. O coeficiente de variação entre as extrações ficou um pouco acima daqueles encontrados para a fase extratora Oasis ${ }^{\circledR}$ HLB. A Figura 11 mostra, sobrepostos, cromatogramas da amostra sem pré-concentração, eluato da pré-concentração, amostra residual (matriz) após passar pelo dispositivo de extração e uma injeção após lavar a fase extratora com metanol puro.

Os cromatogramas da Figura 11 permitem concluir que grande parte dos analitos ficaram adsorvidos na fase extratora. No cromatograma em vermelho, correspondente à alíquota que não passou por extração, é possível identificar as bandas cromatográficas correspondentes aos produtos de degradação, já que a degradação foi feita utilizando uma 
concentração alta de sulfametazina $\left(25 \mathrm{mg} \mathrm{L}^{-1}\right)$. No cromatograma em azul, que corresponde à alíquota que foi submetida à extração com nanotubos de carbono, é possível ver que poucas bandas cromatográficas aparecem e sempre em menor intensidade do que aquelas da amostra que não passou pela etapa da extração. No cromatograma em magenta (parte residual da amostra que passou por extração), é possível notar que exceto por uma pequena banda cromatográfica de TR 2,5 min, correspondente ao produto de $\mathrm{m} / \mathrm{z} 215 \mathrm{~A}$, os analitos foram adsorvidos pela fase extratora, pois não restaram na matriz que passou pelo dispositivo de extração. Já o cromatograma em verde corresponde à uma injeção feita após a lavagem da fase extratora com metanol após a eluição dos analitos de interesse.

Figura 11 - Cromatograma do íon total referente à recuperação por MEPS dos produtos de degradação da sulfametazina em alta concentração $\left(25 \mathrm{mg} \mathrm{L}^{-1}\right)$ em água, utilizando nanotubos de carbono como fase extratora. Em vermelho, produtos de degradação que não passaram por extração. Em magenta, alíquota residual após passar por extração. Em azul, produtos de degradação após a extração. Em verde, fase extratora após lavagem.

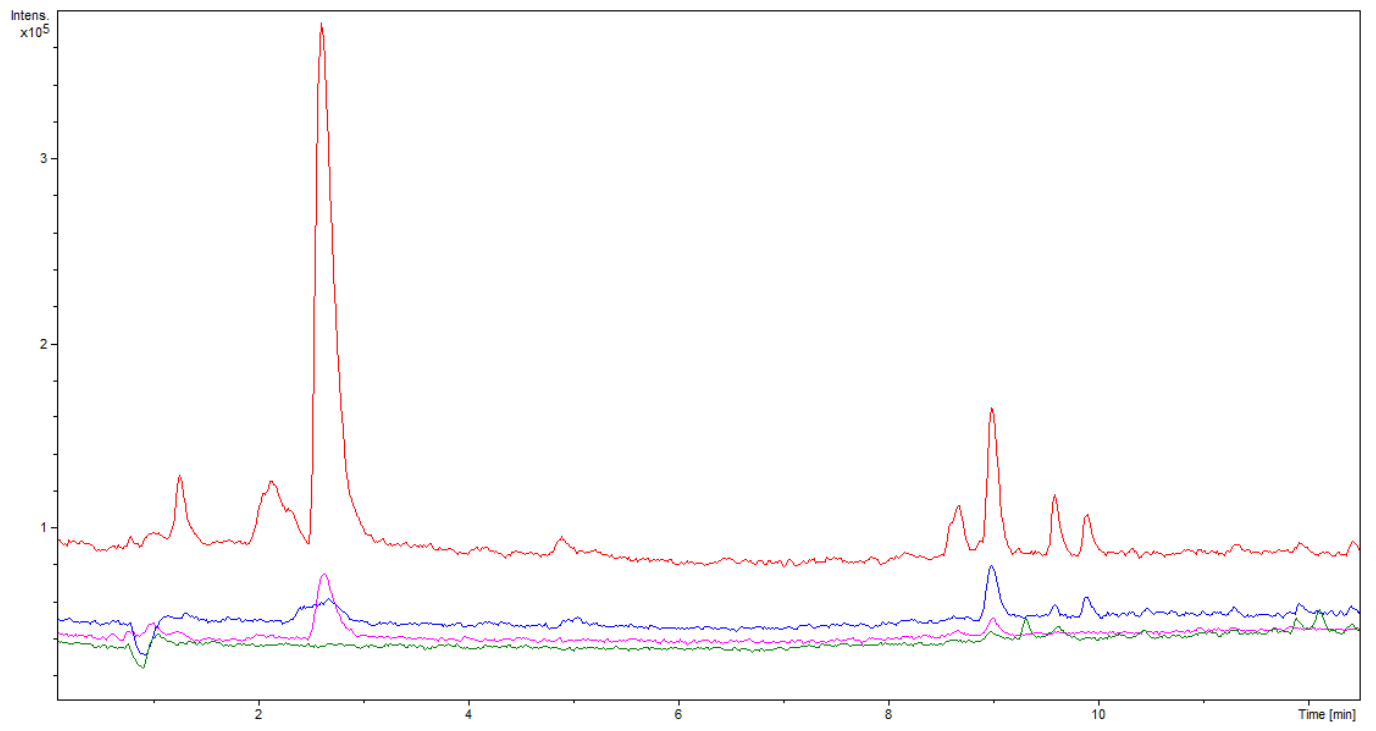

Fonte: Autoria Própria.

Esses quatro cromatogramas sobrepostos comprovam que os analitos tiveram uma grande afinidade pelos nanotubos de carbono, de forma que nem uma grande quantidade de solvente habitualmente utilizado para sua eluição foi capaz de quebrar as interações entre os analitos e a fase extratora.

Dessa forma, pode-se dizer que os nanotubos de carbono possuem uma grande afinidade pelos analitos de interesse, fato que nesse caso não foi positivo, pois nem os 
solventes habitualmente utilizados para a eluição (metanol puro e metanol alcalinizado com $5 \%$ de $\mathrm{NH}_{4} \mathrm{OH}$ ) foram capazes de quebrar as interações. Devido às modificações já feitas no $\mathrm{pH}$ de uma das etapas da eluição, não foram feitos outros testes modificando o $\mathrm{pH}$ do solvente. Talvez uma modificação na polaridade do solvente consiga aumentar a eluição dos analitos, porém, quando se passar para matrizes mais complexas, podem haver problemas na execução da etapa de lavagem. Uma sugestão que fica para próximos trabalhos é a modificação da superfície dos nanotubos de carbono, de forma a diminuir a interação entre analito e fase extratora para que o solvente de eluição consiga removê-lo no momento apropriado.

\subsection{Pré-concentração dos produtos de degradação da sulfametazina substituindo metanol por etanol anidro}

Os microdispositivos de extração, como aquele utilizado em MEPS, têm uma estreita relação com a química ambientalmente responsável, ou química verde, como convencionouse chamá-la. Nesse ramo da química, as pequenas quantidades de solventes, fases extratoras e amostras têm a função de causar o menor dano possível ao meio ambiente, além da óbvia diminuição nos gastos, sem afetar a qualidade das análises e respectivos resultados gerados.

Utilizando-se o microdispositivo de extração de MEPS para os produtos de degradação da sulfametazina, faz-se uso de apenas $2 \mathrm{mg}$ de fase extratora e não mais do que $3 \mathrm{~mL}$ de metanol por extração. Porém, o metanol é um álcool extremamente nocivo, que se manuseado sem os devidos equipamentos de proteção individual (EPI) pode causar sérios danos à saúde dos analistas a curto e longo prazo. Pensando tanto no meio ambiente quanto na segurança, foram feitos experimentos substituindo o metanol por etanol anidro nas etapas de condicionamento, eluição e lavagem na extração de produtos de degradação da sulfametazina. Os resultados da pré-concentração dos produtos de degradação da sulfametazina utilizando etanol como solvente estão apresentados na Tabela 13.

A Tabela 13 mostra que o etanol teve um desempenho abaixo do metanol como eluente, mas alguns valores foram promissores. Exceto pelos produtos de $m / z 231$ e $215 \mathrm{~A}$, que apresentaram taxa de recuperação bem abaixo do indicado, todos os outros produtos de degradação e a sulfametazina inalterada apresentaram recuperação acima de $70 \%$. Esses produtos que apresentaram recuperação muito baixa, também já haviam apresentado taxas de recuperação por volta de $50 \%$ com metanol. 
Tabela 13 - Pré-concentração dos produtos de degradação de sulfametazina (com diluição 1:20) utilizando etanol como solvente em substituição ao metanol

\begin{tabular}{ccc}
\hline $\mathbf{m} / \mathbf{z}$ & $\mathbf{R e c}(\%)$ & $\mathbf{C V}(\boldsymbol{\%})$ \\
\hline $\mathbf{1 2 4}$ & 77,93 & 20,32 \\
$\mathbf{2 3 1}$ & 13,15 & 2,51 \\
$\mathbf{2 1 5 A}$ & 13,67 & 2,79 \\
$\mathbf{2 1 5 B}$ & 120,89 & 11,66 \\
$\mathbf{2 9 5}$ & 86,31 & 10,51 \\
$\mathbf{2 7 9}$ & 74,64 & 1,97 \\
$\mathbf{2 9 3}$ & 101,41 & 7,43 \\
\hline sa/carga; Rec=recuperação; $\mathrm{CV}=$ coeficiente de variação
\end{tabular}

Fonte: Autoria Própria.

* m/z=relação massa/carga; Rec=recuperação; $\mathrm{CV}=$ coeficiente de variação

No caso do produto $m / z 231$, o etanol causou um alargamento da banda cromatográfica que impossibilitou a quantificação completa desse composto. Os coeficientes de variação foram baixos, uma vez que foram abaixo de $15 \%$ para quase todos os analitos (exceto o produto $m / z$ 124), mostrando que as extrações são reprodutíveis.

Etanol e metanol possuem pequenas diferenças em suas moléculas, sendo que o etanol possui uma cadeia carbônica maior que o metanol em uma unidade de carbono. Isso confere uma polaridade menor ao etanol, porém esse continua sendo considerado um solvente polar, mas de menor polaridade que o metanol. O etanol também é considerado um solvente de maior viscosidade que o metanol, devido ao tamanho de sua cadeia carbônica, e esse pode ser um dos fatores que causaram alargamento de banda cromatográfica. Além disso, o etanol é menos tóxico tanto para o ambiente quando para o analista. Apesar de provocar alargamento de banda e devido às suas vantagens, o etanol deve, em trabalhos futuros, ser melhor estudado e explorado como solvente em métodos de extração, pois os resultados que foram obtidos são promissores e talvez possam ser corrigidos com pequenas modificações no método.

\subsection{Análise dos intermediários de sulfametazina em efluente de reator biológico}

Após analisar a recuperação dos produtos de degradação da SMZ no esgoto sintético, avançou-se para o próximo passo numa escala para aplicação do método em amostras reais. Numa colaboração com o Prof. Marcelo Zaiat, do Laboratório de Processos Biológicos, da EESC-USP, conseguiu-se amostras de efluente de reator biológico onde a sulfametazina foi degradada. É importante frisar aqui que as degradações químicas e biológicas tendem a ser diametralmente diferentes, pois numa degradação biológica deve-se levar em consideração as enzimas e compartimentos subcelulares presentes no microrganismo usado na degradação anaeróbica. Enquanto na degradação química, a perda de um grupo funcional da molécula é 
mais comum, na degradação biológica a molécula de sulfametazina pode sofrer transformações mais severas, além da adição de grupos funcionais que não estão originalmente presentes no meio. Portanto, não é esperado que sejam encontrados todos os produtos de degradação química numa amostra de degradação biológica, porém é oportuno descobrir se o método utilizado até então para analisar os produtos de uma degradação química se aplica também a produtos biológicos, uma vez que métodos direcionados para essas aplicações específicas são ainda mais complicados de serem desenvolvidos.

Apesar das diferenças, foi encontrado um produto da degradação química no efluente do reator biológico, ele corresponde ao produto de $\mathrm{m} / \mathrm{z}$ 295, onde a molécula de SMZ sofreu a adição de um grupo hidroxila. Também foi achado um metabólito (originado da degradação biológica) de relação $\mathrm{m} / z 227(\mathrm{M}+2 \mathrm{H})^{2+}$, que corresponde à uma conjugação da $\mathrm{SMZ}$ com uma molécula de glicose. Esse tipo de conjugação pode ser esperado em um reator biológico, já que o microrganismo utiliza a glicose como fonte energética e, portanto, geralmente a tem presente em seu citosol e em compartimentos subcelulares. O fármaco inalterado $(\mathrm{m} / \mathrm{z} 279)$ também foi identificado em todas as alíquotas coletadas, como esperado. Na Tabela 14, podem ser vistos os produtos de degradação que foram encontrados no efluente do reator biológico, bem como após quantas horas de degradação eles foram identificados.

Tabela 14 - Presença de produtos de degradação da sulfametazina no efluente de reator biológico (reator em batelada)

\begin{tabular}{cccccc}
\hline $\mathbf{m} / \mathbf{z}$ & $\mathbf{0 h}$ & $\mathbf{6 h}$ & $\mathbf{1 2 h}$ & $\mathbf{3 6 h}$ & $\mathbf{7 2 h}$ \\
\hline $\mathbf{2 2 7}$ & & $\mathrm{X}$ & $\mathrm{X}$ & $\mathrm{X}$ & $\mathrm{X}$ \\
$\mathbf{2 9 5}$ & & $\mathrm{X}$ & $\mathrm{X}$ & $\mathrm{X}$ \\
$\mathbf{2 7 9}$ & $\mathrm{X}$ & $\mathrm{X}$ & $\mathrm{X}$ & $\mathrm{X}$ & $\mathrm{X}$ \\
\hline *a letra "X" assinalando algumas colunas representa o intervalo de tempo em que o composto foi detectado.
\end{tabular}

Fonte: Autoria Própria.

Alguns fatores importantes devem ser observados, como o fato de os tempos de retenção dos compostos de $\mathrm{m} / z 295$ e 279 não terem mudado entre as análises em água e em efluente de reator. Além disso, o fato de conseguir extrair e identificar com êxito o fármaco inalterado através de MEPS permite uma monitorização eficiente da degradação biológica, caso esse seja o objetivo da análise. De fato, a pré-concentração por MEPS é muito pertinente para ser usada na extração de produtos biológicos, pois é relativamente rápida, usa pequenos volumes de amostra e de solventes e não necessita de outros aparatos, como bomba de vácuo. Assim, conforme alíquotas de efluente forem sendo retiradas do reator, já podem ser préconcentradas por MEPS, evitando que a reação biológica talvez continue. A Figura 12 mostra 
as bandas cromatográficas correspondentes aos espectros de massa dos compostos de $m / z 295$, 279 e 227.

Figura 12 - Produtos de degradação encontrados durante a biodegradação da SMZ obtidas a partir de análises realizadas por LC-QTOF (ESI (+) MS) após 72 horas de exposição ao reator anaeróbio. 1) Metabólito hidroxilado da SMZ; 2) SMZ inalterada e 3) conjugação com glicose.
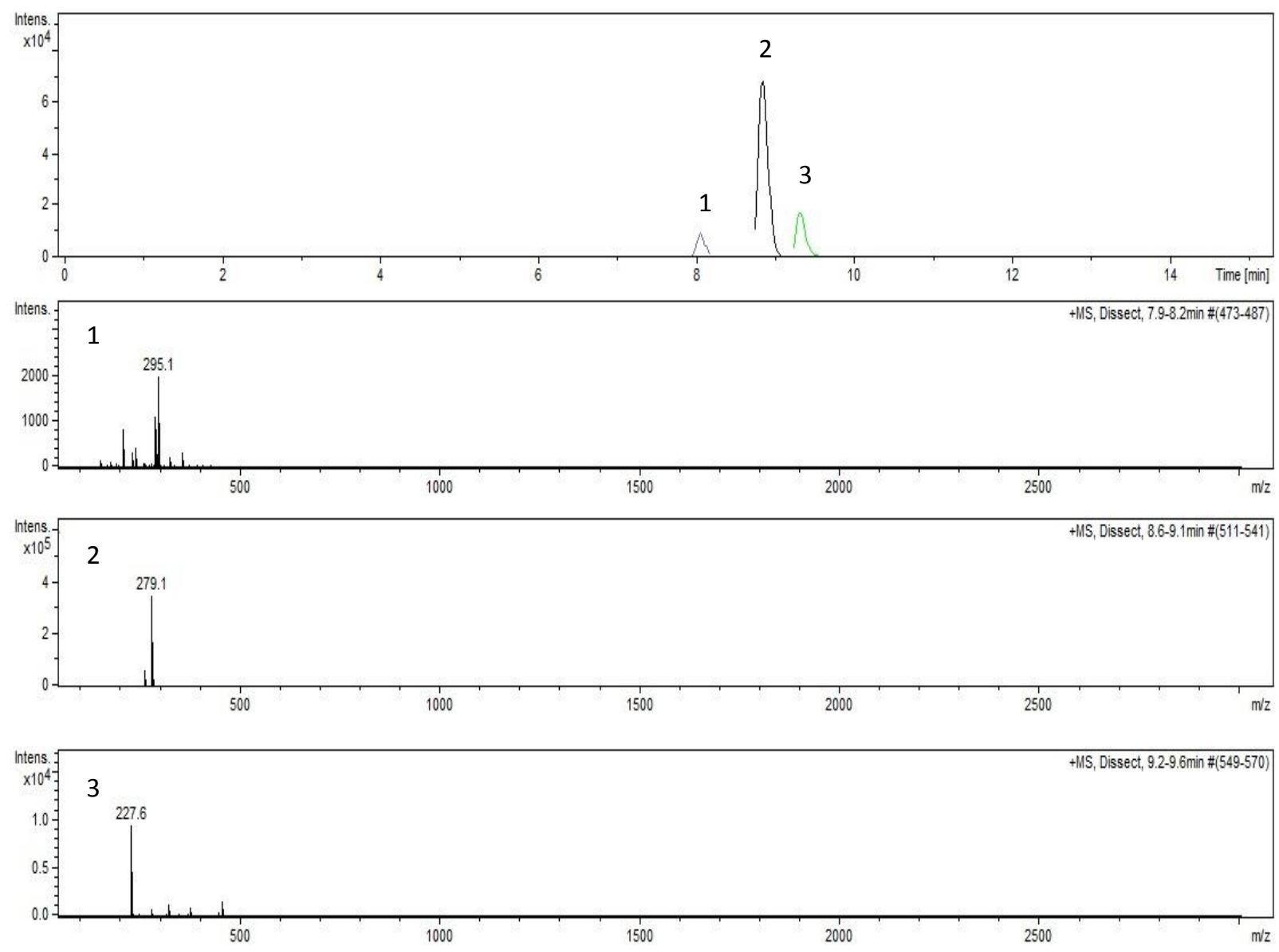

Fonte: FERREIRA, T. C. R., Tese de Doutorado, $2014^{65}$.

\subsection{Avaliação dos produtos de degradação formados durante a fotólise do ciprofloxacino na concentração de $10 \mathrm{mg} \mathrm{L}^{-1}$}

O ensaio fotoquímico foi realizado da mesma forma que com a sulfametazina, no reator de bancada (Figura 5) através da incidência de radiação UV-C mediante o uso de lâmpada de vapor de mercúrio $(9 \mathrm{~W})$. O ciprofloxacino foi completamente degradado com $2 \mathrm{~h}$ de exposição à radiação UV-C. Os produtos de degradação são formados durante a fotólise, em concentrações menores do que a da molécula inalterada. Todos os íons isolados e monitorados nesse experimento tiveram a sua identidade correlacionada à da molécula 
inalterada de ciprofloxacino, confirmada em espectros de massa de alta resolução e em espectrometria de massas sequencial, quando necessário, por Ferreira ${ }^{65}$. Como os produtos de degradação são formados em concentrações bem menores que a de fármaco inalterado, foi necessário usar uma concentração elevada $\left(10 \mathrm{mg} \mathrm{L}^{-1}\right)$ para identificar esses produtos. Para avaliar a capacidade de pré-concentração, inicialmente fez-se necessário o conhecimentos dos produtos de degradação formados durante a fotólise do CIP, por isso a utilização da concentração de $10 \mathrm{mg} \mathrm{L}^{-1}$.

Assim como na sulfametazina, houve um caso da relação massa carga se repetir, no produto $\mathrm{m} / \mathrm{z}$ 330A (TR 7,8 $\mathrm{min}$ ) e 330B (TR 10,7 $\mathrm{min}$ ). Os produtos produzidos em maior quatidade foram o $\mathrm{m} / \mathrm{z} 330 \mathrm{~A}$ e 346 (TR 8,6 min). Os seis produtos de degradação que aparecem em maior concentração sofrem a desfluoração da molécula de CIP. Apenas um produto de degradação $(\mathrm{m} / \mathrm{z} 316$, TR $10,1 \mathrm{~min})$ apresenta a abertura do ciclopropil presente na molécula inalterada de CIP.

Em um trabalho publicado por Gardinali e colaboradores ${ }^{69}$, a fotodegradação do ciprofloxacino em água foi feita utilizando um fotoreator de lâmpada de mercúrio (UV 254). A concentração inicial de fármaco inalterado foi de $1 \mathrm{mg} \mathrm{L}^{-1} \mathrm{e}$ as amostras foram analisadas por LC-ESI-IT/MS sem pré-concentração. Os autores relataram que o intermediário de $m / z 316$ foi observado em maior intensidade, seguido pelo $m / z$ 330. Os produtos de degradação identificados são semelhantes aos desse trabalho, variando apenas em concentração.

A maior intensidade dos intermediários foi observada aos 20 min de reação. Devido à sua baixa concentração, suas estruturas foram propostas a partir das fórmulas moleculares obtidas com o auxílio da ferramenta Smart Formula presente no software Data Analysis da Bruker.

A Tabela 15 mostra a estrutura química, a relação massa/carga e a fórmula molecular de cada produto de degradação do ciprofloxacino, bem como da molécula inalterada (m/z 332). 
Tabela 15 - Estruturas químicas, relações massa/carga $(\mathrm{m} / \mathrm{z})$ e fórmula molecular do ciprofloxacino e seus produtos de degradação

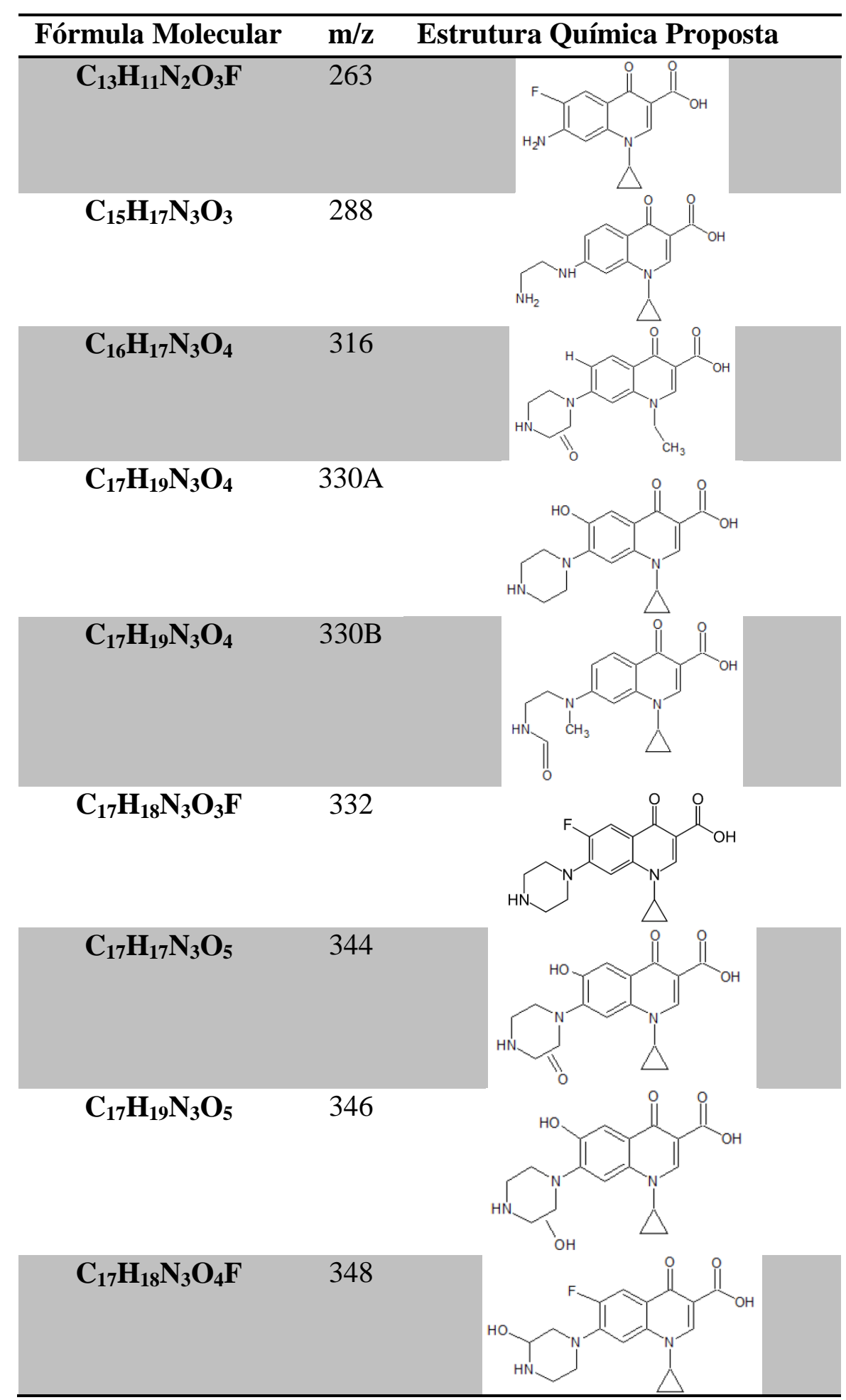

Fonte: Autoria própria, adaptado de FERREIRA, T. C. R., Tese de Doutorado, $2014^{65}$. 


\subsection{Pré-concentração dos produtos de degradação do ciprofloxacino, com diluição 1:20, em água}

Nas extrações dos intermediários do CIP, assim como na SMZ, foi utilizada uma seringa de $1000 \mu \mathrm{L}$. A fase extratora utilizada foi Oasis ${ }^{\circledR}$ HLB, da Waters, como especificado na seção 4.12. A eluição foi feita por etapas, com $25 \mu \mathrm{L}$ de acetonitrila acidificada com $5 \%$ de $\mathrm{H}_{3} \mathrm{PO}_{4}$ e $25 \mu \mathrm{L}$ de acetonitrila alcalinizada com $5 \%$ de $\mathrm{NH}_{4} \mathrm{OH}$, totalizando $50 \mu \mathrm{L}$. Os ciclos das etapas de MEPS foram as mesmas que para SMZ: 10 ciclos de condicionamento $(5$ com metanol puro e 5 com água em pH 3,4), 5 ciclos de extração de amostra e 20 ciclos de eluição (10 ciclos com acetonitrila acidificada com $5 \%$ de $\mathrm{H}_{3} \mathrm{PO}_{4}$ e 10 ciclos com acetonitrila alcalinizada com 5\% de $\mathrm{NH}_{4} \mathrm{OH}$ ). Dessa forma, foi feita recuperação a partir de diluição 1:20. A amostra não foi submetida à secagem, para evitar perdas na recuperação. $\mathrm{O}$ resultado da pré-concentração está apresentado na Tabela 16.

Tabela 16 - Pré-concentração dos produtos de degradação do ciprofloxacino em água, com diluição de 1:20

\begin{tabular}{ccc}
\hline $\mathbf{m} / \mathbf{z}$ & $\operatorname{Rec}(\boldsymbol{\%})$ & $\mathbf{C V}(\boldsymbol{\%})$ \\
\hline $\mathbf{2 6 3}$ & 114,30 & 7,69 \\
$\mathbf{2 8 8}$ & 38,65 & 12,46 \\
$\mathbf{3 1 6}$ & 101,87 & 7,95 \\
$\mathbf{3 3 0 A}$ & 44,26 & 9,25 \\
$\mathbf{3 3 0 B}$ & 115,24 & 10,21 \\
$\mathbf{3 3 2}$ & 99,54 & 13,05 \\
$\mathbf{3 4 4}$ & 119,83 & 6,64 \\
$\mathbf{3 4 6}$ & 106,75 & 9,28 \\
$\mathbf{3 4 8}$ & 118,03 & 23,99 \\
\hline a/carga; Rec=recuperação; CV=coeficiente de variação
\end{tabular}

Fonte: Autoria Própria.

* m/z=relação massa/carga; Rec=recuperação; $C V=$ coeficiente de variação

Os intermediários de $m / z$ 263, 330B, 344 e 348 apresentaram uma recuperação acima de $100 \%$. Essa discrepância deve-se à eluição com acetonitrila acidificada e alcalinizada, que pode aumentar consideravelmente a resposta desses intermediários. Os coeficientes de variação estão todos abaixo de $15 \%$, exceto para o produto de degradação de $m / z 348$. 


\subsection{Pré-concentração dos produtos de degradação do ciprofloxacino em baixa concentração}

Com o objetivo de aproximar as concentrações de trabalho das concentrações encontradas no meio ambiente, foram feitas degradações do ciprofloxacino em concentração mais baixa, na faixa de $0,10 \mathrm{mg} \mathrm{L}^{-1}$.

Foi utilizando reator de bancada (Figura 4) através da incidência de radiação UV-C mediante o uso de lâmpada de vapor de mercúrio $(9 \mathrm{~W})$, que degradou completamente o ciprofloxacino após 20 min (tempo utilizado para retirar as alíquotas na concentração de $10 \mathrm{mg} \mathrm{L}^{-1}$ ). O tempo de coleta das alíquotas foi de $10 \mathrm{~min}$. Novamente, os produtos de degradação formados durante a fotólise apresentam concentrações menores que a molécula inicial.

Como mostra a Figura 13, MEPS conseguiu extrair com êxito os produtos de degradação do ciprofloxacino produzidos diretamente em baixa concentração.

Figura 13 - Cromatograma do íon total referente à recuperação por MEPS dos produtos de degradação do ciproflxacino em baixa concentração $\left(0,10 \mathrm{mg} \mathrm{L}^{-1}\right)$. Em vermelho, produtos de degradação antes da extração. Em azul, produtos de degradação após a extração.

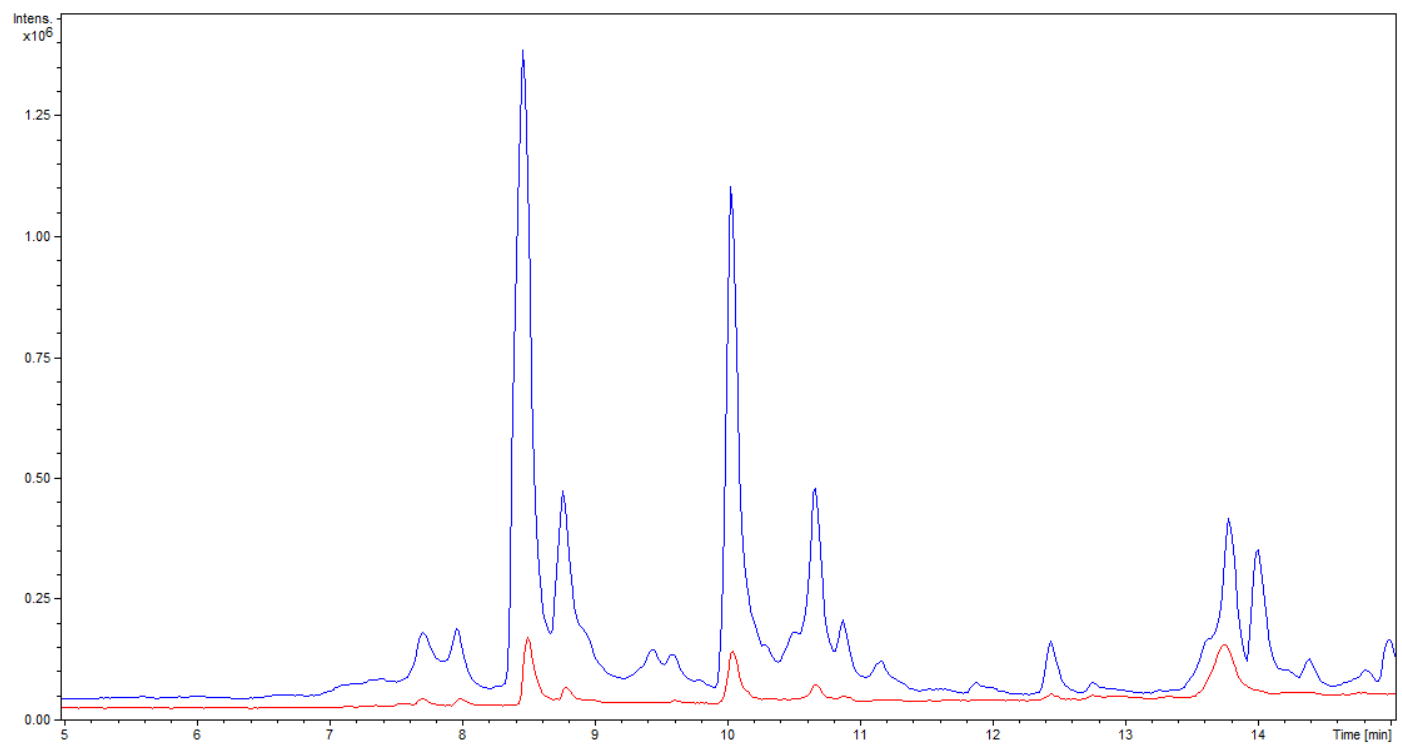

Fonte: Autoria Própria.

Foram identificados os mesmos oito produtos de degradação que foram identificados na degradação realizada em concentração elevada $\left(10 \mathrm{mg} \mathrm{L}^{-1}\right)$. O produto de degradação encontrado em maior intensidade é o $\mathrm{m} / z 346$ (TR 8,5 min), seguido por $\mathrm{m} / z 316$ 
(TR 10,1 min). A maioria dos produtos de degradação, por serem os mesmos da degradação em concentração mais elevada, apresentam a perda do átomo de flúor.

Os produtos de degradação de $m / z 263$ (TR 10,9 min) e 348 (TR 11,2 min) não foram identificados nas amostras que não foram submetidas à pré-concentração. Porém, após as amostras passarem por pré-concentração por MEPS, esses produtos de degradação foram identificados com êxito. Devido ao tempo de retenção dos analitos ser muito próximos, a ferramenta de deconvolução dos compostos apresentados no cromatograma, do software Data Analysis, da Bruker, foi esencial para a análise e interpretação dos dados.

Na comparação de MEPS com SPE, que foi desenvolvida na tese de Ferreira ${ }^{65}$, ambas as técnicas apresentaram desempenho semelhante na recuperação dos produtos de degradação, conseguindo recuperar todos os produtos de degradação do ciprofloxacino. É válido lembrar que, enquanto a SPE permite que sejam passados pelo cartucho de extração uma grande quantidade de amostra, MEPS utiliza um volume de amostra reduzido e limitado pelo volume da seringa, no caso desse trabalho, de apenas $1000 \mu \mathrm{L}$. A pré-concentração feita por essa técnica foi de vinte vezes. Valor baixo, se comparado aos valores que podem ser alcançados com a SPE. Dessa forma, conseguir pré-concentrar todos os produtos de degradação gerados em baixa concentração é realmente um resultado promissor para uma microtécnica de extração como MEPS.

\subsection{Pré-concentração dos produtos de degradação do ciprofloxacino, com diluição de 1:20 em esgoto sintético}

A extração dos intermediários de ciprofloxacino em esgoto sintético foi feita da mesma forma que em água, porém foi adicionada uma etapa de lavagem com água (3 ciclos) entre as etapas de extração da amostra e eluição, para eliminar possíveis interferentes presentes no meio, que prejudiquem a identificação dos compostos de interesse. A Tabela 17 mostra os resultados dessa pré-concentração.

Os produtos de degradação de relação m/z 288, 344 e 346 apresentaram grande diferença entre sua recuperação em água (Tabela 16) e em esgoto sintético (Tabela 17). Assim como no caso da SMZ, os produtos de degradação do CIP também devem sofrer a influência dos efeitos de matriz, tanto na extração quanto na detecção por espectrometria de $\operatorname{massas}^{53}$.

Com exceção dos produtos $\mathrm{m} / \mathrm{z}$ 330A e 346, todos os outros produtos apresentaram recuperação acima de $70 \%$. Os produtos de $\mathrm{m} / \mathrm{z}$ 263, 330B e 348 apresentaram valores de 
recuperação bem acima de $100 \%$ e esse resultado provavelmente é influenciado pelo efeito de matriz.

Tabela 17 - Pré-concentração dos produtos de degradação do ciprofloxacino em esgoto sintético, com diluição de 1:20

\begin{tabular}{ccc}
\hline $\mathbf{~ m} / \mathbf{z}$ & Rec $(\boldsymbol{\%})$ & $\mathbf{C V}(\boldsymbol{\%})$ \\
\hline $\mathbf{2 6 3}$ & 113,14 & 5,37 \\
$\mathbf{2 8 8}$ & 77,06 & 8,24 \\
$\mathbf{3 1 6}$ & 109,83 & 10,63 \\
$\mathbf{3 3 0 A}$ & 52,99 & 4,93 \\
$\mathbf{3 3 0 B}$ & 116,98 & 4,98 \\
$\mathbf{3 3 2}$ & 105,68 & 2,52 \\
$\mathbf{3 4 4}$ & 98,20 & 6,86 \\
$\mathbf{3 4 6}$ & 60,79 & 12,38 \\
$\mathbf{3 4 8}$ & 123,63 & 0,79 \\
\hline massa/carga; Rec=recuperação; CV=coeficiente de variação
\end{tabular}

Fonte: Autoria Própria.

* m/z=relação massa/carga; Rec=recuperação; CV=coeficiente de variação

\subsection{Pré-concentração dos produtos de degradação do ciprofloxacino em baixa concentração utilizando esgoto sintético como matriz}

As concentrações de fármacos encontradas no meio ambiente vêm crescendo progressivamente a cada ano, mas ainda assim, estão na ordem de ng $\mathrm{L}^{-1}$. Dessa forma, para aproximar-se progressivamente da concentração de uma amostra real, foi feita a fotólise do ciprofloxacino em baixa concentração $\left(0,10 \mathrm{mg} \mathrm{L}^{-1}\right)$ utilizando esgoto sintético como meio. A Figura 14 apresenta uma comparação entre uma alíquota que não passou por préconcentração (em vermelho) e uma alíquota que foi pré-concentrada por MEPS.

$\mathrm{Na}$ Figura 14, é possível notar que sem a pré-concentração (cromatograma em vermelho), os produtos de degradação estão em concentração baixíssima, não sendo possível distinguir bandas cromatográficas. A identificação foi feita somente com a ajuda do software Data Analysis, da Bruker. Os produtos de degradação de $m / z$ 263, 244 e 346 não foram identificados sem a pré-concentração. Porém, após passar pela pré-concentração (cromatograma azul), as bandas cromatográficas ficaram melhor delineadas, sendo mais facilmente identifica-las. Os produtos de degradação que não haviam sido identificados sem a pré-concentração, agora são encontrados.

Somente o produto de $m / z, 348$ que não foi identificado nem antes e nem após a préconcentração, o que sugere que ele não foi formado na degradação em baixa concentração 
diretamente em esgoto sintético ou que sua concentração foi muito baixa e o equipamento não teve suficiente detectabilidade.

Figura 14 - Cromatograma do íon total referente à recuperação por MEPS dos produtos de degradação do ciprofloxacino em baixa concentração $\left(0,10 \mathrm{mg} \mathrm{L}^{-1}\right)$ em esgoto sintético. Em vermelho, produtos de degradação que não passaram por extração. Em azul, produtos de degradação após a extração.

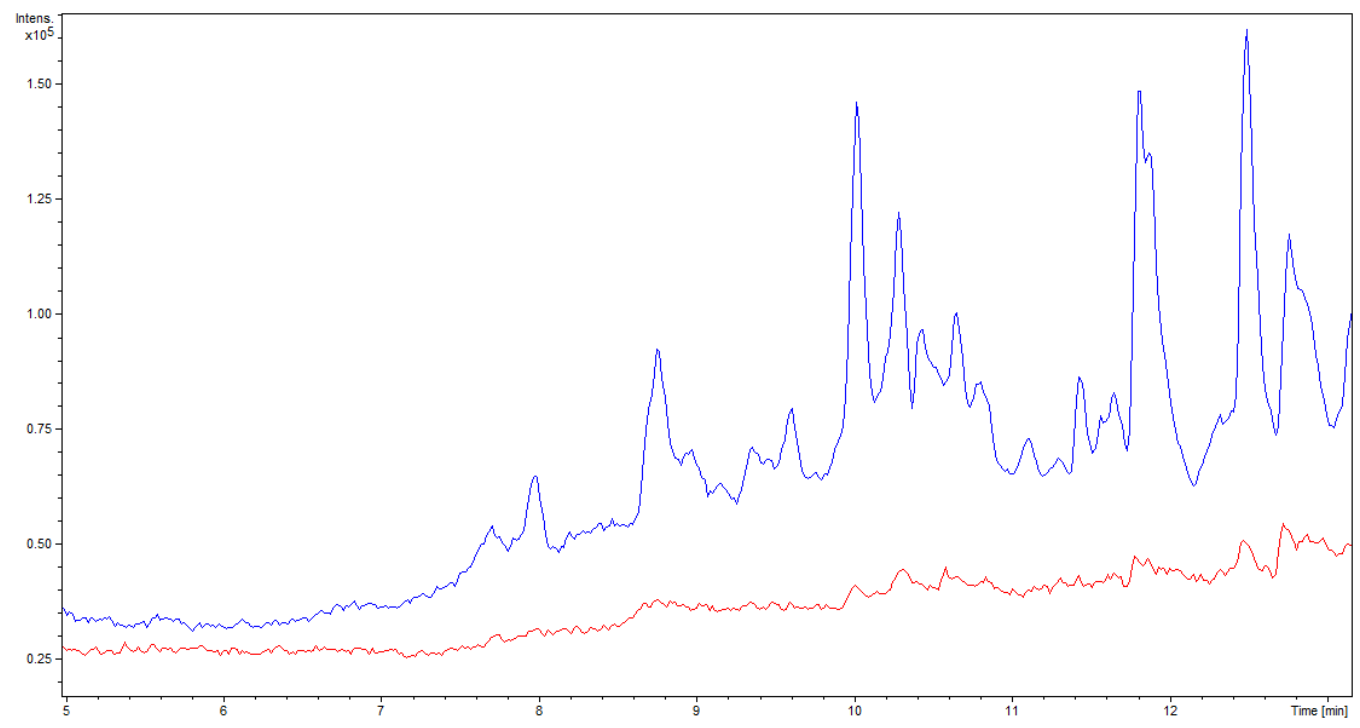

Fonte: Autoria Própria.

Mais uma vez os resultados mostram a importância de um preparo de amostra eficiente para a detecção de analitos em baixas concentrações. Produtos de degradação que não haviam sido detectados sem o preparo de amostra foram facilmente detectados após a préconcentração por MEPS. Comparando-se a degradação em baixa concentração do ciprofloxacino com a da sulfametazina (seção 4.7) é possível verificar que os cromatogramas do CIP tiveram maior ruído na linha de base, o que pode ser creditado ao efeito de matriz, que será estudado e discutido na seção 4.17. Também houve maior coeluição entre os produtos de degradação do ciprofloxacino, de forma que há maior dificuldade de encontrá-los no cromatograma sem o auxílio de software, como foi possível fazer com os produtos de degradação da sulfametazina.

\subsection{Estudos de efeitos de matriz na análise de produtos de degradação do ciprofloxacino}

Os estudos de efeito de matriz permitem ao analista ter maiores informações sobre o comportamento dos analitos de interesse na matriz em que eles são encontrados. Quanto mais 
complexa a matriz, ou seja, quanto maior a concentração e o número de compostos endógenos, mais provável que esses compostos venham a interferir e distanciar o resultado das análises do resultado real. Um preparo de amostra eficiente geralmente elimina grande parte dos efeitos de matriz, porém quanto maior o número de analitos de interesse, e também de compostos endógenos da matriz, mais difícil eliminar esses efeitos. O mais importante, contudo, é saber se esses efeitos existem e se eles aumentam ou diminuem o sinal dos analitos de interesse no espectrômetro de massas.

A Tabela 18 mostra os resultados dos estudos de efeito de matriz com o ciprofloxacino e seus produtos de degradação, de acordo com adaptações do protocolo de Matuszewski $^{54}$.

Tabela 18 - Efeito de matriz, recuperação e eficiência do processo para produtos de degradação do ciprofloxacino em esgoto sintético

\begin{tabular}{cccc}
\hline $\mathbf{m} / \mathbf{z}$ & ME (\%) & RE $(\boldsymbol{\%})$ & PE $(\boldsymbol{\%})$ \\
\hline $\mathbf{2 6 3}$ & 148,32 & 110,57 & 163,99 \\
$\mathbf{2 8 8}$ & 489,05 & 65,71 & 321,38 \\
$\mathbf{3 1 6}$ & 143,13 & 92,89 & 132,95 \\
$\mathbf{3 3 0 A}$ & 199,50 & 58,10 & 115,91 \\
$\mathbf{3 3 0 B}$ & 113,90 & 107,29 & 122,21 \\
$\mathbf{3 3 2}$ & 185,01 & 113,88 & 210,69 \\
$\mathbf{3 4 4}$ & 128,25 & 92,32 & 118,40 \\
$\mathbf{3 4 6}$ & 207,95 & 118,11 & 245,61 \\
$\mathbf{3 4 8}$ & 130,17 & 116,34 & 151,44
\end{tabular}

* m/z=relação massa/carga; ME=efeito de matriz; RE=recuperação; PE=eficiência total do processo Fonte: Autoria Própria.

De acordo com os resultados mostrados na Tabela 18, todos os produtos de degradação do ciprofloxacino e o fármaco inalterado sofrem efeito de matriz de maneira pronunciada. Para que um composto não sofra efeito de matriz (pelo menos numericamente) seu valor em porcentagem na coluna ME da Tabela 18 deve ser cem. Considerando que todos os compostos obtiveram valores maiores que cem, pode-se dizer que há um efeito generalizado de aumento de sinal dos analitos de interesse no espectrômetro de massas causado pelos interferentes da matriz.

Dentre os analitos, aquele que sofre maior efeito de matriz é o de $\mathrm{m} / \mathrm{z} 288$, que apresenta uma grande discrepância de valor em relação aos outros analitos. Os analitos de 
$m / z$ 346, 300A e 332 também apresentaram valores bastante altos para efeito de matriz. O analito que sofre menor influência é o de $\mathrm{m} / \mathrm{z}$ 330B.

Os resultados obtidos são bastante interessantes se comparados com os cromatogramas da seção 4.16, na qual já foi comentado que os ruídos na linha de base talvez fossem devidos ao efeito de matriz. $\mathrm{O}$ fato de os estudos de efeito de matriz terem mostrado que os produtos de degradação do ciprofloxacino sofrem grande influência dos interferentes presentes no esgoto sintético, explica parcialmente a presença de ruídos na linha de base, bem como a coeluição dos compostos. Diz-se parcialmente, pois para afirmações mais categóricas são necessários maiores estudos acerca do assunto. Porém, esses estudos mais aprofundados geralmente barram no fato de que não há padrões analíticos de alta pureza para os produtos de degradação.

No caso da sulfametazina (seção 4.8), os produtos de degradação sofreram tanto efeitos de supressão quanto de aumento de sinal. Há diferenças importantes entre os métodos de extração e as moléculas geradas pela degradação da sulfametazina e do ciprofloxacino. Com a sulfametazina, as moléculas formadas pela fotodegradação são mais leves e menores. Nenhuma massa ultrapassa 295 u (unidades de massa atômica) e o solvente utilizado para eluição é o metanol, um solvente prótico, que pode ter interagido de alguma forma com os analitos e os interferentes. Já no caso do ciprofloxacino, as moléculas geradas pela fotodegradação têm massas maiores, que vão de 263 até 348 u e o solvente utilizado na eluição foi a acetonitrila, um solvete aprótico. Também há o fato de terem sido utilizados solventes alcalinizados (caso da SMZ e do CIP) e acidificados (caso do CIP) para a eluição. Tais afirmações precisam ser melhores exploradas em estudos futuros, pois geram discussões interessantes e que podem acrescentar no estudo de produtos de degradação, que ainda é um campo bastante obscuro da química analítica.

É importante frisar que a matriz utilizada para os estudos desta seção foi o esgoto sintético, devido à disponibilidade e à relação com os reatores biológicos desenvolvidos pelos alunos do LPB/Prof. Zaiat. Dessa forma, vale observar que cada vez que a matriz em questão for mudada, esses estudos deverão ser refeitos.

\subsection{Pré-concentração dos produtos de degradação do ciprofloxacino utilizando nanotubos de carbono como fase extratora}

A utilização dos nanotubos de carbono já foi justificada anteriormente nesse trabalho. Sua grande área superficial e poder de adsorção os tornam candidatos promissores a fase extratora. Porém, no caso da sulfametazina (seção 4.9), nem o solvente de eluição mais 
potente foi capaz de retirar os analitos de interesse da fase extratora. $\mathrm{Na}$ Tabela 19 é mostrado o comportamento dos produtos de degradação do ciprofloxacino, bem como do fármaco inalterado, ante os nanotubos de carbono como fase extratora.

Tabela 19 - Pré-concentração dos produtos de degradação de ciprofloxacino utilizando nanotubos de carbono como fase extratora, com diluição 1:20

\begin{tabular}{ccc}
\hline $\mathbf{m} / \mathbf{z}$ & $\operatorname{Rec}(\boldsymbol{\%})$ & $\mathbf{C V}(\boldsymbol{\%})$ \\
\hline $\mathbf{2 8 8}$ & 40,42 & 21,36 \\
$\mathbf{3 1 6}$ & 57,20 & 20,14 \\
$\mathbf{3 3 0 A}$ & 13,22 & 9,35 \\
$\mathbf{3 3 0 B}$ & 57,03 & 15,86 \\
$\mathbf{3 3 2}$ & 24,81 & 27,70 \\
$\mathbf{3 4 4}$ & 44,73 & 15,84 \\
$\mathbf{3 4 6}$ & 20,17 & 34,54 \\
$\mathbf{3 4 8}$ & 68,28 & 11,75 \\
\hline
\end{tabular}

* m/z=relação massa/carga; Rec=recuperação; $\mathrm{CV}=$ coeficiente de variação

Fonte: Autoria Própria.

Os valores mostrados na Tabela 19 estão consideravelmente abaixo daqueles mostrados na Tabela 16, na qual a fase extratora é Oasis ${ }^{\circledR}$ HLB. Os valores de coeficiente de variação também estão maiores, alguns bem acima de 20\%. O produto de $\mathrm{m} / \mathrm{z} 263$ não foi identificado após a pré-concentração utilizando nanotubos como fase extratora. Provavelmente o mesmo fato que ocorreu com a sulfametazina também ocorreu com o ciprofloxacino: os analitos ficaram retidos na fase móvel e o solvente não conseguiu eluí-los com eficiência. A Figura 15 ajuda a discutir se tal fato ocorreu, comparando cromatogramas de uma amostra dos produtos de degradação do ciprofloxacino que não foi submetida à extração, uma amostra que passou pela extração com nanotubos de carbono como fase extratora, amostra residual (matriz) após passar pelo dispositivo de extração e uma injeção após lavar a fase extratora com metanol puro.

A Figura 15 permite concluir que os analitos de interesse ficaram retidos na fase extratora mesmo após a eluição. O cromatograma em vermelho, da amostra sem préconcentração, apresenta bandas cromatográficas definidas dos produtos de degradação. Já no cromatograma azul, após a pré-concentração, as bandas cromatográficas dos analitos apresentam uma intensidade bem menor. O cromatograma em magenta, que representa a matriz residual da pré-concentração, não apresenta bandas cromatográficas que correspondem aos analitos de interesse. E o cromatograma em verde, representante da injeção após lavagem 
da fase extratora também não apresentou bandas cromatográficas relativas aos analitos de interesse.

Figura 15 - Cromatograma do íon total referente à recuperação por MEPS dos produtos de degradação do ciprofloxacino em alta concentração $\left(10 \mathrm{mg} \mathrm{L}^{-1}\right)$ em água, utilizando nanotubos de carbono como fase extratora. Em vermelho, produtos de degradação que não passaram por extração. Em magenta, alíquota residual após passar por extração. Em azul, produtos de degradação após a extração. Em verde, fase extratora após lavagem.

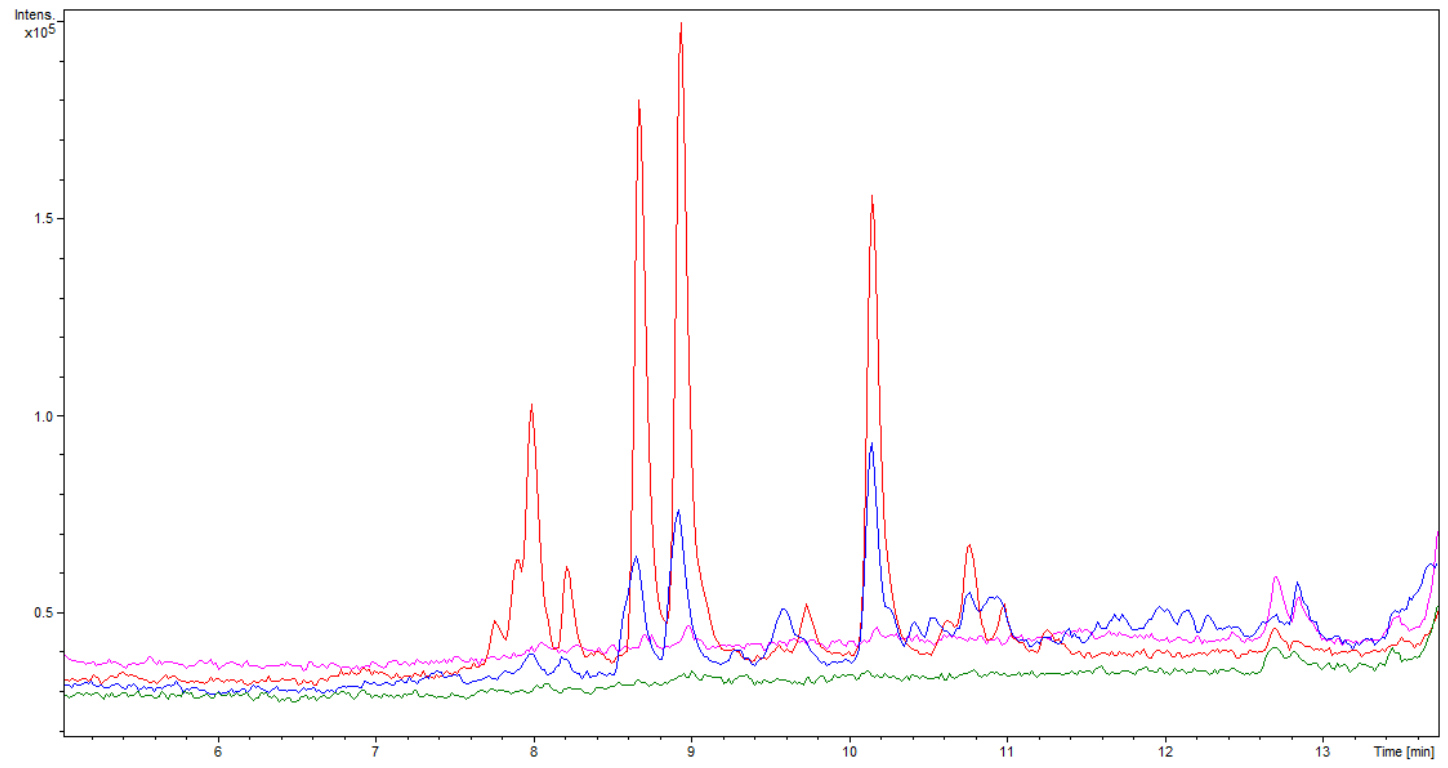

Fonte: Autoria Própria.

Mais uma vez, mesmo após a eluição com o solvente ideal para a fase Oasis ${ }^{\circledR}$ HLB e após a lavagem da fase extratora, os analitos ficaram retidos nos nanotubos de carbono, que apesar de serem promissores como fase extratora, não apresentaram bons resultados para os produtos de degradação do ciprofloxacino nem da sulfametazina. 


\section{CONCLUSÕES}

- Os produtos de degradação podem não ter grande similaridade com os fármacos inalterados e geralmente são mais polares que as moléculas de origem;

- Na fotodegradação, os produtos de degradação são formados em concentrações consideravelmente mais baixas que a solução padrão do fármaco de origem;

- Para a sulfametazina foram gerados seis produtos de degradação além da molécula inalterada. Em baixa concentração, mais um produto foi gerado e detectado;

- Para o ciprofloxacino, foram gerados oito produtos de degradação, além do fármaco inalterado, tanto em alta quanto em baixa concentração;

- Os nanotubos de carbono não obtiveram altas taxas de recuperação, pois os produtos de degradação (tanto da sulfametazina quanto do ciprofloxacino) ficaram fortemente retidos e o eluente empregado não foi eficiente em solubilizá-los e arrastá-los. Para próximos trabalhos, a utilização de nanotubos funcionalizados talvez seja mais eficiente;

- O etanol obteve boas taxas de recuperação para os produtos de degradação da sulfametazina. Sua eficiência foi menor que a do metanol, mas ainda assim é uma alternativa a ser explorada em trabalhos futuros;

- A utilização de MEPS como técnica de extração foi bastante eficiente, considerando-se as diferenças estruturais entre os analitos. Tanto em água purificada quanto em esgoto sintético, as taxas de recuperação foram relativamente altas e permitiram a perfeita identificação dos produtos de degradação;

- Em baixas concentrações, MEPS também foi eficiente e pré-concentrou produtos de degradação que estavam em concentração muito baixa para serem identificados antes da extração;

- MEPS também foi eficiente em extrair produtos de degradação biológica presentes em efluentes de um reator anaeróbio. Esse resultado é bastante expressivo, principalmente se for 
considerada a possibilidade de utilizar-se MEPS como técnica de extração para acompanhar a degradação biológica do reator em função do tempo;

- Os estudos de efeito de matriz mostraram que a maioria dos produtos de degradação sofre uma ampliação de sinal quando extraídos de matrizes mais complexas, como o esgoto sintético. Para futura quantificação, seria necessária a obtenção de padrões analíticos e eventualmente o uso do método de adições de padrão, ou, no mínimo a compatibilização da matriz (matrix match);

- Considerando-se todos esses fatores, MEPS apresenta-se como uma técnica promissora para a pré-concentração de produtos de degradação. Suas taxas de recuperação são relativamente altas (acima de 50\%) e os coeficientes de variação ficam, geralmente, abaixo de 15\%, o que é aceitável para amostras com baixas concentrações. Como a técnica requer somente a seringa com o dispositivo de extração e pequena quantidade de solventes, pode ser feita in loco, o que evita degradações e modificações na amostra. É uma alternativa promissora para análises feitas em rios, aquíferos e ETE's, pois não requer instalações como vácuo e nitrogênio. 


\section{REFERÊNCIAS BIBLIOGRÁFICAS}

[1] STUMPF, M.; TERNES, T. A.; WILKEN, R. D.; RODRIGUES, S. V.; BAUMANN, W. Polar drug residues in sewage and natural waters in the state of Rio de Janeiro, Brazil. Science of the Total Environment, v. 225, n. 1-2, p. 135-141, 1999.

[2] TERNES, T. A. Occurrence of drugs in German sewage treatment plants and rivers. Water Research, v. 32, n.11, p. 3245-3260, 1998.

[3] TERNES, T. A.; STUMPF, M.; MUELLER, J.; HABERER, K.; WILKEN, R. D.; SERVOS, M. Behavior and occurrence of estrogens in municipal sewage treatment plants - I. Investigations in Germany, Canada and Brazil. Science of the Total Environment, v. 225, n. 1-2, p. 81-90, 1999.

[4] KUMMERER, K. Drugs in the environment: emission of drugs, diagnostic aids and disinfectants into wastewater by hospitals in relation to other sources - a review.

Chemosphere, v. 45, n. 6-7, p. 957-969, 2001.

[5] BOWER, C. K.; DAESCHEL, M. A. Resistance responses of microorganisms in food environments. International Journal of Food Microbiology, v. 50, n.1-2, p. 33-44, 1999.

[6] GUARDABASSI, L.; WONG, D. M. A. L.; DALSGAARD, A. The effects of tertiary wastewater treatment on the prevalence of antimicrobial resistant bacteria. Water Research, v. 36, n. 8, p. 1955-1964, 2002.

[7] GUILLEMOT, D. Antibiotic use in humans and bacterial resistance. Current Opinion in Microbiology, v. 2, n. 5, p. 494-498, 1999.

[8] MCKEON, D. M.; CALABRESE, J. P.; BISSONNETTE, G. K. Antibiotic-Resistant Gram-Negative Bacteria in Rural Groundwater Supplies. Water Research, v. 29, n. 8, p. 1902-1908, 1995.

[9] MIRANDA, C. D.; CASTILLO, G. Resistance to antibiotic and heavy metals of motile aeromonads from Chilean freshwater. Science of the Total Environment, v. 224, n. 1-4, p. 167-176, 1998.

[10] INGERSLEV, F.; TORANG, L.; LOKE, M. L.; HALLING-SORENSEN, B.; NYHOLM, N. Primary biodegradation of veterinary antibiotics in aerobic and anaerobic surface water simulation systems. Chemosphere, v. 44, n. 4, p. 865-872, 2001.

[11] LOKE, M. L.; INGERSLEV, F.; HALLING-SORENSEN, B.; TJORNELUND, J. Stability of Tylosin A in manure containing test systems determined by high performance liquid chromatography. Chemosphere, v. 40, n. 7, p. 759-765, 2000.

[12] RABOLLE, M.; SPLIID, N. H. Sorption and mobility of metronidazole, olaquindox, oxytetracycline and tylosin in soil. Chemosphere, v. 40, n. 7, p. 715-722, 2000.

[13] BARCELÓ, D.; FARRÉ, M. Analysis of emerging contaminants in food. Trends in Analytical Chemistry, v. 43, p. 240-253, 2013. 
[14] HIRSCH, R.; TERNES, T. A.; HABERER, K.; MEHLICH, A.; BALLWANZ, F.; KRATZ, K. L. Determination of antibiotics in different water compartments via liquid chromatography electrospray tandem mass spectrometry. Journal of Chromatography A, v. 815, n. 2, p. 213-223, 1998.

[15] SACHER, F.; LANG, F. T.; BRAUCH, H. J.; BLANKENHORN, I. Pharmaceuticals in groundwaters - Analytical methods and results of a monitoring program in BadenWurttemberg, Germany. Journal of Chromatography A, v. 938, n. 1-2, p. 199-210, 2001.

[16] TERNES, T.; BONERZ, M.; SCHMIDT, T. Determination of neutral pharmaceuticals in wastewater and rivers by liquid chromatography-electrospray tandem mass spectrometry. Journal of Chromatography A, v. 938, n. 1-2, p. 175-185, 2001.

[17] LOCATELLI, M. A. F.; SODRE, F. F.; JARDIM, W. F. Determination of Antibiotics in Brazilian Surface Waters Using Liquid Chromatography-Electrospray Tandem Mass Spectrometry. Archives of Environmental Contamination and Toxicology, v. 60, n. 3, p. 385-393, 2011.

[18] DEBLONDE, T.; COSSU-LEGUILLE, C.; HARTEMANN, P. Emerging pollutants in wastewater: A review of the literature. International Journal of Hygiene and Environmental Health, v. 214, n. 6, p. 442-448, 2011.

[19] DE SOUZA, M. V. N.; VASCONCELOS, T. R. A. Drugs against tuberculose: Past, present and future. Química Nova, v. 28, n. 4, p. 678-682, 2005.

[20] SOUZA, Isabel Cristina. Interacção da Enrofloxacina com modelos biomembranares: Influência das suas propriedades físico-químicas. 2007. $107 \mathrm{f}$. Dissertação (Mestrado em Tecnologia, Ciência e Segurança Alimentar)- Departamento de Química, Faculdade de Ciências da Universidade do Porto, Lisboa, 2007.

[21] PARK, H-R.; KIM, T. H.; BARK, K-M. Physicochemical properties of quinolone antibiotics in various environments. European Journal of Medicinal Chemistry, v. 37, n.6, p. 443-460, 2002.

[22] MERCOLA, J. Antibiotic Alert: The Drug the Doctor Ordered Could Cause Deadly Side Effects. Schaumburg, 2012. Disponível em: < http://articles.mercola.com/sites/articles/archive/2012/10/20/fluoroquinolones-sideeffects.aspx>. Acesso em: 20 dez. 2014.

[23] U.S. FOOD AND DRUG ADMINISTRATION. FDA Drug Safety Communication: FDA requires label changes to warn of risk for possibly permanent nerve damage from antibacterial fluoroquinolone drugs taken by mouth or by injection. Silver Spring, 2013. Disponível em: < http://www.fda.gov/Drugs/DrugSafety/ucm365050.htm>. Acesso em: 20 dez. 2014.

[24] ETMINAN, M.; FOROOGHIAN, F.; BROPHY, J. M.; BIRD, S. T.; MABERLEY, D. Oral Fluoroquinolones and the Risk of Retinal Detachment. The Journal of American Medical Association, v. 307, n. 13, p. 1414-1419, 2012. 
[25] YANG, L.; ETMINAN, M.; MIKELBERG, F. S. Oral fluoroquinolones and risk of glaucoma. Journal of Glaucoma, v. 23, n. 7, p. 464-466, 2014.

[26] GRANDJEAN, P.; LANDRIGAN, P. J. Neurobehavioural effects of developmental toxicity. The Lancet Neurology, v. 13, n. 3, p. 330-338, 2014.

[27] TORNIAINEN, K.; TAMMILEHTO, S.; ULVI, V. The effect of pH, buffer type and drug concentration on the photodegradation of ciprofloxacin. International Journal of Pharmaceutics, v.132, n. 1-2, p. 53-61, 1996.

[28] HOFF, R. B.; MENEGHINI, L.; PIZZOLATO, T. M.; PERALBA, M. C. R.; DÍAZCRUZ, M. S.; BARCELÓ, D. Structural Elucidation of Sulfaquinoxaline Metabolism Products and Their Occurrence in Biological Samples Using High-Resolution Orbitrap Mass Spectrometry. Analytical Chemistry, v. 86, n. 11, p. 5579-5586, 2014.

[29] BIALK, H. M.; SIMPSON, A. J.; PEDERSEN, J. A. Cross-coupling of sulfonamide antimicrobial agents with model humic constituents. Environmental Science \& Technology, v. 39, n. 12, p. 4463-4473, 2005.

[30] ALEXY, R.; KUMPEL, T.; KUMMERER, K. Assessment of degradation of 18 antibiotics in the Closed Bottle Test. Chemosphere, v. 57, n. 6, p. 505-512, 2004.

[31] LIN, T.; CHEN, Y.; CHEN, W. Impact of toxicological properties of sulfonamides on the growth of zebrafish embryos in the water. Environmental Toxicology and Pharmacology, v. 36, n. 3, p. 1068-1076, 2013.

[32] MARQUES, B. Sulfonamidas. Pork World, v. 59, n. 10, p. 82-85, 2010.

[33] LAPWORTHA, D. J.; BARANB, N.; STUARTA, M. E.; WARDA R. S. Emerging organic contaminants in groundwater: A review of sources, fate and occurrence. Environmental Pollution, v. 163, p. 287-303, 2012.

[34] TOLLS, J. Sorption of veterinary pharmaceuticals in soils: A review. Environmental Science and Technology, v. 35, n. 17, p. 3397-3406, 2001.

[35] BATT, A. L.; BRUCE, I. B.; AGA, D. S. Evaluating the vulnerability of surface waters to antibiotic contamination from varying wastewater treatment plant discharges.

Environmental Pollution, v. 142, n. 2, p. 295-302, 2006.

[36] LE-MINH, N.; KHAN, S. J.; DREWES, J. E.; STUETZ, R. M. Fate of antibiotics during municipal water recycling treatment processes. Water Research, v. 44, n. 15, p. 42954323, 2010.

[37] CALISTO, V.; ESTEVES, V. I. Psychiatric pharmaceuticals in the environment. Chemosphere, v. 77, n. 10, p. 1257-1274, 2009.

[38] RIZZO, L.; MANAIA, C.; MERLIN, C.; SCHWARTZ, T.; DAGOT, C.; PLOY, M. C.; MICHAEL, I.; FATTA-KASSINOS, D. Urban wastewater treatment plants as hotspots for antibiotic resistant bacteria and genes spread into the environment: A review. Science of The Total Environment, v. 447, n. 1, p. 345-360, 2013. 
[39] AGUERA, A.; ESTRADA, L. A. P.; FERRER, I.; THURMAN, E. M.; MALATO, S.; FERNANDEZ-ALBA, A. R. Application of time-of-flight mass spectrometry to the analysis of phototransformation products of diclofenac in water under natural sunlight. Journal of Mass Spectrometry, v. 40, n. 7, p. 908-915, 2005.

[40] LANÇAS, F. M. Cromatografia líquida moderna - HPLC/CLAE. Campinas: Átomo Editora, 2009. 384 p.

[41] PAWLISZYN, J. Theory of solid-phase microextraction. Journal of Chromatographic Science, v. 38, n. 7, p. 270-278, 2000.

[42] ABDEL-REHIM, M. Recent advances in microextraction by packed sorbent for bioanalysis. Journal of Chromatography A, v. 1217, n. 16, p. 2569-2580, 2010.

[43] ABDEL-REHIM, M. Current Advances in Microextraction by Packed Sorbent (MEPS) for Bioanalysis Applications. LC-GC Europe, v. 22, p.8-18, 2009.

[44] ALTUN, Z.; ABDEL-REHIM, M. Study of the factors affecting the performance of microextraction by packed sorbent (MEPS) using liquid scintillation counter and liquid chromatography-tandem mass spectrometry. Analytica Chimica Acta, v. 630, n. 2, p. 116-123, 2008.

[45] ABDEL-REHIM, M. New trend in sample preparation: on-line microextraction in packed syringe for liquid and gas chromatography applications I. Determination of local anaesthetics in human plasma samples using gas chromatography-mass spectrometry. Journal of Chromatography B, v. 801, n. 2, p. 317-321, 2004.

[46] NIESSEN, W. M. A. State-of-the-art in liquid chromatography-mass spectrometry. Journal of Chromatography A, v. 856, n. 1-2, p. 179-197, 1999.

[47] CHIARADIA, M. C.; COLLINS, C. H.; JARDIM, I. C. S. F. O estado da arte da cromatografia associada à espectrometria de massas acoplada à espectrometria de massas na análise de compostos tóxicos em alimentos. Química Nova, v. 31, n. 3, p. 623-636, 2008.

[48] KEBARLE, P. A brief overview of the present status of the mechanisms involved in electrospray mass spectrometry. Journal of Mass Spectrometry, v. 35, n. 7, p. 804-817, 2000.

[49] HOFFMANN, E.; STROOBANT, V. Mass Spectrometry: Principles and Applications Chichester: John Wiley and Sons, 2007. 489 p.

[50] TAYLOR, P.J. Matrix effects: The Achilles heel of quantitative high-performance liquid chromatography-electrospray-tandem mass spectrometry. Clinical Biochemistry, v. 38, n. 4, p. 328-334, 2005.

[51] KING, R.; BONFIGLIO, R.; FERNANDEZ-METZLER, C.; MILLER-STEIN, C.; OLAH, T. Mechanistic investigation of ionization suppression in electrospray ionization. Journal of the American Society for Mass Spectrometry, v.11, n. 11, p. 942-950, 2000. 
[52] BONFIGLIO, R.; KING, R.C.; OLAH, T.V.; MERKLE, K. The effects of sample preparation methods on the variability of the electrospray ionization response for model drug compounds. Rapid Communications in Mass Spectrometry, v. 13, n. 12, p. 1175$1185,1999$.

[53] KLOEPFER, A.; QUINTANA, J.B.; REEMTSMA, T. Operational options to reduce matrix effects in liquid chromatography- electrospray ionization-mass spectrometry analysis of aqueous environmental samples. Journal of Chromatography A, v. 1067, n. 1-2, p.153-160, 2005.

[54] MATUSZEWSKI, B.K.; CONSTANZER, M.L.; CHAVEZ-ENG, C.M. Strategies for the assessment of matrix effect in quantitative bioanalytical methods based on HPLCMS/MS. Analytical Chemistry, v. 75, n. 13, p. 3019-3030, 2003.

[55] HOFF, R. B.; RÜBENSAM, G.; JANK, L.; BARRETO, F.; PERALBA, M. C. R.; PIZZOLATO, T. M.; DÍAZ-CRUZ, M. S.; BARCELÓ, D. Analytical quality assurance in veterinary drug residue analysis methods: Matrix effects determination and monitoring for sulfonamides analysis. Talanta, v.132, n. 15, p. 443-450, 2015.

[56] CHONGA, M. N.; JINA, B.; CHOW, C. W. K.; SAINT, C. Recent developments in photocatalytic water treatment technology: A review. Water Research, v. 44, n. 10, p. 2997-3027, 2010.

[57] PERA-TITUS, M.; GARCÍA-MOLINA, V.; BAÑOS, M. A.; GIMÉNEZ, J.; ESPLUGAS, S. Degradation of chlorophenols by means of advanced oxidation processes: a general review. Applied Catalysis B: Environmental, v. 47, n. 4, p. 219-256, 2004.

[58] PHILLIPS, R. Sources and applications of ultraviolet radiation. New York: Academic Press, 1983.434p.

[59] DINIZ, M. S.; SALGADO, R.; PEREIRA, V. J.; CARVALHO, G.; OEHMEN, A.; REIS, M. A.; NORONHA, J. P. Ecotoxicity of ketoprofen, diclofenac, atenolol and their photolysis byproducts in zebrafish (Danio rerio). Science of the Total Environment, v. 505, n. 1, p. 282-289, 2015.

[60] LETTINGA, G. Anaerobic digestion and wastewater treatment systems. Antonie van Leeuwenhoek, International Journal of General and Molecular Microbiology, v. 67, n. 1, p. 3-28, 1995.

[61] HENZE, M.; HARREMOES, P. Anaerobic treatment of wastewater in fixed film reactors - A literature review. Water Science and Technology, v. 15, n. 8-9, p. 1-101, 1983.

[62] DE ZEEUW, W.J.; LETTINGA, G. Use of anaerobic digestion for wastewater treatment. Antonie van Leeuwenhoek, International Journal of General and Molecular Microbiology, v. 46, n. 1, p. 110-112, 1980. 
[63] FRANCO-RIVERA, A.; PANIAGUA-MICHEL, J.; ZAMORA-CASTRO, J. Characterization and performance of constructed nitrifying biofilms during nitrogen bioremediation of a wastewater effluent. Journal of Industrial Microbiology and Biotechnology, v. 34, n. 4, p. 279-287, 2007.

[64] SANTOS-NETO, A. J.; LANCAS, F. M.; CONTADORI, A.; ORTEGA, S. N.; AMPARO, M. R. Microdispositivo de extração desmontável para adaptação a microsseringas de agulha removível. BR1020130254517, 02 out. 2013.

[65] FERREIRA, Tanare Cambraia Ribeiro. Identificação e pré-concentração dos produtos da fotodegradação de antimicrobianos. 2014. $147 \mathrm{f}$. Tese (Doutorado em Química)- Instituto de Química de São Carlos, Universidade de São Paulo, São Carlos, 2014.

[66] TORRES, P. Desempenho de um reator anaeróbio de manta de lodo (UASB) de bancada no tratamento de substrato sintético simulando esgoto sanitário sob diferentes condições de operação. 1992. 185 p. Dissertação (Mestrado em Hidráulica e Saneamento) - Escola de Engenharia de São Carlos, Universidade de São Paulo, São Carlos, 1992.

[67] TRIBURTIUS E. R. L.; PERALTA-ZAMORA, P. Contaminação de águas por BTXs e processos utilizados na remediação de sítios contaminados. Química Nova, v. 27, n. 3, p. 441-446, 2004.

[68] GARCÍA-GALÁN, M. J.; DÍAZ-CRUZ, M. S.; BARCELÓ, D. Kinetic studies and characterization of photolytic products of sulfamethazine, sulfapyridine and their acetylated metabolites in water under simulated solar irradiation. Water research, v. 46, n. 3, p. 711-722, 2012.

[69] RANI, S.; PANDITI, V.R.; SHEA, K.E.O.; GARDINALI, P.R. Photodegradation of antibiotics under simulated solar radiation: Implications for their environmental fate. Science of the Total Environment, v. 471, p. 299-310, 2014. 